\title{
Hoe oud-studenten van de Universiteit Maastricht hun curricula evalueren : tweede fase van het project 'curriculumevaluatie in het licht van de beroepspraktijk'
}

Citation for published version (APA):

Ramaekers, G. W. M. (2004). Hoe oud-studenten van de Universiteit Maastricht hun curricula evalueren : tweede fase van het project 'curriculumevaluatie in het licht van de beroepspraktijk'. Researchcentrum voor Onderwijs en Arbeidsmarkt, Faculteit der Economische Wetenschappen. ROA Reports No. 7 https://doi.org/10.26481/umarep.2004007

Document status and date:

Published: 01/01/2004

DOI:

10.26481/umarep.2004007

Document Version:

Publisher's PDF, also known as Version of record

Please check the document version of this publication:

- A submitted manuscript is the version of the article upon submission and before peer-review. There can be important differences between the submitted version and the official published version of record. People interested in the research are advised to contact the author for the final version of the publication, or visit the $\mathrm{DOI}$ to the publisher's website.

- The final author version and the galley proof are versions of the publication after peer review.

- The final published version features the final layout of the paper including the volume, issue and page numbers.

Link to publication

\footnotetext{
General rights rights.

- You may freely distribute the URL identifying the publication in the public portal. please follow below link for the End User Agreement:

www.umlib.nl/taverne-license

Take down policy

If you believe that this document breaches copyright please contact us at:

repository@maastrichtuniversity.nl

providing details and we will investigate your claim.
}

Copyright and moral rights for the publications made accessible in the public portal are retained by the authors and/or other copyright owners and it is a condition of accessing publications that users recognise and abide by the legal requirements associated with these

- Users may download and print one copy of any publication from the public portal for the purpose of private study or research.

- You may not further distribute the material or use it for any profit-making activity or commercial gain

If the publication is distributed under the terms of Article $25 \mathrm{fa}$ of the Dutch Copyright Act, indicated by the "Taverne" license above, 


\section{Hoe oud-studenten van de Universiteit Maastricht hun curricula evalueren}

Tweede fase van het project "Curriculumevaluatie in het licht van de beroepspraktijk"

ROA-R-2004/7

G.W.M. Ramaekers

Researchcentrum voor Onderwijs en Arbeidsmarkt

Faculteit der Economische Wetenschappen en Bedrijfskunde

Universiteit Maastricht

Maastricht, september 2004 
ISBN 90-5321-395-3

Sec04.023 


\section{Inhoud}

Bladzijde

Voorwoord

Samenvatting iii

1 Inleiding 1

1.1 Aanleiding voor het project Curriculumevaluatie 1

1.2 Opzet van het project Curriculumevaluatie 2

1.2.1 Eerste fase van het project 2

1.2.2 Tweede fase van het project 3

1.3 Leeswijzer 4

2 Resultaten Faculteit der Geneeskunde 5

2.1 Competenties 5

2.2 Gewenste nadruk op didactische werkvormen 12

$\begin{array}{ll}2.3 \text { Oordeel over stage } & 14\end{array}$

2.4 Gewenste inrichting van het curriculum 14

2.5 Oordeel over voorbereiding op beroepspraktijk 20

$\begin{array}{ll}2.6 & \text { Conclusies en aanbevelingen } \\ \end{array}$

3 Resultaten Faculteit der Rechtsgeleerdheid 25

$\begin{array}{lll}3.1 & \text { Competenties } & 25\end{array}$

3.2 Gewenste nadruk op didactische werkvormen 32

$\begin{array}{lll}3.3 & \text { Oordeel over scriptie en stage } & 34\end{array}$

$\begin{array}{ll}3.4 & \text { Gewenste inrichting van het curriculum }\end{array}$

3.5 Oordeel over voorbereiding op beroepspraktijk 40

3.6 Conclusies en aanbevelingen 42

4 Resultaten Faculteit der Economische Wetenschappen en Bedrijfskunde $\quad 45$

4.1 Competenties $\quad 45$

4.2 Gewenste nadruk op didactische werkvormen 52

4.3 Oordeel over scriptie en stage $\quad 54$

4.4 Gewenste inrichting van het curriculum 55

4.5 Oordeel over voorbereiding op beroepspraktijk 61

4.6 Conclusies en aanbevelingen 63

5 Evaluatie van het project Curriculumevaluatie $\quad 67$

$\begin{array}{ll}\text { Literatuur } & 71\end{array}$

$\begin{array}{ll}\text { Bijlage } 1 & 73\end{array}$

$\begin{array}{lr}\text { Bijlage } 2 & 87\end{array}$ 



\section{Voorwoord}

Sinds 1990 verricht het Researchcentrum voor Onderwijs en Arbeidsmarkt (ROA) jaarlijks onderzoek naar de arbeidsmarktpositie en loopbanen van afgestudeerden van de Universiteit Maastricht (UM). Dit gebeurt met behulp van de zogeheten Arbeidsmarktscanner UM. Met behulp van deze metingen wordt niet alleen informatie over de actuele arbeidsmarktpositie van oud-studenten verzameld, maar wordt ook nagegaan hoe de afgestudeerden het gevolgde curriculum beoordelen in het licht van de eisen die de beroepspraktijk stelt. Dit laatste gebeurt echter in vrij algemene termen en biedt onvoldoende inzicht in de evaluatie van specifieke curriculumonderdelen. Er bestond dan ook de wens om een aanvullend instrument te ontwikkelen waarmee vanuit de vereisten van de beroepspraktijk meer specifieke informatie over de curricula kan worden verkregen. Dit aanvullende instrument is ontwikkeld in het project 'Curriculumevaluatie in het licht van de beroepspraktijk', dat in opdracht van het College van Bestuur van de UM is uitgevoerd.

Het project is in twee fasen uitgevoerd. In de eerste fase is het instrument ontwikkeld, en zijn met behulp van het ontwikkelde instrument in een pilot de curricula van de Faculteit der Gezondheidswetenschappen en Faculteit der Cultuurwetenschappen geëvalueerd. Hierover is in een eerder rapport verslag gedaan (JacobTacken \& Vaatstra, 2001). In de tweede fase van het project zijn de curricula van de andere faculteiten van de UM geëvalueerd. De resultaten die met behulp van het instrument over de curricula van deze andere faculteiten zijn verkregen, komen in dit rapport aan de orde.

Het project 'Curriculumevaluatie in het licht van de beroepspraktijk' is uitgevoerd door het ROA, in samenwerking met het Bureau Inschrijvingen van het Studentenservicecentrum van de UM en DESAN Research Solutions. Het ROA is verantwoordelijk voor de methodologische en inhoudelijke aspecten van het project. Het Bureau Inschrijvingen heeft gezorgd voor het bijhouden van het adressenbestand van de alumni, het verzenden van de vragenlijsten, en de non-responsactiviteiten. DESAN Research Solutions is verantwoordelijk voor de invoer van de onderzoeksgegevens en het verzorgen van het databestand. Binnen het ROA is het onderzoek uitgevoerd door dr. Rina Vaatstra (projectleider) en drs. Karin Jacob-Tacken. Deze rapportage over de resultaten van de tweede fase van het onderzoeksproject is opgesteld door drs. Ger Ramaekers. 



\section{Samenvatting}

In de eerste fase van het project Curriculumevaluatie in het licht van de beroepspraktijk zijn de opleidingen van de Faculteit der Gezondheidswetenschappen (FdGW) en Faculteit der Cultuurwetenschappen (FdCW) geëvalueerd. Dit rapport doet verslag van de resultaten en ervaringen die zijn opgedaan in de tweede fase van het project. Hierin zijn de opleidingen van de Faculteit der Geneeskunde (FdG), Faculteit der Rechtsgeleerdheid (FdR) en Faculteit der Economische Wetenschappen en Bedrijfskunde (FdEWB) geëvalueerd.

In dit rapport wordt achtereenvolgens beschreven hoe oud-studenten van de FdG, FdR en FdEWB van de Universiteit Maastricht, zo'n zes jaar na afstuderen, hun curriculum in het licht van hun huidige beroepspraktijk evalueren. In een separaat rapport is beschreven hoe hun loopbaan zich gedurende de eerste zes jaar na afstuderen heeft ontwikkeld (de Vries \& van Eijs, 2004).

\section{Oud-studenten van de FdG}

Aan het onderzoek hebben 47 oud-studenten Geneeskunde deelgenomen, wat neerkomt op een respons van $31 \%$. De resultaten hebben dus betrekking op een beperkt aantal oud-studenten, en dienen dan ook met de nodige voorzichtigheid te worden geïnterpreteerd. De meerderheid van deze oud-studenten vindt dat de opleiding hen voldoende heeft toegerust om adequaat te kunnen starten in de beroepspraktijk. Dit laat onverlet dat vier van de tien oud-studenten Geneeskunde aangeven dat zij bij de overgang naar de beroepspraktijk tekorten hebben ervaren in theoretische kennis. Daar staat tegenover dat de meerderheid van de respondenten Geneeskunde bij de overgang naar de beroepspraktijk geen tekorten heeft ervaren in praktische vaardigheden, noch in ervaring met praktijkproblemen en praktijksituaties. Het is dan ook niet verwonderlijk dat 'slechts' een op de drie oud-studenten vindt dat nascholing nodig is vanwege tekortkomingen in de opleiding.

Vrijwel alle onderzochte oud-studenten Geneeskunde zijn van mening dat de opleiding een goede basis heeft gelegd voor de verdere ontwikkeling van competenties. De overgrote meerderheid van de respondenten is van mening dat nascholing nodig is vanwege nieuwe ontwikkelingen die niet te voorzien zijn tijdens de opleiding, of om kennis en vaardigheden op te doen die beter te leren zijn in combinatie met werk.

Echter, wanneer de geënquêteerde oud-studenten Geneeskunde het curriculum opnieuw zouden mogen inrichten, dan zouden zij streven naar een verbreding van de opleiding en naar een meer beroepsgericht curriculum. Verder zouden zij een zwaarder accent leggen op het geven van presentaties, en in de opleiding meer aandacht besteden aan het vermogen om onder druk goed te functioneren, leiding te geven en informatie- \& communicatietechnologie te gebruiken. 


\section{Oud-studenten van de FdR}

Aan het onderzoek hebben 58 oud-studenten Rechtsgeleerdheid deelgenomen, wat neerkomt op een respons van $22 \%$. De analyse is echter beperkt tot 35 oudstudenten Rechtsgeleerdheid, namelijk degenen die werkzaam zijn in functies waarvoor de opleiding beoogde op te leiden. De resultaten hebben dus betrekking op een beperkt aantal studenten, en dienen dan ook met de nodige voorzichtigheid te worden geïnterpreteerd.

Hoewel het competentieniveau van oud-studenten Rechtsgeleerdheid toereikend is voor het niveau dat vereist is in hun functie, vindt bijna de helft van de geënquêteerde oud-studenten dat de opleiding hen onvoldoende heeft toegerust om adequaat te kunnen starten in de beroepspraktijk. Het gaat hierbij vooral om tekorten in praktische vaardigheden en omgang met praktijkproblemen/-situaties, en niet om tekorten in theoretische kennis. Tekorten in startbekwaamheid hoeven overigens niet problematisch te zijn voor hun verdere beroepsmatige ontwikkeling. Immers, vrijwel alle respondenten vinden dat de opleiding Rechtsgeleerdheid een goede basis heeft gelegd om kennis en vaardigheden verder te kunnen ontwikkelen. De meeste respondenten vinden dan ook dat nascholing niet nodig is vanwege tekortkomingen in de opleiding, maar vanwege nieuwe ontwikkelingen die niet te voorzien zijn tijdens de opleiding, of om kennis en vaardigheden op te doen die beter te leren zijn in combinatie met werk.

Wanneer de geënquêteerde oud-studenten Rechtsgeleerdheid het curriculum opnieuw zouden mogen inrichten, dan zouden zij streven naar een minder theoretisch gerichte opleiding en een zwaarder accent leggen op het opdoen van praktijkervaring en beroepsspecifieke vaardigheden. Zij zouden meer nadruk leggen op practica en vaardigheidstrainingen, en meer stagemogelijkheden bieden in de opleiding. Ook zouden zij meer aandacht besteden aan het vermogen om presentaties te geven.

\section{Oud-studenten van de FdEWB}

Aan het onderzoek hebben 63 oud-studenten Economie deelgenomen, wat neerkomt op een respons van $21 \%$. De analyse is echter beperkt tot 49 oud-studenten Economie, namelijk degenen die werkzaam zijn in functies waarvoor de opleiding beoogde op te leiden. De resultaten hebben dus betrekking op een beperkt aantal studenten, en dienen dan ook met de nodige voorzichtigheid te worden geïnterpreteerd.

Vier van de tien onderzochte oud-studenten Economie vinden dat de opleiding hen onvoldoende heeft toegerust om adequaat te kunnen starten in de beroepspraktijk. Het gaat hierbij vooral om tekorten in praktische vaardigheden en omgang met praktijkproblemen/-situaties, en niet om tekorten in theoretische kennis. Tekorten in startbekwaamheid hoeven overigens niet problematisch te zijn voor de verdere beroepsmatige ontwikkeling. Immers, vrijwel alle geënquêteerde oud-studenten Economie vinden dat de opleiding een goede basis heeft gelegd om kennis en 
vaardigheden verder te kunnen ontwikkelen. De meeste respondenten vinden dan ook dat nascholing niet nodig is vanwege tekortkomingen van de opleiding, maar vanwege nieuwe ontwikkelingen die niet te voorzien zijn tijdens de opleiding of om kennis en vaardigheden op te doen die beter te leren zijn in combinatie met werk.

Wanneer de geënquêteerde oud-studenten Economie het curriculum opnieuw zouden mogen inrichten, dan zouden zij streven naar een bredere opleiding en naar een meer op praktijkervaring en vaardigheden gerichte opleiding dan naar een theoretisch gerichte opleiding. De meeste oud-studenten Economie vinden dat er meer mogelijkheden zouden moeten zijn om stage te kunnen lopen, en dat een zwaarder accent op vaardigheidstrainingen gelegd zou moeten worden. Tot slot zouden zij in de opleiding meer aandacht besteden aan het vermogen om vakkennis in de praktijk toe te passen, conform budget en planning te werken, besluiten te nemen, in conflictsituaties adequaat te reageren, en leiding te geven. Wellicht omdat deze competenties te weinig aan bod zijn gekomen tijdens de opleiding, hebben de meeste oud-studenten deze competenties voornamelijk buiten of na de opleiding opgedaan of moeten opdoen. Het lijkt er overigens op dat de onderzochte oud-studenten Economie hier in zijn geslaagd, want hun niveau van deze competenties is uiteindelijk toereikend voor het niveau dat vereist is in hun functie.

\section{Algemene conclusies}

Van alle faculteiten bleek alleen de FdEWB behoefte te hebben om inzicht te krijgen in de wensen van werkgevers ten aanzien van de oud-studenten. Daarom is alleen voor de FdEWB de meting onder oud-studenten in het kader van het project Curriculumevaluatie uitgebreid met een meting onder hun werkgevers.

Uit evaluatiegesprekken naar aanleiding van de eerste fase van het project Curriculumevaluatie is gebleken dat de informatie van oud-studenten over de gewenste inrichting van het curriculum die met behulp van het onderzoeksinstrument wordt verkregen, bruikbare informatie heeft opgeleverd voor de opleiders van de FdGW en FdCW. Mede naar aanleiding van deze positieve ervaringen is de standaardmeting die circa anderhalf jaar na afstuderen plaatsvindt met ingang van 2003 verbeterd door twee curriculumvragen toe te voegen.

De tweede fase van het project heeft echter ook aangetoond dat de gehanteerde onderzoeksopzet qua respons niet goed werkt. Het aanhaken van het project Curriculumevaluatie aan de reguliere enquête onder oud-studenten lijkt een sterk responsverlagend effect te hebben gehad. De reguliere vragenlijst is in 2003 door het toevoegen van een omvangrijk blok vragen in het kader van het project Curriculumevaluatie ${ }^{1}$ beduidend langer geworden, met als gevolg dat veel oudstudenten afhaakten.

Ook de respons in de werkgeversenquête die voor de FdEWB is uitgevoerd, bleek teleurstellend laag te zijn. Een brede waaier van factoren blijkt hierbij een rol te

1. Vragenblok $F$ van de in bijlage 1 opgenomen vragenlijst. 
spelen. De belangrijkste reden voor de teleurstellend lage respons lijkt verband te houden met de gekozen onderzoeksopzet. Hierbij zijn de oud-studenten gevraagd om de werkgeversvragenlijst door te geven aan hun directe leidinggevende. Waarschijnlijk was de combinatie van een uitgebreide vragenlijst voor de oud-student zelf en het verzoek een werkgeversvragenlijst door te geven aan de direct leidinggevende net iets teveel gevraagd. Een aanwijzing hiervoor is dat ook de respons onder de oud-studenten zelf negatief lijkt te zijn beïnvloed.

\section{Aanbevelingen}

Het feit dat de betrokkenen van de faculteiten in de eerste fase van het project de resultaten van het curriculumonderzoek positief hebben beoordeeld, geeft de wenselijkheid aan om het ontwikkelde vragenblok over de evaluatie van het curriculum systematisch in te zetten om de faculteiten periodiek op de hoogte te houden over de opvattingen van alumni over het door hen gevolgde curriculum. Hiervoor is echter een hogere respons nodig.

De animo van oud-studenten om aan het onderzoek mee te werken, kan worden vergroot door bondiger vragenlijsten te gebruiken. Dit kan alleen door het vragenblok over curriculumevaluatie los te koppelen van de vragenlijst over de loopbaan, dus om de meting over curriculumevaluatie los te koppelen van de meting over de loopbaan. Het is overigens ook raadzaam om de omvang van de loopbaanvragenlijst zelf kritisch onder de loep te nemen.

Ook dient te worden nagedacht over een andere opzet van de dataverzameling, waarbij Internet een belangrijke rol speelt. Via Internet komen allerlei nieuwe manieren beschikbaar om het onderzoek aantrekkelijker te maken voor de oudstudenten. Beoogd wordt hen daarmee te prikkelen de vragenlijst in te vullen. Zo wordt het mogelijk feedback te geven, op maat gesneden informatie toe te sturen over bijvoorbeeld de arbeidsmarktpositie van de afgestudeerden van hun jaargang of studierichting en de oud-studenten op de hoogte te houden over de voortgang van het onderzoek. Een benadering van oud-studenten via Internet maakt het ook makkelijker om de meting over curriculumevaluatie los te koppelen van de meting over de loopbaan.

Bij de werkgeversenquête is gebleken dat een benadering van het werkveld via de oud-studenten tot een te lage en niet representatieve respons leidt. Een wellicht betere optie is om in de reguliere enquêtes onder oud-studenten te vragen naar de naam en het adres van de werkorganisatie en later, los van de enquêtes onder oudstudenten, de werkgevers rechtstreeks te benaderen. 


\section{$1 \quad$ Inleiding}

\subsection{Aanleiding voor het project Curriculumevaluatie}

In de maatschappij zien we dat het belang van kennis als productiefactor mede onder invloed van de informatie- en communicatietechnologie enorm is toegenomen (Nedermijer \& Pilot, 2000). Het werken met ideeën, begrippen, modellen en informatie lijkt steeds belangrijker te worden en de productie van nieuwe kennis vindt in een hoog tempo plaats (Weggeman, 1997). Mede door technologische ontwikkelingen, hogere kwaliteitseisen en steeds veeleisender klanten neemt de complexiteit van activiteiten toe. Deze ontwikkelingen kunnen een belangrijke invloed hebben op de inhoud van functies (Webbink \& Paape, 1997). Het routinewerk zal bijvoorbeeld afnemen en men dient zich steeds vaker te concentreren op nieuwe problemen en creatieve oplossingen (Van Delden, 1997). Aan professionals worden dan ook steeds hogere eisen gesteld.

Uit onderzoek is gebleken dat de arbeidsmarkt, gezien de continue veranderingen, een groeiende behoefte heeft aan breed inzetbare medewerkers. Vertegenwoordigers van bedrijven en instellingen geven in een onderzoek van Webbink \& Paape (1997) dan ook aan, dat zij de voorkeur geven aan breed opgeleide afgestudeerden. Daarnaast blijken zij vooral behoefte te hebben aan afgestudeerden die goed getraind zijn in communicatieve en sociale vaardigheden. Bovendien vinden afgevaardigden van bedrijven dat afgestudeerden moeten beschikken over het juiste leeren aanpassingsvermogen (Webbink \& Paape, 1997). Willen opleidingen goed op de arbeidsmarkt aansluiten, dan zou de basis van deze competenties al tijdens de opleiding moeten zijn gevormd. De inrichting van de opleiding zou afgestudeerden immers de juiste bagage mee moeten geven om zo goed mogelijk op de arbeidsmarkt te kunnen functioneren. Het project 'Curriculumevaluatie in het licht van de beroepspraktijk' is opgestart om de vereisten die gewenst zijn in de arbeidsmarkt terug te koppelen naar de betreffende curricula.

Met behulp van de 'Arbeidsmarktscanner UM' verricht het Researchcentrum voor Onderwijs en Arbeidsmarkt (ROA) sinds 1990 jaarlijks onderzoek naar de arbeidsmarktpositie en loopbanen van afgestudeerden van de Universiteit Maastricht (UM). In dit onderzoek worden afgestudeerden op drie momenten in hun loopbaan schriftelijk geënquêteerd: 1,5 jaar $(t+1), 5,5$ jaar $(t+5)$ en 10,5 jaar $(t+10)$ na afstuderen. In deze drie metingen wordt niet alleen informatie verzameld over de actuele arbeidsmarktpositie, maar wordt ook nagegaan hoe de afgestudeerden het gevolgde curriculum beoordelen. Dit laatste gebeurt echter in vrij algemene termen. Er bestond dan ook de wens om een aanvullend instrument te ontwikkelen waarmee vanuit de vereisten van de beroepspraktijk meer specifieke informatie over de curricula kan worden verkregen. Dit instrument, dat wordt gezien als een aanvulling en uitbreiding op de informatie die met de Arbeidsmarktscanner wordt verzameld, is ontwikkeld in het project 'Curriculumevaluatie in het licht van de beroepspraktijk'. 


\subsection{Opzet van het project Curriculumevaluatie}

\subsubsection{Eerste fase van het project}

Het project Curriculumevaluatie in het licht van de beroepspraktijk is in twee fasen uitgevoerd. In de eerste fase is het instrument ontwikkeld, en zijn met behulp van het ontwikkelde instrument in een pilot de curricula van de Faculteit der Gezondheidswetenschappen (FdGW) en Faculteit der Cultuurwetenschappen (FdCW) geëvalueerd. De pilot meting heeft plaatsgevonden in 2000 en had betrekking op gezondheidswetenschappers en cultuurwetenschappers die zijn afgestudeerd in 1995/1996.

Voorafgaand aan het ontwikkelen van een nieuw vragenblok over de evaluatie van het curriculum is zowel vanuit de FdGW als vanuit de FdCW een klankbordgroep opgericht. Daarnaast is contact gezocht met het Loopbaancentrum voor studenten van de UM. Met alle betrokken partijen zijn besprekingen gevoerd aan de hand van analyses van de data die met de Arbeidsmarktscanner UM zijn verkregen. Vervolgens is een conceptvragenlijst ontwikkeld. De conceptvragenlijst is daarna met beide klankbordgroepen en een medewerkster van het Loopbaancentrum voor studenten besproken en aangepast.

Voordat de schriftelijke enquête is verstuurd, is een aantal mondelinge interviews afgenomen onder afgestudeerden van de FdGW en FdCW. Het doel van deze interviews was tweeledig: ten eerste nagaan of de vragen in de vragenlijst eenduidig waren gesteld en ten tweede achterhalen of er nog onderwerpen ontbraken in de conceptvragenlijst. Aan de hand van de reacties en antwoorden van de geïnterviewde oud-studenten zijn aanpassingen verricht voor de curriculumvragenlijst, die in de eerste fase van het project Curriculumevaluatie is gebruikt (zie: Jacob-Tacken \& Vaatstra, 2001).

Aangezien de klankbordgroepen van de FdGW en FdCW weinig behoefte hadden om een overzicht te krijgen van de wensen van werkgevers over de afgestudeerden, zijn werkgevers in de eerste fase van het project niet meegenomen.

Het doel van het te ontwikkelen instrument was specifieke informatie te krijgen vanuit de beroepspraktijk over de gewenste inrichting van het curriculum. Uit evaluatiegesprekken met de leden van de klankbordgroepen van de FdGW en FdCW bleek dat vertegenwoordigers van beide faculteiten positief waren over de bruikbaarheid van de verkregen informatie. De aanbevelingen, die op basis van de onderzoeksresultaten zijn geformuleerd (zie: Jacob-Tacken \& Vaatstra, 2001), bleken zowel voor gezondheidswetenschappen als voor cultuurwetenschappen herkenbaar, interessant en bruikbaar te zijn, en zijn gedeeltelijk ter verbetering van het curriculum overgenomen. Het feit dat betrokkenen van de faculteiten de resultaten van het curriculumonderzoek positief beoordeeld hebben, geeft aan dat het ontwikkelde vragenblok over de evaluatie van het curriculum systematisch ingezet zou kunnen worden om de faculteiten periodiek op de hoogte te houden over de opvattingen van alumni over het door hen gevolgde curriculum. 
Voor een uitgebreide beschrijving van de ontwikkeling van het vragenblok over curriculumevaluatie en van de ervaringen die hiermee zijn opgedaan bij het evalueren van de curricula van de FdGW en FdCW wordt verwezen naar Jacob-Tacken \& Vaatstra (2001).

\subsubsection{Tweede fase van het project}

Op basis van de positieve ervaringen van de eerste fase van het project, heeft het College van Bestuur van de UM besloten om in een tweede fase het onderzoeksinstrument uit te breiden naar de Faculteit der Geneeskunde (FdG), Faculteit der Rechtsgeleerdheid (FdR) en Faculteit der Economische Wetenschappen en Bedrijfskunde (FdEWB), en in overleg met deze faculteiten verder te verfijnen. Dit is gebeurd in overleg met prof. dr. A. Scherpbier, drs K. Prince en dr. D. Dolmans namens de FdG, met prof. dr. F. Dochy namens de FdR, en met dr. M. Heijltjes, prof. dr. W. Gijselaers en dr. T. van Veen namens de FdEWB. De verfijning van het instrument heeft onder meer bestaan uit het opnemen van opleidingspecifieke competenties (zie bijlage 1).

Vanuit de FdEWB bestond behoefte om ook de mening van werkgevers te betrekken in het onderzoek. Daartoe is een vragenlijst voor werkgevers ontwikkeld (zie: bijlage 2). Gekozen is om de werkgevers via de oud-studenten te benaderen. In het werkgeversonderzoek, dat voor de FdEWB is uitgevoerd, werd aan de werkgever middels een schriftelijke vragenlijst een aantal vragen voorgelegd. Met deze vragen werd beoogd inzicht te verkrijgen in:

1. het selectieproces van nieuwe werknemers en de rol die de opleiding en competenties daarin spelen;

2. het oordeel van werkgevers over de opleiding.

De oud-studenten van de FdEWB is gevraagd om de werkgeversvragenlijst aan hun directe leidinggevende door te geven. Hiermee werd beoogd een representatieve steekproef onder werkgevers te creëren. Bovendien zou deze opzet het mogelijk maken de informatie afkomstig van de oud-student en van zijn of haar werkgever aan elkaar te koppelen. Helaas heeft de pilot onder werkgevers niet het gewenste resultaat opgeleverd. De respons is met minder dan $5 \%(4,6 \%)$ bijzonder laag gebleken. Op de oorzaken van deze teleurstellende respons wordt in hoofdstuk 5 ingegaan.

Zoals eerder is vermeld, zijn in de tweede fase van het project de curricula van de FdG, FdR en FdEWB geëvalueerd. Dit is gebeurd door het vragenblok over curriculumevaluatie op te nemen in de reguliere $t+5$ meting, die eind 2003 is gehouden onder afstudeerjaargang 1996/1997. Er is dus voor gekozen om alumni te enquêteren die ongeveer zes jaar op de arbeidsmarkt hebben doorgebracht. Deze alumni hebben doorgaans al een aantal functies uitgeoefend en zijn in staat om vanuit verschillende arbeidsmarktposities aan te geven wat ze tijdens de opleiding hebben gemist. In dit rapport wordt beschreven hoe oud-studenten (afstudeercohort 1996/ 1997) van deze faculteiten hun curricula evalueren in het licht van bijna zes jaar arbeidsmarktervaring. Voor een analyse van de wijze waarop de loopbaan van 
afstudeercohort 1996/1997 zich heeft ontwikkeld, wordt verwezen naar De Vries \& Van Eijs (2004).

\subsection{Leeswijzer}

In hoofdstuk 2 t/m 4 wordt achtereenvolgens voor de FdG, FdR en FdEW volgens steeds hetzelfde stramien verslag gedaan van de wijze waarop de oud-studenten een aantal aspecten van hun opleiding evalueren. Deze aspecten betreffen achtereenvolgens:

- de competenties waarover oud-studenten (dienen te) beschikken en de aandacht die de opleiding hieraan zou moeten besteden (paragraaf 1);

- de nadruk die oud-studenten zouden leggen op verschillende didactische werkvormen (paragraaf 2);

- $\quad$ het nut dat oud-studenten toekennen aan de studieonderdelen scriptie en stage (paragraaf 3);

- de accenten die oud-studenten zouden leggen in de gerichtheid van het curriculum op een aantal aspecten (paragraaf 4);

- hun oordeel over de mate waarin de opleiding hen heeft voorbereid op de beroepspraktijk en het belang van nascholing hierbij (paragraaf 5).

Tot slot worden steeds in paragraaf 6 de belangrijkste bevindingen samengevat in de vorm van een aantal conclusies en aanbevelingen voor de desbetreffende faculteit. Omdat de facultaire hoofdstukken met de onderzoeksresultaten steeds volgens hetzelfde stramien zijn opgezet, zijn deze hoofdstukken separaat leesbaar.

Het rapport wordt in hoofdstuk 5 afgerond met een schets van de bevindingen die zijn opgedaan met de onderzoeksmethodiek die is gebruikt in het project Curriculumevaluatie. Op basis van de bevindingen wordt een aantal aanbevelingen geformuleerd voor de opzet van een vervolg van het project. 


\section{Resultaten Faculteit der Geneeskunde}

In dit hoofdstuk worden de resultaten besproken van het eind 2003 uitgevoerde curriculumonderzoek onder oud-studenten van afstudeerjaargang 1996/1997. De resultaten hebben dus betrekking op oud-studenten die op het moment van de enquête zo'n zes jaar op de arbeidsmarkt vertoeven. Op de enquête hebben 47 oudstudenten Geneeskunde gerespondeerd (respons 31\%).

In de enquête is aan de oud-studenten gevraagd om een aantal aspecten van hun opleiding te evalueren. Deze aspecten betreffen achtereenvolgens de competenties waarover oud-studenten (dienen te) beschikken en de aandacht die de opleiding hieraan zou moeten besteden (paragraaf 2.1), de nadruk die oud-studenten zouden leggen op verschillende didactische werkvormen (paragraaf 2.2), het nut dat oudstudenten toekennen aan de stage (paragraaf 2.3), de accenten die oud-studenten zouden leggen in de gerichtheid van het curriculum op een aantal aspecten (paragraaf 2.4), hun oordeel over de mate waarin de opleiding hen heeft voorbereid op de beroepspraktijk en het belang van nascholing hierbij (paragraaf 2.5). Tot slot worden in paragraaf 2.6 de belangrijkste bevindingen samengevat in de vorm van een aantal conclusies en aanbevelingen.

\subsection{Competenties}

\section{Waarom meting van competenties?}

Er zijn verschillende redenen om onderzoek naar competenties van hoger opgeleiden verder te ontwikkelen. In de eerste plaats kunnen gegevens over competenties worden gebruikt voor het bewaken en verbeteren van de kwaliteit van opleidingen in termen van de mate waarin zij afgestudeerden hebben voorbereid op de beroepspraktijk. Dezelfde gegevens kunnen ook worden gebruikt om effecten van veranderingen in het hoger onderwijs te evalueren, zoals de invoering van het bamastelsel. Tot slot kunnen gegevens over competenties helpen om meer inzicht te krijgen in hoe de arbeidsmarkt werkt. Hieronder wordt nader ingegaan op deze drie redenen om competenties te meten.

Tegen de achtergrond van de invoering van een systeem van accreditering in het kader van de kwaliteitszorg van het hoger onderwijs, is de laatste jaren een verschuiving waar te nemen in de informatiebehoefte van degenen die zich bezig houden met diverse aspecten van de kwaliteit van het hoger onderwijs. Werd in het verleden meer naar de inputfactoren en het onderwijsproces zelf gekeken, thans wordt meer het accent gelegd op de eindtermen en de gewenste output van opleidingen. Hierbinnen is ook een verschuiving opgetreden, van de onderwijsprestaties zelf (geïndiceerd door bijvoorbeeld eindexamenresultaten) naar de competenties waarover afgestudeerden (dienen te) beschikken. De redenering hierbij is simpel: "the proof of the pudding is in the eating", en opleidingen kunnen het beste hun kwaliteit aantonen middels de geschiktheid van de afgestudeerden om in de praktijk te functioneren. 
Een tweede reden om zicht te krijgen op de competenties van afgestudeerden betreft de invoering van de bachelor-master structuur. Deze raakt de verhouding in oriëntatie tussen het hoger beroepsonderwijs en het wetenschappelijk onderwijs, en de differentiatie in twee uitstroomniveaus. Het meten van competenties is in dit kader van belang voor het ontwikkelen van een transparante kwalificatiestructuur van het hoger onderwijs en voor de organiseerbaarheid van het hoger onderwijs.

Naast bovengenoemde institutionele redenen is meting van competenties uit wetenschappelijk oogpunt relevant, omdat hiermee een beter inzicht in de werking van de arbeidsmarkt kan worden verkregen. Over de betekenis van onderwijs voor het latere beroepsmatig functioneren bestaan verschillende theorieën. Deze verschillen enerzijds met betrekking tot de vraag in hoeverre competenties in het onderwijs worden opgedaan (en zo ja welke competenties), en anderzijds met betrekking tot de vraag welke rol competenties spelen bij selectie, allocatie en beloning van werkenden. Een tweede punt van discussie betreft de vraag wat voor soort competenties op de arbeidsmarkt worden gevraagd. Wat is het relatieve belang van specifieke competenties ten opzichte van de meer generieke competenties? Worden in de transitiefase van school naar werk andere competenties gevraagd dan in latere fasen van de loopbaan? Welke competenties hebben oud-studenten nodig om snel productief inzetbaar te zijn (startbekwaam) en welke competenties verzekeren hun employability op langere termijn? Wat betekent dit voor het curriculum? Deze vragen zijn van wezenlijk belang, niet alleen vanuit theoretische optiek maar ook om te komen tot een meer effectieve en efficiënte inrichting van het onderwijs.

Tegen de bovengeschetste achtergrond is aan alle oud-studenten een lijst voorgelegd van 31 generieke competenties die in het werk van belang kunnen zijn. Deze lijst van generieke competenties is voor oud-studenten Geneeskunde uitgebreid met 9 opleidingspecifieke competenties.

Aan de oud-studenten is gevraagd om voor iedere competentie een inschatting te geven van achtereenvolgens:

- $\quad$ het niveau dat vereist is in hun huidige functie;

- $\quad$ hun eigen niveau;

- $\quad$ waar zij de competentie vooral hebben geleerd.

Zowel het vereiste als het eigen niveau konden zij aangeven op een vijfpuntschaal (van 'relatief laag' $t / m$ 'relatief hoog'). De belangrijkste leerbron van de competentie konden zij aangeven op een vijfpuntschaal (van 'buiten de WO-opleiding' $t / m$ 'in de WO-opleiding').

\section{Vereist niveau van competenties}

Kolom 2 van tabel 2.1 toont voor iedere competentie welk percentage van de betaald werkende oud-studenten het in de functie vereiste niveau als hoog inschat (antwoordcategorie 4 of 5). Opleidingspecifieke competenties die de meeste oudstudenten Geneeskunde op een hoog niveau moeten beheersen zijn: kennis van het eigen vakgebied, het vermogen om medische problemen op te lossen, diagnostische en therapeutische handelingen te verrichten en op de hoogte te blijven van nieuwe 
medische ontwikkelingen. Van de opleidingspecifieke competenties hoeven beduidend minder oud-studenten - alhoewel nog steeds meer dan de helft - op een hoog niveau het vermogen te hebben om actief sturing te geven aan de professionele ontwikkeling en bij medische beslissingen ethische en maatschappelijke aspecten te betrekken.

Tabel 2.1

Vereist en eigen competentieniveau, FdG (\% hoog niveau*)

\begin{tabular}{|c|c|c|}
\hline & $\begin{array}{l}\text { Vereist } \\
\text { niveau }\end{array}$ & $\begin{array}{r}\text { Eigen } \\
\text { niveau }\end{array}$ \\
\hline \multicolumn{3}{|l|}{ Kennis van: } \\
\hline het eigen vakgebied & 92 & 80 \\
\hline - $\quad$ andere vakgebieden & 58 & 43 \\
\hline \multicolumn{3}{|l|}{ Vermogen om: } \\
\hline - vakkennis in de praktijk toe te passen & 97 & 92 \\
\hline - informatie te vergaren & 86 & 80 \\
\hline problemen te analyseren en op te lossen & 100 & 94 \\
\hline - verbanden te leggen tussen verschillende zaken & 97 & 91 \\
\hline - hoofdzaken van bijzaken te onderscheiden & 97 & 92 \\
\hline logisch te redeneren & 89 & 94 \\
\hline conform budget en planning te werken & 28 & 19 \\
\hline - $\quad$ onder druk goed te functioneren & 97 & 87 \\
\hline besluiten te nemen & 92 & 90 \\
\hline nieuwe ideeën en oplossingen te bedenken & 65 & 58 \\
\hline - continue te leren & 86 & 70 \\
\hline aan anderen duidelijk te maken wat $u$ bedoelt & 94 & 86 \\
\hline met anderen samen te werken & 97 & 95 \\
\hline - leiding te geven & 56 & 61 \\
\hline zelfstandig te werken & 94 & 89 \\
\hline in conflictsituaties adequaat te reageren & 83 & 78 \\
\hline presentaties te geven & 68 & 55 \\
\hline - $\quad$ gesprekken te voeren & 92 & 92 \\
\hline rapporten en brieven te schrijven & 73 & 71 \\
\hline _ $\quad$ in buitenlandse talen te communiceren & 17 & 47 \\
\hline - ICT te gebruiken & 54 & 43 \\
\hline \multicolumn{3}{|l|}{ Bereidheid om: } \\
\hline - werkgerelateerde risico's te nemen & 69 & 60 \\
\hline - ideeën van uzelf en anderen ter discussie te stellen & 70 & 62 \\
\hline - op te komen voor uw eigen standpunt & 92 & 62 \\
\hline - $\quad$ begrip te tonen voor andere standpunten & 78 & 81 \\
\hline - verantwoordelijkheid te nemen & 97 & 94 \\
\hline - $\quad$ kritisch na te denken over uw eigen handelen & 89 & 83 \\
\hline uw gedrag aan te passen aan de situatie & 89 & 83 \\
\hline - feedback te ontvangen en te geven & 83 & 75 \\
\hline \multicolumn{3}{|l|}{ Vermogen om (opleidingspecifiek): } \\
\hline - diagnostische en therapeutische handelingen te verrichten & 89 & 84 \\
\hline - te communiceren met patiënten & 81 & 92 \\
\hline - op de hoogte te blijven van nieuwe medische ontwikkelingen & 89 & 71 \\
\hline nieuwe medische inzichten te gebruiken & 87 & 70 \\
\hline - medische problemen op te lossen & 95 & 84 \\
\hline - medisch handelen wetenschappelijk te onderbouwen & 76 & 61 \\
\hline - $\quad$ actief sturing te geven aan de professionele ontwikkeling & 54 & 40 \\
\hline - bij medische beslissingen ethische en mij. Aspecten te betrekken & 65 & 63 \\
\hline - patiënt in relatie tot zijn omgeving te benaderen en te behandelen & 78 & 84 \\
\hline
\end{tabular}

* Percentage oud-studenten dat 4 of 5 scoort op een schaal van 1 (relatief laag) t/m 5 (relatief hoog). 
Kijken we naar de generieke competenties, dan moeten tenminste negen van de tien oud-studenten geneeskunde op een hoog niveau beschikken over:

- $\quad$ het vermogen om vakkennis in de praktijk toe te passen;

- analytische competenties (vermogen om problemen te analyseren en op te lossen, verbanden te leggen tussen verschillende zaken, en hoofdzaken van bijzaken te onderscheiden);

- communicatieve competenties (vermogen om aan anderen duidelijk te maken wat men bedoelt en gesprekken te voeren);

- $\quad$ onder druk goed te functioneren en besluiten te nemen;

- $\quad$ met anderen samen te werken en zelfstandig te werken;

- de bereidheid om verantwoordelijkheid te nemen en op te komen voor het eigen standpunt.

\section{Eigen niveau van de competenties}

Kolom 3 van tabel 2.1 toont voor iedere competentie welk percentage van de oudstudenten het eigen niveau als hoog inschat (antwoordcategorie 4 of 5). Van de opleidingspecifieke competenties schatten oud-studenten Geneeskunde hun vermogen om diagnostische en therapeutische handelingen te verrichten, medische problemen op te lossen, de patiënt in relatie tot zijn omgeving te benaderen en te behandelen, en vooral te communiceren met patiënten het vaakst als hoog in. Meer dan $80 \%$ van de geënquêteerde oud-studenten vindt dat zij deze competenties op hoog niveau beheersen. Het minst vaak schatten zij hun vermogen om actief sturing te geven aan de professionele ontwikkeling als hoog in.

Met betrekking tot de generieke competenties, schat minder dan de helft van de oudstudenten hun kennis van andere vakgebieden en hun vermogen om conform budget en planning te werken, in buitenlandse talen te communiceren en informatie- \& communicatietechnologie te gebruiken als hoog in.

\section{Discrepanties tussen vereist niveau en eigen niveau van competenties}

De discrepantie tussen het vereiste niveau en het aanwezige niveau van competenties geeft per competentieaspect een indicatie voor eventuele tekorten of overschotten, en kan daarmee licht werpen op de vraag in hoeverre opleidingen van de UM de kwaliteit leveren die op de arbeidsmarkt van hen wordt verlangd.

Als eerste valt op dat oud-studenten bij de meeste competenties hun eigen niveau (iets) lager inschatten dan het niveau dat vereist is in hun functie. Alleen bij het vermogen om te communiceren met patiënten en in buitenlandse talen te communiceren, schatten zij hun eigen niveau duidelijk hoger in dan het niveau dat vereist is in hun functie (verschil tenminste 10\%-punt).

Vergelijking van het vereiste competentieniveau met het 'eigen' competentieniveau (tabel 2.1) toont dat bij twee generieke en drie opleidingspecifieke competenties het procentuele aandeel van oud-studenten die hun eigen niveau als hoog inschatten tenminste $15 \%$-punt lager ligt dan het procentuele aandeel van oud-studenten die het 
vereiste niveau als hoog inschatten. Bij de generieke competenties gaat het om kennis van andere vakgebieden en de bereidheid om op te komen voor het eigen standpunt, en bij de opleidingspecifieke competenties om het vermogen om op de hoogte te blijven van nieuwe medische ontwikkelingen, nieuwe medische inzichten te gebruiken en medisch handelen wetenschappelijk te onderbouwen.

In tabel 2.3 wordt nagegaan in hoeverre de aandacht die de opleiding aan competenties besteedt volgens de oud-studenten zou moeten worden bijgesteld. Echter, aangezien competenties slechts ten dele binnen het initieel onderwijs worden opgedaan, wordt eerst in tabel 2.2 nagegaan in welke mate oud-studenten de competenties vooral in de initiële WO-opleiding hebben opgedaan.

\section{Belangrijkste leerbron van competenties}

Competenties worden niet alleen tijdens het volgen van een initiële opleiding opgedaan maar ook na het afstuderen, bijvoorbeeld in postdoctorale beroepsopleidingen en cursussen of tijdens de uitoefening van een beroep. Aan de oudstudenten is gevraagd om voor iedere competentie aan te geven waar zij de betreffende competentie vooral hebben geleerd. Zij konden dit aangeven op een vijfpuntschaal (van 1 'buiten de WO-opleiding' t/m 5 'in de WO-opleiding'). Tabel 2.2 toont voor iedere competentie welk percentage van de oud-studenten aangeeft dat de betreffende competentie vooral in de WO-opleiding is opgedaan (antwoordcategorie 4 of 5 ).

De tabel laat zien dat competenties vaak ook buiten of na de opleiding worden verworven. De volgende opleidingspecifieke competenties zijn door meer dan de helft van de oud-studenten vooral buiten of na de initiële opleiding opgedaan: het vermogen om op de hoogte te blijven van nieuwe medische ontwikkelingen, nieuwe medische inzichten te gebruiken, medisch handelen wetenschappelijk te onderbouwen, actief sturing te geven aan de professionele ontwikkeling en bij medische beslissingen ethische en maatschappelijke aspecten te betrekken.

Generieke competenties die vooral buiten of na de opleiding worden opgedaan, zijn het vermogen om conform budget en planning te werken, onder druk goed te functioneren, besluiten te nemen, leiding te geven, in conflictsituaties adequaat te reageren, rapporten en brieven te schrijven, in buitenlandse talen te communiceren, informatie- \& communicatietechnologie te gebruiken en actief sturing te geven aan de professionele ontwikkeling, alsmede de bereidheid om werkgerelateerde risico's te nemen. Deze competenties zijn door meer dan driekwart van de oud-studenten vooral buiten of na de opleiding opgedaan.

\section{Mening over bestede aandacht aan competenties}

Hieronder wordt nagegaan of de generieke en opleidingspecifieke competenties volgens de oud-studenten wel voldoende aan bod zijn gekomen tijdens hun WOopleiding. Daartoe is aan de oud-studenten gevraagd om van de generieke en opleidingspecifieke competenties er maximaal 3 te noemen waarvan zij vonden dat 
deze in hun WO-opleiding te weinig aan bod zijn gekomen, en die dus volgens hen meer aandacht hadden moeten krijgen. Aangezien meer aandacht voor de ene competentie, bij een gelijkblijvende studieduur, minder aandacht voor een andere competentie betekent, is aan de oud-studenten ook gevraagd om maximaal 3 competenties te noemen die naar hun mening te veel aan bod zijn gekomen. Tabel 2.3 toont de scores van oud-studenten Geneeskunde op beide vragen.

Tabel 2.2

Belangrijkste leerbron van competenties, FdG (\% in de WO-opleiding*)

Kennis van:

- $\quad$ het eigen vakgebied $\quad 44$

$\begin{array}{ll}\text { andere vakgebieden } & 32\end{array}$

Vermogen om:

- $\quad$ vakkennis in de praktijk toe te passen $\quad 46$

informatie te vergaren $\quad 74$

problemen te analyseren en op te lossen $\quad 66$

verbanden te leggen tussen verschillende zaken $\quad 49$

hoofdzaken van bijzaken te onderscheiden $\quad 50$

logisch te redeneren $\quad 53$

conform budget en planning te werken 3

onder druk goed te functioneren $\quad 14$

besluiten te nemen $\quad 22$

nieuwe ideeën en oplossingen te bedenken $\quad 27$

continue te leren $\quad 63$

aan anderen duidelijk te maken wat $\mathrm{u}$ bedoelt

$\begin{array}{ll}\text { met anderen samen te werken } & 61\end{array}$

leiding te geven $\quad 17$

zelfstandig te werken

in conflictsituaties adequaat te reageren $\quad 22$

presentaties te geven $\quad 36$

gesprekken te voeren $\quad 69$

rapporten en brieven te schrijven $\quad 17$

in buitenlandse talen te communiceren

ICT te gebruiken $\quad 11$

\begin{tabular}{ll} 
Bereidheid om: & 6 \\
\hline & werkgerelateerde risico's te nemen
\end{tabular}

- $\quad$ ideeën van uzelf en anderen ter discussie te stellen $\quad 50$

op te komen voor uw eigen standpunt

$\begin{array}{ll}\text { begrip te tonen voor andere standpunten } & 57\end{array}$

verantwoordelijkheid te nemen $\quad 26$

kritisch na te denken over uw eigen handelen $\quad 31$

uw gedrag aan te passen aan de situatie $\quad 26$

feedback te ontvangen en te geven $\quad 59$

Vermogen om (opleidingspecifiek):

- diagnostische en therapeutische handelingen te verrichten 50

- te communiceren met patiënten 68

op de hoogte te blijven van nieuwe medische ontwikkelingen 42

$\begin{array}{ll}\text { nieuwe medische inzichten te gebruiken } & 37\end{array}$

medische problemen op te lossen

medisch handelen wetenschappelijk te onderbouwen $\quad 29$

actief sturing te geven aan de professionele ontwikkeling $\quad 11$

bij medische beslissingen ethische en mij. aspecten te betrekken 45

patiënt in relatie tot zijn omgeving te benaderen en te behandelen 50

* Percentage oud-studenten dat 4 of 5 scoort op een schaal van 1 (buiten de WO-opleiding) $\mathrm{t} / \mathrm{m} 5$ (in de WO-opleiding). 
Tabel 2.3

Oordeel over de mate waarin competenties aan bod komen tijdens de opleiding, FdG (\%)

\begin{tabular}{|c|c|c|c|}
\hline & $\begin{array}{l}\text { Te veel } \\
\text { aan bod }\end{array}$ & $\begin{array}{l}\text { Te weinig } \\
\text { aan bod }\end{array}$ & $\begin{array}{l}\text { Saldo (te veel } \\
\text { - te weinig) }\end{array}$ \\
\hline \multicolumn{4}{|l|}{ Kennis van: } \\
\hline - $\quad$ het eigen vakgebied & 0 & 4 & -4 \\
\hline - $\quad$ andere vakgebieden & 0 & 0 & 0 \\
\hline \multicolumn{4}{|l|}{ Vermogen om: } \\
\hline - vakkennis in de praktijk toe te passen & 0 & 9 & -9 \\
\hline - informatie te vergaren & 30 & 0 & 30 \\
\hline - $\quad$ problemen te analyseren en op te lossen & 10 & 0 & 10 \\
\hline $\begin{array}{l}\text { verbanden te leggen tussen verschillende } \\
\text { zaken }\end{array}$ & 0 & 0 & 0 \\
\hline - hoofdzaken van bijzaken te onderscheiden & 0 & 9 & -9 \\
\hline - logisch te redeneren & 0 & 0 & 0 \\
\hline conform budget en planning te werken & 0 & 30 & -30 \\
\hline onder druk goed te functioneren & 0 & 22 & -22 \\
\hline - besluiten te nemen & 0 & 4 & -4 \\
\hline nieuwe ideeën en oplossingen te bedenken & 0 & 0 & 0 \\
\hline continue te leren & 10 & 0 & 10 \\
\hline - $\quad$ aan anderen duidelijk te maken wat $\mathrm{u}$ bedoelt & 0 & 0 & 0 \\
\hline - met anderen samen te werken & 10 & 0 & 10 \\
\hline leiding te geven & 0 & 26 & -26 \\
\hline zelfstandig te werken & 0 & 0 & 0 \\
\hline - in conflictsituaties adequaat te reageren & 0 & 13 & -13 \\
\hline presentaties te geven & 10 & 13 & -3 \\
\hline gesprekken te voeren & 0 & 0 & 0 \\
\hline rapporten en brieven te schrijven & 0 & 13 & -13 \\
\hline in buitenlandse talen te communiceren & 0 & 4 & -4 \\
\hline ICT te gebruiken & 0 & 35 & -35 \\
\hline \multicolumn{4}{|l|}{ Bereidheid om: } \\
\hline 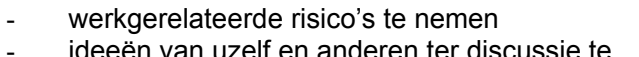 & 10 & 0 & 10 \\
\hline stellen & 10 & 0 & 10 \\
\hline op te komen voor uw eigen standpunt & 0 & 4 & -4 \\
\hline begrip te tonen voor andere standpunten & 0 & 0 & 0 \\
\hline verantwoordelijkheid te nemen & 0 & 9 & -9 \\
\hline - $\quad$ kritisch na te denken over uw eigen handelen & 0 & 0 & 0 \\
\hline - uw gedrag aan te passen aan de situatie & 0 & 0 & 0 \\
\hline - feedback te ontvangen en te geven & 10 & 4 & 6 \\
\hline \multicolumn{4}{|l|}{$\begin{array}{l}\text { Vermogen om (opleidingspecifiek): } \\
-\quad \text { diagnostische en therapeutische handelingen }\end{array}$} \\
\hline \multirow{9}{*}{$\begin{array}{l}\text { - } \begin{array}{l}\text { op de hoogte te blijven van nieuwe medischen } \\
\text { nieuwe medische inzichten te gebruiken } \\
\text { - }\end{array} \quad \begin{array}{l}\text { medische problemen op te lossen } \\
\text { onderbouwen handelen wetenschappelijk te }\end{array} \\
\text { actief sturing te geven aan de professionele } \\
\text { ontwikkeling } \\
\text { bij medische beslissingen ethische en mij. } \\
\text { aspecten te betrekken } \\
\text { patiënt in relatie tot zijn omgeving te } \\
\text { benaderen en te behandelen }\end{array}$} & 20 & 4 & 16 \\
\hline & 0 & 4 & -4 \\
\hline & 0 & 9 & -9 \\
\hline & 0 & 0 & 0 \\
\hline & 0 & 9 & -9 \\
\hline & 0 & 9 & 0 \\
\hline & & & \\
\hline & 10 & 9 & 1 \\
\hline & 20 & 0 & 20 \\
\hline
\end{tabular}


Als eerste valt op dat oud-studenten Geneeskunde slechts bij twee competenties duidelijk verdeeld zijn in hun mening over de mate waarin deze in hun opleiding aan bod zijn gekomen. Zo noemt bijvoorbeeld $10 \%$ het vermogen om bij medische beslissingen ethische en maatschappelijke aspecten te betrekken als één van de drie competenties die te veel aan bod zijn gekomen tijdens de opleiding Geneeskunde, terwijl een nagenoeg gelijk percentage (namelijk 9\%) deze competentie noemt als één van de drie die te weinig aan bod zijn gekomen. Dezelfde verdeeldheid zien we bij het vermogen om presentaties te geven.

Van de competenties die door meer dan de helft van de oud-studenten op een hoog niveau dienen te worden beheerst, zijn drie competenties door tenminste $20 \%$ van de oud-studenten genoemd als één van de drie competenties die te weinig aan bod zijn gekomen tijdens de opleiding Geneeskunde, terwijl niemand deze competenties heeft genoemd als één van de drie competenties die te veel aan bod zijn gekomen. Deze 'tekortschietende' competenties betreffen het vermogen om onder druk goed te functioneren, leiding te geven en informatie- \& communicatietechnologie te gebruiken. Wellicht omdat deze competenties te weinig aan bod komen tijdens de opleiding, hebben oud-studenten deze competenties vaak buiten of na de opleiding opgedaan of moeten opdoen (tabel 2.2). Het lijkt er overigens op dat oud-studenten hier slechts ten dele in zijn geslaagd, tenminste wat hun vermogen om informatie- \& communicatietechnologie te gebruiken betreft. Immers, minder dan de helft van de oud-studenten schat hun eigen niveau om informatie- \& communicatietechnologie te gebruiken als hoog in (tabel 2.1).

\subsection{Gewenste nadruk op didactische werkvormen}

De werkvormen waarmee studenten tijdens de opleiding in aanraking komen spelen een belangrijke rol bij de competentieverwerving. Naast activerende onderwijsmethoden, zoals PGO, kunnen activerende werkvormen worden aangeboden, waardoor studenten de mogelijkheid krijgen om kennis en vaardigheden toe te passen op complexe problemen en in 'gesimuleerde' praktijksituaties. In de opleiding kan de mogelijkheid worden geboden om kennis in de praktijk te brengen middels bijvoorbeeld vaardigheidstrainingen, practica, schrijfopdrachten en onderzoeksopdrachten. Bransford e.a. (1989) en Glaser (1991) stellen dat het opdoen van ervaring met praktijkproblemen - of simulaties daarvan - een goede voorbereiding vormt op een beroep. Enerzijds leren studenten beter om te gaan met multidisciplinaire situaties of problemen en zijn ze vaker gestimuleerd om multidisciplinaire kennis toe te passen. Anderzijds zijn afgestudeerden die vaker in de gelegenheid zijn geweest om hun kennis en vaardigheden te trainen in een realistische context, beter voorbereid op de beroepspraktijk dan afgestudeerden die minder vaak gebruik hebben gemaakt van actieve werkvormen.

\section{Gewenste nadruk op (activerende) werkvormen}

Aan de oud-studenten is gevraagd om bij een tiental (activerende) werkvormen aan te geven of hierop tijdens de opleiding minder, gelijk of meer nadruk gelegd zou moeten worden (tabel 2.4). Als eerste valt op dat bij alle in de vragenlijst opgenomen 
werkvormen vrijwel niemand opteert voor minder nadruk. Dit kan er op duiden dat oud-studenten door de bank genomen opteren voor meer 'contacturen' in de opleiding. Helaas was 'zelfstudie' als werkvorm niet opgenomen in de vragenlijst.

Tabel 2.4

Gewenste nadruk op werkvormen, FdG (\%)

\begin{tabular}{lccc}
\hline & Minder nadruk & Gelijke nadruk & Meer nadruk \\
\hline Onderwijsgroepen & 8 & 87 & 5 \\
Hoorcolleges & 0 & 40 & 61 \\
Groepsopdrachten & 9 & 54 & 37 \\
Vaardigheidstrainingen & 3 & 87 & 11 \\
Practica & 3 & 71 & 26 \\
Presentatie/voordracht & 3 & 18 & 79 \\
Computersimulaties/-games & 3 & 32 & 56 \\
Schrijfopdrachten & 3 & 42 & 58 \\
Onderzoeksopdrachten & 0 & 68 & 29 \\
Patiëntencontacten & 3 & & \\
\hline
\end{tabular}

Een overduidelijke meerderheid van de oud-studenten Geneeskunde is tevreden over de nadruk die in de opleiding wordt gelegd op onderwijsgroepen en vaardigheidstrainingen (elk $87 \%$ ), gevolgd door practica $(71 \%)$ en patiëntencontacten $(68 \%)$. Op presenteren $(79 \%)$ zou volgens een overduidelijke meerderheid méér nadruk gelegd moeten worden.

Enigszins verdeeld zijn de meningen over de gewenste nadruk op hoorcolleges, computersimulaties/-games, schrijfopdrachten en onderzoeksopdrachten. De meeste oud-studenten Geneeskunde vinden dat de opleiding meer nadruk zou moeten leggen op hoorcolleges, computersimulaties/-games, schrijfopdrachten en onderzoeksopdrachten. Echter, bij deze werkvormen is ook tenminste een op de drie oudstudenten tevreden over de nadruk die deze werkvormen hebben gekregen.

De oud-studenten zijn ook enigszins verdeeld over de gewenste nadruk op groepsopdrachten. Hoewel de meeste oud-studenten tevreden zijn over de nadruk die wordt gelegd op groepsopdrachten, vindt ruim een derde dat groepsopdrachten meer nadruk zouden moeten krijgen.

Algemeen oordeel over de wijze van voorbereiding op de beroepspraktijk

Aan de oud-studenten is ook gevraagd om op een vijfpuntschaal (van 'zeer oneens' $\mathrm{t} / \mathrm{m}$ 'zeer eens') aan te geven in welke mate zij het eens zijn met de uitspraak: 'Ik ben over het algemeen tevreden over de wijze waarop de opleiding mij heeft voorbereid op de beroepspraktijk". Gebleken is dat $88 \%$ van de geënquêteerde oud-studenten Geneeskunde deze uitspraak onderschrijft (antwoordcategorie 4 en 5). De overgrote meerderheid is dus tevreden over de wijze waarop de opleiding hen heeft voorbereid op de beroepspraktijk. 


\subsection{Oordeel over stage}

Aangezien de stage een belangrijk onderdeel ter voorbereiding op de arbeidsmarkt vormt, wordt dit studieonderdeel in dit hoofdstuk afzonderlijk besproken. In de enquête zijn drie stellingen over het studieonderdeel stage geponeerd. Aan de oud-studenten is gevraagd in hoeverre zij het met de stellingen eens zijn. De antwoorden zijn gemeten op een vijfpuntschaal, lopend van 1 'zeer oneens' tot en met 5 'zeer eens'. In deze paragraaf worden de procentuele aandelen van de oud-studenten gepresenteerd, die het met de desbetreffende stelling eens zijn (antwoordcategorie 4 of 5).

Tabel 2.5 laat zien dat alle oud-studenten Geneeskunde tijdens hun opleiding stage hebben gelopen (verplichte co-assistenschappen). Vrijwel iedereen vindt dat de stage een duidelijke meerwaarde geeft aan de opleiding. Wanneer we kijken naar de voorbereiding van de stage op de beroepspraktijk, dan zien we dat driekwart van de geënquêteerde oud-studenten Geneeskunde van mening is dat zij in de stage voldoende hebben geleerd voor de beroepspraktijk. Wat betreft de frequentie om stage te lopen, vindt een op de vijf oud-studenten dat stages vaker zouden mogen plaatsvinden.

Tabel 2.5

Oordeel over de stage, FdG: \% (zeer) met stelling eens*

Stage gelopen

(s) heb ik voldoende geleerd voor de praktiik

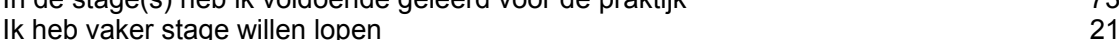

Het doen van een stage geeft een duidelijke meerwaarde aan de opleiding 95

* Percentage oud-studenten dat 4 of 5 scoort op een schaal van 1 (zeer oneens) t/m 5 (zeer eens).

Ten aanzien van stages zij opgemerkt, dat de relevantie hiervan niet alleen ligt in de voorbereiding op de beroepspraktijk maar ook in het opbouwen van een netwerk dat na de opleiding behulpzaam kan zijn bij het vinden van werk.

\subsection{Gewenste inrichting van het curriculum}

In deze paragraaf wordt beschreven op welke wijze oud-studenten Geneeskunde het curriculum na een aantal jaren arbeidsmarktervaring zouden willen aanpassen. Aan de oud-studenten is gevraagd stelling te nemen ten aanzien van een aantal curriculumkenmerken. De respondenten dienden daarbij een keuze te maken tussen twee tegengestelde opties. Deze opties stonden aan de linker- en rechterkant op een antwoordschaal van 1 tot en met 7 . Een voorbeeld: "Als ik de opleiding zou mogen aanpassen, dan gaat mijn voorkeur uit naar meer theorie (antwoordcategorie $1 \mathrm{t} / \mathrm{m} \mathrm{3}$ ) of meer vaardigheden (antwoordcategorie $5 \mathrm{t} / \mathrm{m} 7$ )". Wanneer men de opleiding niet zou willen aanpassen diende men antwoordcategorie 4 aan te geven. In deze paragraaf worden figuren gepresenteerd, die aangeven waar de voorkeur van de oudstudenten naar uitgaat. 


\section{Mate van specialisatie}

In de discussie over de inrichting van het onderwijs heeft het spanningsveld tussen een brede of een specialistische oriëntatie binnen opleidingen altijd een belangrijke rol gespeeld. Door het curriculum van een opleiding toe te spitsen op een specifiek beroep zijn de afgestudeerden optimaal voorbereid op dit beroep, en zal de productiviteit derhalve hoog zijn. Een nadeel van een dergelijke specialistische invulling van het onderwijs is echter dat de betreffende afgestudeerden sterk afhankelijk worden van de werkgelegenheidsontwikkeling van dit specifieke beroep. Om voldoende flexibiliteit op de arbeidsmarkt te kunnen waarborgen, is het vereist om de studenten breder op te leiden (Borghans \& De Grip, 1999, blz. 3). Daarbij is er in de praktijk, gegeven de beperkte studieduur, sprake van een spanningsveld tussen enerzijds het op een bepaald beroepsdomein gerichte specifieke vaktechnische karakter van een opleiding en anderzijds de competenties die een bredere inzetbaarheid op de arbeidsmarkt bewerkstelligen. In essentie gaat het hier om het spanningsveld tussen productiviteit en flexibiliteit. Tussen deze twee doelstellingen, productiviteit en flexibiliteit, dient een afweging te worden gemaakt (Borghans \& De Grip, 1999, blz. 26-27).

In de discussie over de inrichting van het onderwijs lijkt een golfbeweging te bestaan tussen enerzijds de roep om bredere kwalificaties en anderzijds de roep om beter toegeruste vakspecialisten. Met name de sterke technologische en organisatorische veranderingen van de laatste jaren hebben geleid tot een roep om werknemers met een hoge employability en sleutelkwalificaties, die niet zijn aangewezen op een specifiek beroep maar in een breder beroependomein inzetbaar zijn (Borghans \& De Grip, 1999, blz. 4).

Figuur 2.1

Breed versus specialistisch curriculum gewenst, FdG (\%)
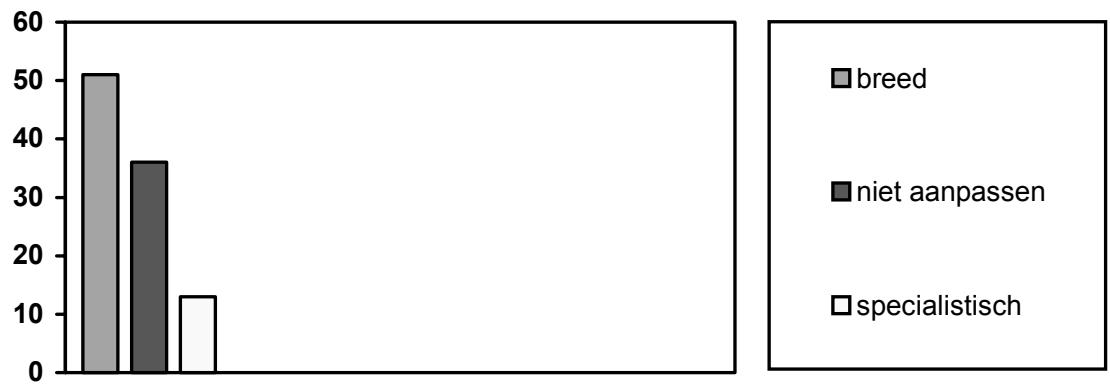

In welke mate oud-studenten Geneeskunde, achteraf bezien, een meer generiek dan wel meer specialistisch studieprogramma voorstaan, staat weergegeven in figuur 2.1. Uit de figuur komt duidelijk naar voren dat de grootste groep oud-studenten Geneeskunde een bredere opleiding voorstaat: de helft (51\%) van de respondenten geeft de voorkeur aan een breed programma, terwijl 'slechts' een op de acht oudstudenten (13\%) graag een meer specialistisch curriculum had gevolgd. Ruim een 
derde $(36 \%)$ zou het curriculum ten aanzien van de brede dan wel specialistische oriëntatie niet aanpassen.

\section{Beroepsgerichtheid}

Figuur 2.2 geeft weer hoeveel van de ondervraagde oud-studenten Geneeskunde een meer academisch gericht curriculum dan wel een meer beroepsgericht curriculum willen.

Figuur 2.2

Academisch versus beroepsgericht curriculum gewenst, FdG (\%)
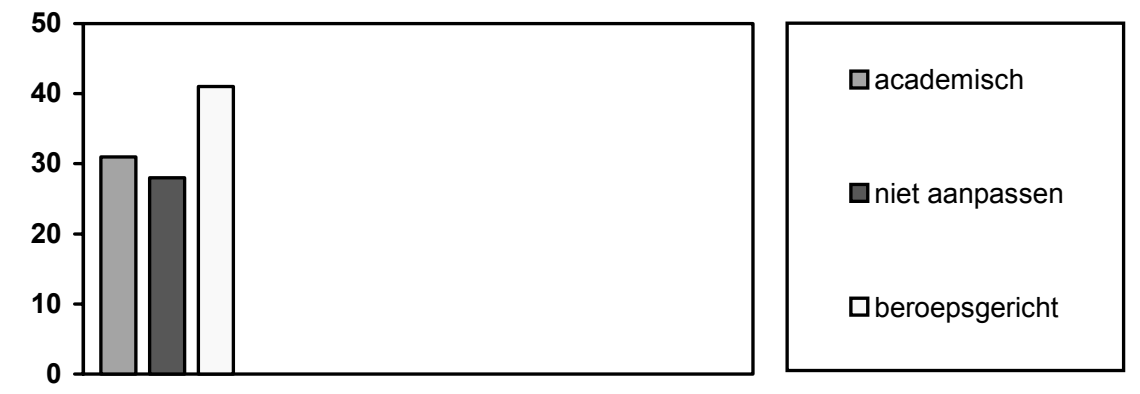

In figuur 2.2 komt naar voren dat de oud-studenten door de bank genomen een lichte voorkeur hebben voor een meer beroepsgericht curriculum: $41 \%$ staat een meer beroepsgericht curriculum voor, tegen $31 \%$ met een voorkeur voor een meer academisch gericht curriculum. Ruim een kwart (28\%) zou het curriculum wat dit betreft niet aanpassen.

Figuur 2.3

Meer praktijkervaring versus meer theoretische vakken, gewenst FdG (\%)

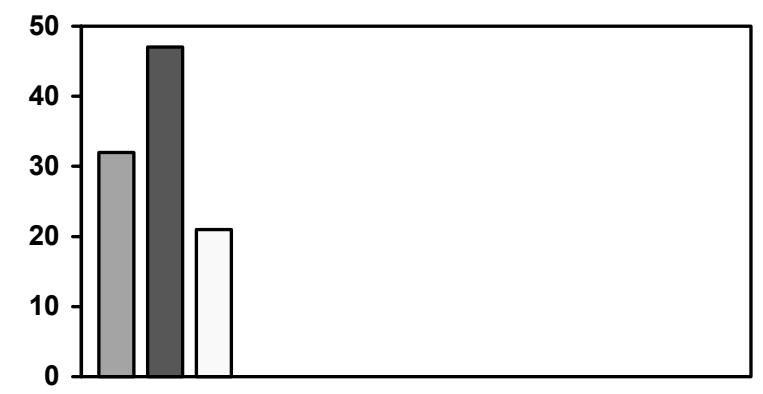

口meer praktijkervaring

$\square$ niet aanpassen

$\square$ meer theoretische vakken

\section{Praktijkgerichtheid}

Hoeveel oud-studenten meer praktijkervaring zouden inbouwen in de opleiding, dan wel meer theoretische vakken zouden opnemen in het onderwijsprogramma, wordt weergegeven in figuur 2.3. Deze laat zien dat de grootste groep oud-studenten 
tevreden is over de verhouding tussen gerichtheid op praktijkervaring en theoretische gerichtheid van de opleiding. Bij de andere oud-studenten bestaat een lichte voorkeur voor meer praktijkervaring inbouwen in het curriculum (32\%) boven het opnemen van meer theoretische vakken (21\%).

\section{Oriëntatie op vaardigheden}

De meeste oud-studenten Geneeskunde zijn tevreden over de verhouding tussen theorie en vaardigheden in de opleiding (figuur 2.4): 53\% zou het curriculum, wat de verhouding tussen theorie en vaardigheden betreft, niet aanpassen. Binnen degenen die het curriculum wel zouden aanpassen, vormen de voorstanders van meer theorie in het curriculum $(32 \%)$ een duidelijk grotere groep dan de voorstanders van meer vaardigheden $(16 \%)$.

Figuur 2.4

Meer theorie versus meer vaardigheden gewenst, FdG (\%)

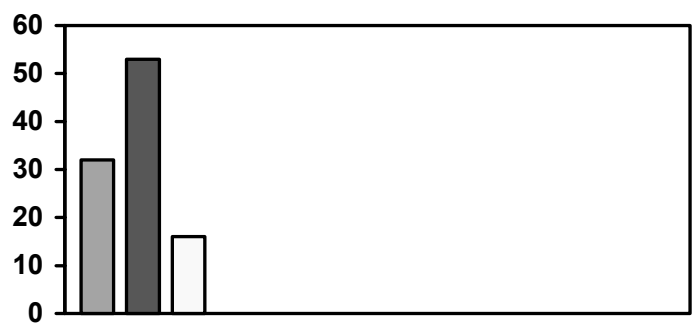

$\square$ meer theorie

niet aanpassen

口meer vaardigheden

\section{Soort vaardigheden}

Wanneer we kijken naar het soort vaardigheden dat oud-studenten zouden willen kiezen, dan zien we in figuur 2.5 dat nagenoeg evenveel oud-studenten de voorkeur geven aan meer beroepsspecifieke vaardigheden (28\%) als aan meer algemene vaardigheden (23\%). De grootste groep echter (49\%) zou het curriculum niet aanpassen wat de oriëntatie op algemene dan wel beroepsspecifieke vaardigheden betreft.

Figuur 2.5

Meer algemene versus meer beroepsspecifieke vaardigheden gewenst, FdG (\%)

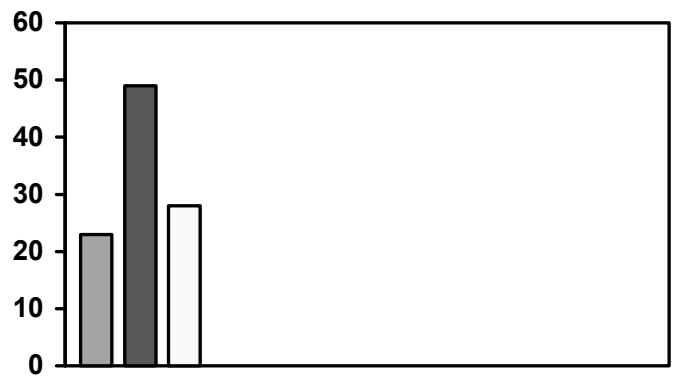

$$
\begin{aligned}
& \square \text { meer algemene } \\
& \text { vaardigheden } \\
& \square \text { niet aanpassen } \\
& \square \text { meer beroepsspecifieke } \\
& \text { vaardigheden }
\end{aligned}
$$


Vrijheid bij vakkenkeuze

Figuur 2.6 toont de voorkeur van oud-studenten Geneeskunde ten aanzien van de vrijheid bij het samenstellen van het vakkenpakket. Over de vrijheid van vakkenkeuze is de overgrote meerderheid $(69 \%)$ van de geënquêteerde oud-studenten tevreden. Binnen de minderheid die ontevreden is over de vrijheid van vakkenkeuze, vormen de voorstanders van meer keuzevrijheid $(21 \%)$ een grotere groep dan degenen die vinden dat er minder vrijheid moet zijn in de keuze van vakken (10\%).

Figuur 2.6

Gewenste vrijheid bij vakkenkeuze, FdG (\%)
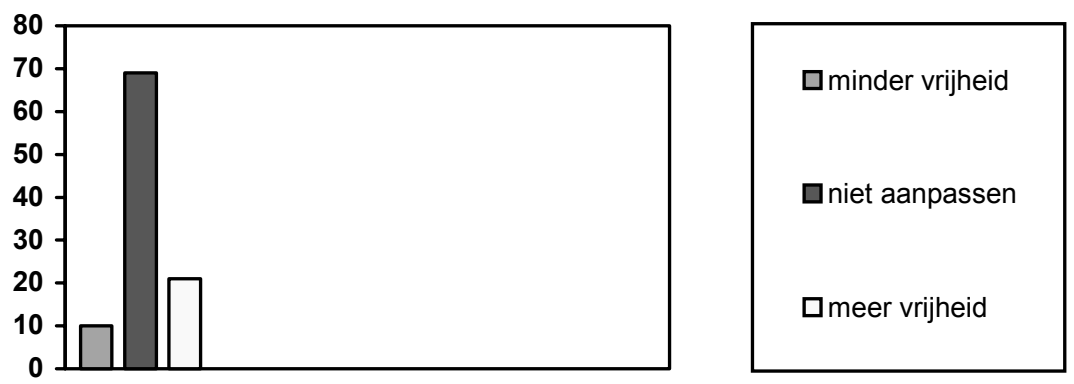

\section{Moeilijkheidsgraad}

Vooral ten gevolge van de verdergaande stijging van de opleidingseisen binnen veel beroepsgroepen is de vraag naar hoger opgeleiden de afgelopen jaren sterk toegenomen. Uit internationaal onderzoek blijkt dat met name de toenemende internationalisering en de daaraan gerelateerde organisatorische veranderingen een belangrijke oorzaak vormen van de toegenomen kwalificatievereisten. De snelle technologische ontwikkelingen leiden tot een toenemende complexiteit van veel functies. Daarnaast bewerkstelligen technologische ontwikkelingen vaak ook organisatorische veranderingen, zoals het schrappen van managementlagen, decentralisering, 'empowerment', e.d. die op hun beurt de kwalificatie-eisen verder doen stijgen. Een belangrijke rol speelt daarbij dat massaproductie in alle sectoren plaats maakt voor op de consument afgestemd maatwerk en een toenemend belang van de kwaliteit van de geleverde goederen en diensten. Het laatste resulteert in de toegenomen aandacht voor kwaliteitszorg, die doorgaans leidt tot meer aandacht voor het belang van goed geschoold personeel (ROA, 1999, blz. 6).

De toenemende kwalificatie-eisen verklaren wellicht waarom niemand van de geënquêteerde oud-studenten Geneeskunde een minder zwaar studieprogramma voorstaat. In tegendeel, de helft (49\%) is van mening dat het curriculum best zwaarder mag zijn (figuur 2.7). De andere helft (51\%) van de oud-studenten is tevreden over de zwaarte van het studieprogramma en wil deze dan ook niet aanpassen. 
Bij deze bevindingen dient te worden opgemerkt dat dit de mening van afgestudeerden betreft, dus van degenen die de opleiding aan de UM destijds met diploma hebben voltooid. Oud-studenten die destijds hun opleiding voortijdig hebben verlaten zullen wellicht een andere mening zijn toegedaan.

Figuur 2.7

Gewenste zwaarte van het studieprogramma, FdG (\%)
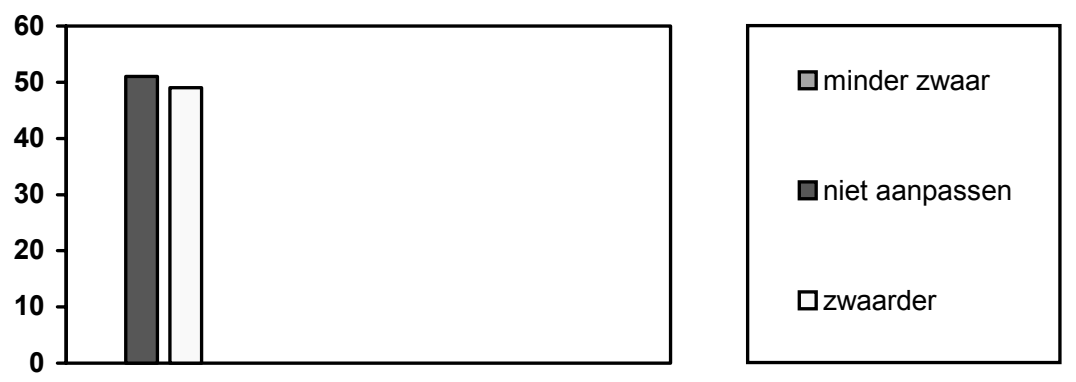

\section{Buitenlandoriëntatie}

In het licht van de toenemende internationalisering van onze samenleving bieden universiteiten aan studenten steeds vaker de mogelijkheid om een deel van de studie, een stage of een project in het buitenland te volgen. Buitenlandervaring, opgedaan tijdens de opleiding, kan van belang zijn voor de wijze waarop de transitie van studie naar werk en de verdere ontwikkeling van de beroepscarrière verloopt. Zo blijkt uit onderzoek onder universitaire afgestudeerden dat oud-studenten die tijdens hun opleiding buitenlandervaring hebben opgedaan veel vaker op zoek gaan naar werk in het buitenland en ook vaker daadwerkelijk in het buitenland gaan werken dan oud-studenten zonder buitenlandervaring (Meng \& Ramaekers, 2000). Uit het onderzoek van Meng en Ramaekers onder universitaire afgestudeerden blijkt verder dat buitenlandervaring tijdens de opleiding bij afgestudeerden van economische en technische opleidingen tot een verhoging van hun productieve waarde leidt.

Figuur 2.8

Gewenste buitenlandervaring in de opleiding, FdG (\%)

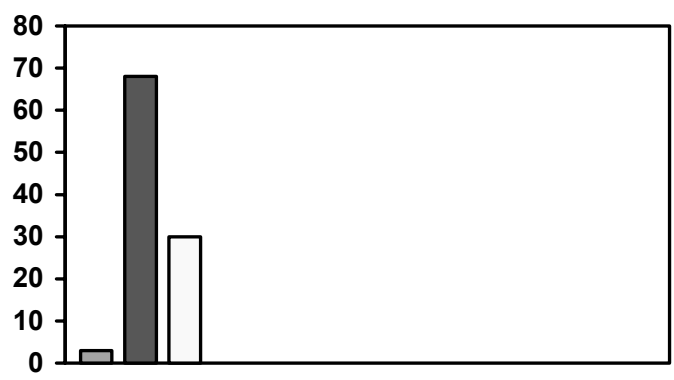


Wat de gewenste aanpassingen van de opleiding betreft, is ten slotte gevraagd naar de mate waarin naar de mening van de oud-studenten buitenlandervaring moet worden ingebouwd in het opleidingsprogramma (figuur 2.8). De overgrote meerderheid $(68 \%)$ van de geënquêteerde oud-studenten Geneeskunde is tevreden over de mate waarin de opleiding voorziet in het opdoen van buitenlandervaring. Bijna een derde $(30 \%)$ van de oud-studenten wenst meer buitenlandervaring in de opleiding, terwijl vrijwel niemand $(3 \%)$ de buitenlandervaring wil reduceren.

\subsection{Oordeel over voorbereiding op beroepspraktijk}

\section{Oordeel over startbekwaamheid en potentieel voor verdere ontwikkeling}

Aan de oud-studenten is gevraagd om op een vijfpuntschaal (van 'zeer oneens' $t / m$ 'zeer eens') aan te geven in welke mate zij het eens zijn met de stelling dat de opleiding hen startbekwaam heeft gemaakt voor de arbeidsmarkt en een basis heeft verschaft om zich beroepsmatig verder te ontwikkelen. Tabel 2.6 toont het procentuele aandeel van de oud-studenten, die de stelling onderschrijven dat de opleiding een goede basis biedt (antwoordcategorie 4 of 5) om te starten op de arbeidsmarkt respectievelijk kennis en vaardigheden verder te ontwikkelen.

Tabel 2.6

Oordeel over de voorbereiding op de beroepspraktijk, FdG: \% (zeer) met stelling eens*

- $\quad$ De kennis en vaardigheden die ik tijdens de opleiding heb verworven, zijn voldoende om adequaat te starten in de beroepspraktijk

De opleiding biedt voldoende basis voor het verder ontwikkelen van kennis en vaardigheden

* Percentage oud-studenten dat 4 of 5 scoort op een schaal van 1 (zeer oneens) t/m 5 (zeer eens).

Hoewel een ruime meerderheid van de geënquêteerde oud-studenten Geneeskunde vindt dat de opleiding hen voldoende heeft toegerust om adequaat te kunnen starten in de beroepspraktijk, is een op de drie oud-studenten - achteraf terugblikkend - van mening dat hun startbekwaamheid onvoldoende was. Dit hoeft overigens niet problematisch te zijn geweest voor hun verdere beroepsmatige ontwikkeling. Immers, vrijwel alle respondenten Geneeskunde vinden - achteraf terugblikkend - dat de opleiding een voldoende basis heeft geboden om kennis en vaardigheden verder te kunnen ontwikkelen, bijvoorbeeld via nascholing.

In tabel 2.7 wordt de startbekwaamheid nader gespecificeerd door na te gaan in hoeverre oud-studenten Geneeskunde bij de overgang naar de beroepspraktijk tekorten in theoretische kennis, praktische vaardigheden en omgang met praktijkproblemen/-situaties hebben ervaren. Vervolgens wordt in tabel 2.8 nagegaan of nascholing nodig was vanwege tekortkomingen in de opleiding. 
Bij de start op de arbeidsmarkt ervaren opleidingstekorten

Aan de oud-studenten zijn drie stellingen voorgelegd, die verwijzen naar eventuele tekorten in theoretische kennis, praktische vaardigheden en praktijkervaring die zij bij de overgang naar de beroepspraktijk hebben ervaren. Tabel 2.7 toont hoeveel procent van de oud-studenten het met de drie stellingen eens is (antwoordcategorie 4 of 5 , gemeten op een vijfpuntschaal van: 'zeer oneens' $t / m$ 'zeer eens').

Vier op de tien oud-studenten Geneeskunde (38\%) geven aan dat ze bij de overgang naar de beroepspraktijk tekorten hebben ervaren in theoretische kennis. Daar staat tegenover dat 'slechts' $13 \%$ aangeeft dat ze bij de overgang naar de beroepspraktijk tekorten hebben ervaren in praktische vaardigheden. Ook vindt de meerderheid dat zij tijdens de opleiding voldoende in aanraking zijn geweest met praktijkproblemen en praktijksituaties.

Tabel 2.7

Ervaren tekorten bij de overgang naar de beroepspraktijk, FdG: \% (zeer) met stelling eens

- $\quad$ Bij de overgang naar de beroepspraktijk heb ik tekorten ervaren in theoretische kennis

- $\quad$ Bij de overgang naar de beroepspraktijk heb ik tekorten ervaren in praktische vaardigheden

- $\quad$ Tijdens mijn opleiding ben ik voldoende in aanraking geweest met praktijkproblemen en praktijksituaties

* Percentage oud-studenten dat 4 of 5 scoort op een schaal van 1 (zeer oneens) t/m 5 (zeer eens).

\section{Belang van nascholing}

$\mathrm{Na}$ het afstuderen houdt het verwerven van kennis en vaardigheden niet op. Mede gezien de veranderingen in de arbeidsmarkt en de daaruit voortkomende veranderingen in de gewenste competenties, mag worden verwacht dat er behoefte blijft bestaan aan bijscholing.

Aan de oud-studenten zijn drie stellingen voorgelegd, die betrekking hebben op de noodzaak van nascholing. Tabel 2.8 toont hoeveel procent van de oud-studenten het met de drie stellingen eens is (antwoordcategorie 4 of 5 , gemeten op een vijfpuntschaal van: 'zeer oneens' $t / m$ 'zeer eens').

Tabel 2.8

Oordeel over de relevantie van nascholing, FdG: \% (zeer) met stelling eens*

\footnotetext{
Nascholing is nodig vanwege tekortkomingen in mijn opleiding

Nascholing is nodig om kennis en vaardigheden op te doen die beter te leren zijn in combinatie met werk

Nascholing is nodig vanwege nieuwe ontwikkelingen die niet te voorzien waren tijdens mijn opleiding

* Percentage oud-studenten dat 4 of 5 scoort op een schaal van 1 (zeer oneens) t/m 5 (zeer eens).
} 
In tabel 2.6 hebben we kunnen zien dat de meeste oud-studenten Geneeskunde vinden dat de opleiding hen voldoende heeft toegerust om adequaat te kunnen starten in de beroepspraktijk. Het is dan ook niet verwonderlijk dat 'slechts' een op de drie oud-studenten de stelling onderschrijft dat nascholing nodig is vanwege tekortkomingen in de opleiding.

Met betrekking tot de noodzaak van nascholing zijn oud-studenten Geneeskunde het vaakst van mening dat nascholing nodig is vanwege nieuwe ontwikkelingen die niet te voorzien zijn tijdens de opleiding, of om kennis en vaardigheden op te doen die beter te leren zijn in combinatie met werk. Uit onderzoek van het ROA is gebleken dat bijvoorbeeld managementvaardigheden beter te leren zijn in combinatie met werk dan in het initiële onderwijs (Heijke, Meng \& Ramaekers, 2003, Heijke, Ramaekers \& Ris, 2004).

\subsection{Conclusies en aanbevelingen}

Aan het onderzoek hebben 47 oud-studenten Geneeskunde deelgenomen, wat neerkomt op een respons van $31 \%$. Bij drie opleidingspecifieke competenties, te weten het vermogen om op de hoogte te blijven van nieuwe medische ontwikkelingen, nieuwe medische inzichten te gebruiken en medisch handelen wetenschappelijk te onderbouwen, schatten de respondenten hun eigen niveau iets lager in dan het niveau dat vereist is in hun functie. Toch hoeft de opleiding aan deze competenties volgens de geënquêteerde oud-studenten niet meer aandacht te besteden. Dit komt omdat deze competenties voornamelijk ná de opleiding worden opgedaan, en wel via nascholing die volgens de oud-studenten nodig is vanwege nieuwe ontwikkelingen die niet te voorzien zijn tijdens de opleiding. Wel vinden de geënquêteerde oud-studenten dat de opleiding meer aandacht zou moeten besteden aan het vermogen om onder druk goed te functioneren, leiding te geven en informatie- \& communicatietechnologie te gebruiken.

Over de wijze waarop de opleiding hen heeft voorbereid op de beroepspraktijk zijn negen van de tien oud-studenten Geneeskunde tevreden. Vooral over de nadruk die in de opleiding wordt gelegd op onderwijsgroepen, vaardigheidstrainingen, practica en patiëntencontacten is een overduidelijke meerderheid van de geënquêteerde oudstudenten Geneeskunde tevreden. De stage als voorbereiding op de beroepspraktijk wordt door een ruime meerderheid positief beoordeeld. Vrijwel iedereen ziet de stage als een meerwaarde voor de opleiding. Echter, op presenteren zou volgens acht van de tien oud-studenten méér nadruk gelegd moeten worden.

Van de onderzochte oud-studenten is de grootste groep tevreden over de opleiding wat betreft de gerichtheid op praktijk versus theorie, de verhouding tussen theorie en vaardigheden, de oriëntatie op algemene dan wel beroepsspecifieke vaardigheden, de vrijheid van vakkenkeuze en de mate waarin de opleiding voorziet in het opdoen van buitenlandervaring. Er zijn echter wel een paar punten die oud-studenten zouden willen aanpassen in de oriëntatie van het curriculum. Ten eerste, zou een bredere opzet van het curriculum volgens de grootste groep oud-studenten een verbetering zijn. Een tweede punt van aandacht is dat de grootste groep oud-studenten de 
voorkeur geeft aan een meer beroepsgerichte oriëntatie van het curriculum. Over de gewenste zwaarte van het curriculum zijn de oud-studenten verdeeld: de ene helft is tevreden over zwaarte van het studieprogramma, terwijl de andere helft vindt dat het curriculum best zwaarder mag zijn.

De meeste oud-studenten Geneeskunde vinden dat de opleiding hen voldoende heeft toegerust om adequaat te kunnen starten in de beroepspraktijk. Dit laat onverlet dat vier van de tien respondenten Geneeskunde aangeven dat ze bij de overgang naar de beroepspraktijk tekorten hebben ervaren in theoretische kennis. Daar staat tegenover dat de meeste respondenten bij de overgang naar de beroepspraktijk geen tekorten hebben ervaren in praktische vaardigheden, noch in ervaring met praktijkproblemen en praktijksituaties. Het is dan ook niet verwonderlijk dat 'slechts' een op de drie oud-studenten vindt dat nascholing nodig is vanwege tekortkomingen in de opleiding.

Vrijwel alle geënquêteerde oud-studenten zijn van mening dat de opleiding een goede basis heeft gelegd voor de verdere ontwikkeling van competenties. De overgrote meerderheid van de respondenten is dan ook van mening dat nascholing nodig is vanwege nieuwe ontwikkelingen die niet te voorzien zijn tijdens de opleiding, of om kennis en vaardigheden op te doen die beter te leren zijn in combinatie met werk.

Kort samengevat luiden de aanbevelingen ${ }^{2}$ van de geënquêteerde oud-studenten Geneeskunde voor aanpassingen in het curriculum:

- Liever streven naar een breder curriculum dan naar een meer specialistisch curriculum;

- Liever streven naar een meer beroepsgericht curriculum dan naar een meer academisch gericht curriculum;

- In de opleiding een zwaarder accent leggen op het geven van presentaties/ voordrachten;

- $\quad$ In de opleiding meer aandacht besteden aan het vermogen om onder druk goed te functioneren en informatie- \& communicatietechnologie te gebruiken. Hierbij zij opgemerkt dat oud-studenten ook aanbevelen om meer aandacht te besteden aan het vermogen om leiding te geven. Echter, bij deze competentie blijkt hun niveau toereikend te zijn voor het niveau dat vereist is in hun functie.

2. De hier gepresenteerde aanbevelingen zijn niet geordend naar belangrijkheid. 



\section{Resultaten Faculteit der Rechtsgeleerdheid}

In dit hoofdstuk worden de resultaten besproken van het eind 2003 uitgevoerde curriculumonderzoek onder oud-studenten van afstudeerjaargang 1996/1997. De resultaten hebben dus betrekking op oud-studenten die op het moment van de enquête zo'n zes jaar op de arbeidsmarkt vertoeven. Op de enquête hebben in totaal 58 oud-studenten Rechtsgeleerdheid gerespondeerd (respons 22\%). De analyse is echter beperkt tot de 35 oud-studenten Rechtsgeleerdheid die werkzaam zijn in functies op universitair niveau, waarvoor de eigen of een verwante opleidingsrichting is vereist. Dit is gedaan om te voorkomen dat de opleiding mede wordt 'afgerekend' op het oordeel van oud-studenten, die werkzaam zijn in functies waarvoor de opleiding niet beoogde op te leiden.

In de enquête is aan de oud-studenten gevraagd om een aantal aspecten van hun opleiding te evalueren. Deze aspecten betreffen achtereenvolgens de competenties waarover oud-studenten (dienen te) beschikken en de aandacht die de opleiding hieraan zou moeten besteden (paragraaf 3.1), de nadruk die oud-studenten zouden leggen op verschillende didactische werkvormen (paragraaf 3.2), het nut dat oudstudenten toekennen aan de studieonderdelen scriptie en stage (paragraaf 3.3), de accenten die oud-studenten zouden leggen in de gerichtheid van het curriculum op een aantal aspecten (paragraaf 3.4), hun oordeel over de mate waarin de opleiding hen heeft voorbereid op de beroepspraktijk en het belang van nascholing hierbij (paragraaf 3.5). Tot slot worden in paragraaf 3.6 de belangrijkste bevindingen samengevat in de vorm van een aantal conclusies en aanbevelingen.

\subsection{Competenties}

\section{Waarom meting van competenties?}

Er zijn verschillende redenen om onderzoek naar competenties van hoger opgeleiden verder te ontwikkelen. In de eerste plaats kunnen gegevens over competenties worden gebruikt voor het bewaken en verbeteren van de kwaliteit van opleidingen in termen van de mate waarin zij afgestudeerden hebben voorbereid op de beroepspraktijk. Dezelfde gegevens kunnen ook worden gebruikt om effecten van veranderingen in het hoger onderwijs te evalueren, zoals de invoering van het bamastelsel. Tot slot kunnen gegevens over competenties helpen om meer inzicht te krijgen in hoe de arbeidsmarkt werkt. Hieronder wordt nader ingegaan op deze drie redenen om competenties te meten.

Tegen de achtergrond van de invoering van een systeem van accreditering in het kader van de kwaliteitszorg van het hoger onderwijs, is de laatste jaren een verschuiving waar te nemen in de informatiebehoefte van degenen die zich bezig houden met diverse aspecten van de kwaliteit van het hoger onderwijs. Werd in het verleden meer naar de inputfactoren en het onderwijsproces zelf gekeken, thans wordt meer het accent gelegd op de eindtermen en de gewenste output van opleidingen. Hierbinnen is ook een verschuiving opgetreden, van de onderwijs- 
prestaties zelf (geïndiceerd door bijvoorbeeld eindexamenresultaten) naar de competenties waarover afgestudeerden (dienen te) beschikken. De redenering hierbij is simpel: "the proof of the pudding is in the eating", en opleidingen kunnen het beste hun kwaliteit aantonen middels de geschiktheid van de afgestudeerden om in de praktijk te functioneren.

Een tweede reden om zicht te krijgen op de competenties van afgestudeerden betreft de invoering van de bachelor-master structuur. Deze raakt de verhouding in oriëntatie tussen het hoger beroepsonderwijs en het wetenschappelijk onderwijs, en de differentiatie in twee uitstroomniveaus. Het meten van competenties is in dit kader van belang voor het ontwikkelen van een transparante kwalificatiestructuur van het hoger onderwijs en voor de organiseerbaarheid van het hoger onderwijs.

Naast bovengenoemde institutionele redenen is meting van competenties uit wetenschappelijk oogpunt relevant, omdat hiermee een beter inzicht in de werking van de arbeidsmarkt kan worden verkregen. Over de betekenis van onderwijs voor het latere beroepsmatig functioneren bestaan verschillende theorieën. Deze verschillen enerzijds met betrekking tot de vraag in hoeverre competenties in het onderwijs worden opgedaan (en zo ja welke competenties), en anderzijds met betrekking tot de vraag welke rol competenties spelen bij selectie, allocatie en beloning van werkenden. Een tweede punt van discussie betreft de vraag wat voor soort competenties op de arbeidsmarkt worden gevraagd. Wat is het relatieve belang van specifieke competenties ten opzichte van de meer generieke competenties? Worden in de transitiefase van school naar werk andere competenties gevraagd dan in latere fasen van de loopbaan? Welke competenties hebben oud-studenten nodig om snel productief inzetbaar te zijn (startbekwaam) en welke competenties verzekeren hun employability op langere termijn? Wat betekent dit voor het curriculum? Deze vragen zijn van wezenlijk belang, niet alleen vanuit theoretische optiek maar ook om te komen tot een meer effectieve en efficiënte inrichting van het onderwijs.

Tegen de bovengeschetste achtergrond is aan alle oud-studenten een lijst voorgelegd van 31 generieke competenties die in het werk van belang kunnen zijn. Deze lijst van generieke competenties is voor oud-studenten Rechtsgeleerdheid uitgebreid met 7 opleidingspecifieke competenties.

Aan de oud-studenten is gevraagd om voor iedere competentie een inschatting te geven van achtereenvolgens:

- $\quad$ het niveau dat vereist is in hun huidige functie;

- $\quad$ hun eigen niveau;

- $\quad$ waar zij de competentie vooral hebben geleerd.

Zowel het vereiste als het eigen niveau konden zij aangeven op een vijfpuntschaal (van 'relatief laag' $t / m$ 'relatief hoog'). De belangrijkste leerbron van de competentie konden zij aangeven op een vijfpuntschaal (van 'buiten de WO-opleiding' $t / m$ 'in de WO-opleiding'). 


\section{Vereist niveau van competenties}

Kolom 2 van tabel 3.1 toont voor iedere competentie welk percentage van de betaald werkende oud-studenten het in de functie vereiste niveau als hoog inschat (antwoordcategorie 4 of 5 ).

Tabel 3.1

Vereist en eigen competentieniveau, FdR (\% hoog niveau*)

Vereist niveau Eigen niveau

Kennis van:

het eigen vakgebied

andere vakgebieden

86

Vermogen om:

vakkennis in de praktijk toe te passen

problemen te analyseren en op te lossen

verbanden te leggen tussen verschillende zaken

hoofdzaken van bijzaken te onderscheiden

logisch te redeneren

conform budget en planning te werken

onder druk goed te functioneren

besluiten te nemen

nieuwe ideeën en oplossingen te bedenken

continue te leren

aan anderen duidelijk te maken wat $u$ bedoelt

met anderen samen te werken

leiding te geven

zelfstandig te werken

in conflictsituaties adequaat te reageren

presentaties te geven

gesprekken te voeren

rapporten en brieven te schrijven

in buitenlandse talen te communiceren

ICT te gebruiken

Bereidheid om:

werkgerelateerde risico's te nemen

ideeën van uzelf en anderen ter discussie te stellen

op te komen voor uw eigen standpunt

begrip te tonen voor andere standpunten

verantwoordelijkheid te nemen

kritisch na te denken over uw eigen handelen

uw gedrag aan te passen aan de situatie

feedback te ontvangen en te geven

Vermogen om (opleidingspecifiek):

processtukken op te stellen (dagvaarding, conclusies)

een pleitnota te kunnen schrijven

$63 \quad 65$

- $\quad$ relevante jurisprudentie op te zoeken, te interpreteren en toe te passen

te onderhandelen met wederpartij

besprekingen te voeren met cliënten

om te gaan met media

* Percentage oud-studenten dat 4 of 5 scoort op een schaal van 1 (relatief laag) t/m 5 (relatief hoog). 
Van de opleidingspecifieke competenties moeten oud-studenten Rechtsgeleerdheid het vaakst op een hoog niveau beschikken over het vermogen om relevante jurisprudentie op te zoeken, te interpreteren en toe te passen. Minder oud-studenten - alhoewel nog steeds meer dan de helft - moeten op een hoog niveau in staat zijn om processtukken op te stellen, een pleidooi te houden, een pleitnota te schrijven, te onderhandelen met wederpartij en besprekingen te voeren met cliënten. Slechts een op de tien oud-studenten Rechtsgeleerdheid moet op een hoog niveau kunnen omgaan met media.

Kijken we naar de generieke competenties, dan moeten tenminste negen van de tien oud-studenten Rechtsgeleerdheid op een hoog niveau beschikken over:

- het vermogen om vakkennis in de praktijk toe te passen en informatie te vergaren;

- $\quad$ het vermogen om logisch te redeneren;

- analytische competenties (vermogen om problemen te analyseren en op te lossen, en hoofdzaken van bijzaken te onderscheiden);

- communicatieve competenties (vermogen om aan anderen duidelijk te maken wat men bedoelt en rapporten en brieven te schrijven);

- $\quad$ het vermogen om zelfstandig te werken.

\section{Eigen niveau van de competenties}

Kolom 3 van tabel 3.1 toont voor iedere competentie welk percentage van de oudstudenten het eigen niveau als hoog inschat (antwoordcategorie 4 of 5).

Van de opleidingspecifieke competenties schatten de geënquêteerde oud-studenten Rechtsgeleerdheid hun vermogen om relevante jurisprudentie op te zoeken, te interpreteren en toe te passen het vaakst als hoog in. Ruim $90 \%$ vindt dat zij deze competentie op een hoog niveau beheersen. Het minst vaak schatten zij hun vermogen om met media om te gaan als hoog in.

Met betrekking tot de generieke competenties, schat minder dan de helft van de onderzochte oud-studenten hun kennis van andere vakgebieden en hun vermogen om conform budget en planning te werken, leiding te geven, presentaties te geven, en in buitenlandse talen te communiceren als hoog in.

\section{Discrepanties tussen vereist niveau en eigen niveau van competenties}

De discrepantie tussen het vereiste niveau en het aanwezige niveau van competenties geeft per competentieaspect een indicatie voor eventuele tekorten of overschotten, en kan daarmee licht werpen op de vraag in hoeverre opleidingen van de UM de kwaliteit leveren die op de arbeidsmarkt van hen wordt verlangd.

De vergelijking van het 'eigen' competentieniveau met het competentieniveau dat vereist is in de functie (tabel 3.1) laat zien dat verschillen tussen vereist en eigen competentieniveau doorgaans zeer gering zijn. Bij de opleidingspecifieke competenties manifesteren zich zelfs nauwelijks of geen discrepanties. Het grootste verschil 
manifesteert zich bij het vermogen om in buitenlandse talen te communiceren. Bij deze competentie ligt het niveau van de oud-studenten duidelijk hoger dan het niveau dat vereist is in hun functie.

In het licht van het vereiste en het 'eigen' competentieniveau wordt in tabel 3.3 nagegaan in hoeverre de aandacht die de opleiding aan competenties besteedt volgens de oud-studenten zou moeten worden bijgesteld. Echter, aangezien competenties slechts ten dele binnen het initieel onderwijs worden opgedaan, wordt eerst in tabel 3.2 nagegaan in welke mate oud-studenten de competenties vooral in de initiële WO-opleiding hebben opgedaan.

Tabel 3.2

Belangrijkste leerbron van competenties, FdR (\% in de WO-opleiding*)

Kennis van:

- het eigen vakgebied $\quad 34$

andere vakgebieden 16

Vermogen om:

- $\quad$ vakkennis in de praktijk toe te passen $\quad 43$

informatie te vergaren 60

problemen te analyseren en op te lossen 63

verbanden te leggen tussen verschillende zaken $\quad 50$

hoofdzaken van bijzaken te onderscheiden 50

logisch te redeneren $\quad 52$

conform budget en planning te werken 3

onder druk goed te functioneren

besluiten te nemen 6

nieuwe ideeën en oplossingen te bedenken $\quad 20$

continue te leren $\quad 40$

aan anderen duidelijk te maken wat $\mathrm{u}$ bedoelt $\quad 27$

met anderen samen te werken 35

leiding te geven 12

zelfstandig te werken $\quad 47$

in conflictsituaties adequaat te reageren $\quad 12$

presentaties te geven 15

gesprekken te voeren $\quad 27$

$\begin{array}{ll}\text { rapporten en brieven te schrijven } & 21\end{array}$

in buitenlandse talen te communiceren 15

ICT te gebruiken

Bereidheid om:

werkgerelateerde risico's te nemen

ideeën van uzelf en anderen ter discussie te stellen

op te komen voor uw eigen standpunt 38

begrip te tonen voor andere standpunten $\quad 24$

verantwoordelijkheid te nemen $\quad 18$

$\begin{array}{ll}\text { kritisch na te denken over uw eigen handelen } & 21\end{array}$

uw gedrag aan te passen aan de situatie $\quad 15$

feedback te ontvangen en te geven 21

Vermogen om (opleidingspecifiek):

processtukken op te stellen (dagvaarding, conclusies) 18

een pleidooi te kunnen houden 15

een pleitnota te kunnen schrijven 18

relevante jurisprudentie op te zoeken, te interpreteren en toe te passen 68

te onderhandelen met wederpartij 9

besprekingen te voeren met cliënten 12

om te gaan met media

* Percentage oud-studenten dat 4 of 5 scoort op een schaal van 1 (buiten de WO-opleiding) $\mathrm{t} / \mathrm{m} 5$ (in de WO-opleiding). 


\section{Belangrijkste leerbron van competenties}

Competenties worden niet alleen tijdens het volgen van een initiële opleiding opgedaan maar ook na het afstuderen, bijvoorbeeld in postdoctorale beroepsopleidingen en cursussen of tijdens de uitoefening van een beroep. Aan de oudstudenten is gevraagd om voor iedere competentie aan te geven waar zij de betreffende competentie vooral hebben geleerd. Zij konden dit aangeven op een vijfpuntschaal (van 1 'buiten de WO-opleiding' t/m 5 'in de WO-opleiding'). Tabel 3.2 toont voor iedere competentie welk percentage van de oud-studenten aangeeft dat de betreffende competentie vooral in de WO-opleiding is opgedaan (antwoordcategorie 4 of 5 ).

De tabel laat zien dat de meeste competenties voornamelijk buiten of na de opleiding zijn verworven. Slechts één opleidingspecifieke competentie en drie generieke competenties zijn door meer dan de helft van de oud-studenten vooral in de initiële opleiding opgedaan, namelijk het vermogen om relevante jurisprudentie op te zoeken, te interpreteren en toe te passen, informatie te vergaren, problemen te analyseren en op te lossen, en logisch te redeneren. Deze competenties moeten overigens zeer vaak op een hoog niveau worden beheerst (tabel 3.1).

Generieke competenties die vrijwel uitsluitend (door meer dan $90 \%$ van de oudstudenten) buiten of na de opleiding worden opgedaan, zijn het vermogen om conform budget en planning te werken, onder druk goed te functioneren, besluiten te nemen, informatie- \& communicatietechnologie te gebruiken en de bereidheid om werkgerelateerde risico's te nemen. Hetzelfde is het geval met het (opleidingspecifieke) vermogen om te onderhandelen met wederpartijen en om te gaan met media.

\section{Mening over bestede aandacht aan competenties}

In tabel 3.3 wordt nagegaan of de generieke en opleidingspecifieke competenties volgens de oud-studenten wel voldoende aan bod zijn gekomen tijdens hun WOopleiding. Daartoe is aan de oud-studenten gevraagd om van de generieke en opleidingspecifieke competenties er maximaal 3 te noemen waarvan zij vonden dat deze in hun WO-opleiding te weinig aan bod zijn gekomen, en die dus volgens hen meer aandacht hadden moeten krijgen. Aangezien meer aandacht voor de ene competentie, bij een gelijkblijvende studieduur, minder aandacht voor een andere competentie betekent, is aan de oud-studenten ook gevraagd om maximaal 3 competenties te noemen die naar hun mening te veel aan bod zijn gekomen. Tabel 3.3 toont de scores van oud-studenten Rechtsgeleerdheid op beide vragen.

Als eerste valt op dat de geënquêteerde oud-studenten Rechtsgeleerdheid slechts bij één competentie duidelijk verdeeld zijn in hun mening over de mate waarin deze in hun opleiding aan bod is gekomen. Zo noemt $11 \%$ het vermogen om rapporten en brieven te schrijven als één van de drie competenties die te veel aan bod zijn gekomen tijdens de opleiding Rechtsgeleerdheid, terwijl een nagenoeg gelijk 
percentage (namelijk $7 \%$ ) deze competentie noemt als één van de drie die te weinig aan bod zijn gekomen.

Tabel 3.3

Oordeel over de mate waarin competenties aan bod komen tijdens de opleiding, FdR (\%)

\begin{tabular}{|c|c|c|c|}
\hline & $\begin{array}{l}\text { Te veel } \\
\text { aan bod }\end{array}$ & $\begin{array}{l}\text { Te weinig } \\
\text { aan bod }\end{array}$ & $\begin{array}{l}\text { Saldo (te veel } \\
\text { - te weinig) }\end{array}$ \\
\hline \multicolumn{4}{|l|}{ Kennis van: } \\
\hline - $\quad$ het eigen vakgebied & 11 & 0 & 11 \\
\hline - $\quad$ andere vakgebieden & 0 & 4 & -4 \\
\hline \multicolumn{4}{|l|}{ Vermogen om: } \\
\hline - vakkennis in de praktijk toe te passen & 0 & 21 & -21 \\
\hline - informatie te vergaren & 11 & 4 & 7 \\
\hline - $\quad$ problemen te analyseren en op te lossen & 22 & 0 & 22 \\
\hline $\begin{array}{l}\text { - verbanden te leggen tussen verschillende } \\
\text { zaken }\end{array}$ & 0 & 4 & -4 \\
\hline hoofdzaken van bijzaken te onderscheiden & 0 & 0 & 0 \\
\hline logisch te redeneren & 0 & 0 & 0 \\
\hline - $\quad$ conform budget en planning te werken & 0 & 11 & -11 \\
\hline - $\quad$ onder druk goed te functioneren & 0 & 7 & -7 \\
\hline - besluiten te nemen & 0 & 14 & -14 \\
\hline - $\quad$ nieuwe ideeën en oplossingen te bedenken & 0 & 7 & -7 \\
\hline continue te leren & 0 & 0 & 0 \\
\hline - $\quad$ aan anderen duidelijk te maken wat $u$ bedoelt & 0 & 4 & -4 \\
\hline - $\quad$ met anderen samen te werken & 11 & 0 & 11 \\
\hline leiding te geven & 0 & 14 & -14 \\
\hline - $\quad$ zelfstandig te werken & 33 & 4 & 29 \\
\hline - in conflictsituaties adequaat te reageren & 0 & 18 & -18 \\
\hline presentaties te geven & 0 & 25 & -25 \\
\hline gesprekken te voeren & 0 & 7 & -7 \\
\hline - $\quad$ rapporten en brieven te schrijven & 11 & 7 & 4 \\
\hline in buitenlandse talen te communiceren & 0 & 18 & -18 \\
\hline ICT te gebruiken & 0 & 11 & -11 \\
\hline \multicolumn{4}{|l|}{ Bereidheid om: } \\
\hline - werkgerelateerde risico's te nemen & 0 & 0 & 0 \\
\hline stellen & 0 & 0 & 0 \\
\hline - $\quad$ op te komen voor uw eigen standpunt & 0 & 0 & 0 \\
\hline - begrip te tonen voor andere standpunten & 0 & 0 & 0 \\
\hline - $\quad$ verantwoordelijkheid te nemen & 0 & 4 & -4 \\
\hline kritisch na te denken over uw eigen handelen & 0 & 0 & 0 \\
\hline uw gedrag aan te passen aan de situatie & 11 & 0 & 11 \\
\hline - feedback te ontvangen en te geven & 0 & 0 & 0 \\
\hline \multicolumn{4}{|l|}{ Vermogen om (opleidingspecifiek): } \\
\hline $\begin{array}{l}\text { concluses) } \\
\text { een pleidooi te kunnen houden }\end{array}$ & 0 & 10 & $\begin{array}{l}-18 \\
-14\end{array}$ \\
\hline - $\quad$ een pleitnota te kunnen schrijven & 0 & 11 & -11 \\
\hline - $\quad$ relevante jurisprudentie op te zoeken, te & & & \\
\hline interpreteren en toe te passen & 33 & 4 & 29 \\
\hline te onderhandelen met wederpartij & 0 & 11 & -11 \\
\hline - $\quad$ besprekingen te voeren met cliënten & 0 & 14 & -14 \\
\hline - om te gaan met media & 0 & 7 & -7 \\
\hline
\end{tabular}


Eén competentie is door tenminste een van de vier respondenten genoemd als één van de drie competenties die te weinig aan bod zijn gekomen tijdens de opleiding Rechtsgeleerdheid, terwijl niemand deze competentie heeft genoemd als één van de drie competenties die te veel aan bod zijn gekomen. Deze 'tekortschietende' competentie betreft het vermogen om presentaties te geven. Wellicht omdat deze competentie te weinig aan bod komt tijdens de opleiding, hebben oud-studenten deze competentie zeer vaak buiten of na de opleiding opgedaan of moeten opdoen (tabel 3.2). Overigens gaat het hierbij om een competentie die door minder dan de helft van de oud-studenten op een hoog niveau moet worden beheerst, en om een competentie waarbij hun eigen niveau toereikend is voor het niveau dat vereist is in hun functie (tabel 3.1). Dit laatste duidt er op dat oud-studenten er vaak in slagen om zich het vermogen om presentaties te geven buiten de opleiding eigen te maken.

Van de opleidingspecifieke competenties heeft het vermogen om relevante jurisprudentie op te zoeken, te interpreteren en toe te passen (meer dan) voldoende aandacht gekregen in de opleiding. Dit verklaart wellicht waarom bij deze voor de beroepsuitoefening zo belangrijke competentie vrijwel alle $(94 \%)$ geënquêteerde oud-studenten hun eigen niveau als hoog inschatten (tabel 3.1). Bij de bevinding dat deze competentie (meer dan) voldoende aandacht heeft gekregen in de opleiding, dient te worden opgemerkt dat deze competentie voornamelijk in de opleiding wordt opgedaan, en niet buiten of na de opleiding (tabel 3.2).

\subsection{Gewenste nadruk op didactische werkvormen}

De werkvormen waarmee studenten tijdens de opleiding in aanraking komen spelen een belangrijke rol bij de competentieverwerving. Naast activerende onderwijsmethoden, zoals PGO, kunnen activerende werkvormen worden aangeboden, waardoor studenten de mogelijkheid krijgen om kennis en vaardigheden toe te passen op complexe problemen en in 'gesimuleerde' praktijksituaties. In de opleiding kan de mogelijkheid worden geboden om kennis in de praktijk te brengen middels bijvoorbeeld vaardigheidstrainingen, practica, schrijfopdrachten en onderzoeksopdrachten. Bransford e.a. (1989) en Glaser (1991) stellen dat het opdoen van ervaring met praktijkproblemen - of simulaties daarvan - een goede voorbereiding vormt op een beroep. Enerzijds leren studenten beter om te gaan met multidisciplinaire situaties of problemen en zijn ze vaker gestimuleerd om multidisciplinaire kennis toe te passen. Anderzijds zijn afgestudeerden die vaker in de gelegenheid zijn geweest om hun kennis en vaardigheden te trainen in een realistische context, beter voorbereid op de beroepspraktijk dan afgestudeerden die minder vaak gebruik hebben gemaakt van actieve werkvormen.

\section{Gewenste nadruk op (activerende) werkvormen}

Aan de oud-studenten is gevraagd om bij negen (activerende) werkvormen aan te geven of hierop tijdens de opleiding minder, gelijk of meer nadruk gelegd zou moeten worden (tabel 3.4). Als eerste valt op dat bij alle in de vragenlijst opgenomen werkvormen vrijwel niemand opteert voor minder nadruk. Dit kan er op duiden dat 
oud-studenten door de bank genomen opteren voor meer 'contacturen' in de opleiding. Helaas was 'zelfstudie' als werkvorm niet opgenomen in de vragenlijst.

Tabel 3.4

Gewenste nadruk op werkvormen, FdR (\%)

\begin{tabular}{lccc}
\hline & Minder nadruk & Gelijke nadruk & Meer nadruk \\
\hline Onderwijsgroepen & 9 & 86 & 6 \\
Hoorcolleges & 0 & 69 & 31 \\
Groepsopdrachten & 6 & 50 & 44 \\
Vaardigheidstrainingen & 0 & 15 & 85 \\
Practica & 3 & 27 & 70 \\
Presentatie/voordracht & 0 & 24 & 77 \\
Computersimulaties/-games & 4 & 52 & 44 \\
Schrijfopdrachten & 0 & 60 & 62 \\
Onderzoeksopdrachten & 0 & 38 & \\
\hline
\end{tabular}

Een overduidelijke meerderheid van de geënquêteerde oud-studenten Rechtsgeleerdheid is tevreden over de nadruk die in de opleiding wordt gelegd op onderwijsgroepen (86\%). Op vaardigheidstrainingen (85\%), presenteren $(77 \%)$ en practica $(70 \%)$ zou volgens een overduidelijke meerderheid van de respondenten méér nadruk gelegd moeten worden.

Enigszins verdeeld zijn de meningen over de gewenste nadruk op onderzoeksopdrachten. De meeste oud-studenten Rechtsgeleerdheid vinden dat de opleiding hier meer nadruk op zou moeten leggen. Echter, bij deze werkvorm is ook ruim een derde van de geënquêteerde oud-studenten tevreden over de nadruk die deze werkvorm heeft gekregen.

De geënquêteerde oud-studenten zijn ook enigszins verdeeld over de gewenste nadruk op hoorcolleges en schrijfopdrachten. Hoewel de meerderheid tevreden is over de nadruk die op deze werkvormen wordt gelegd, vindt tenminste een op de drie respondenten dat hoorcolleges en schrijfopdrachten meer nadruk zouden moeten krijgen.

Duidelijk verdeeld zijn de geënquêteerde oud-studenten Rechtsgeleerdheid over de gewenste nadruk op groepsopdrachten en computersimulaties/-games. Hoewel vijf van de tien oud-studenten tevreden zijn over de nadruk die op deze werkvormen wordt gelegd, vinden vier van de tien oud-studenten dat op groepsopdrachten en computersimulaties/-games meer nadruk zou moeten worden gelegd.

\section{Algemeen oordeel over de wijze van voorbereiding op de beroepspraktijk}

Aan de oud-studenten is ook gevraagd om op een vijfpuntschaal (van 'zeer oneens' $\mathrm{t} / \mathrm{m}$ 'zeer eens') aan te geven in welke mate zij het eens zijn met de uitspraak: "Ik ben over het algemeen tevreden over de wijze waarop de opleiding mij heeft voorbereid op de beroepspraktijk". Gebleken is dat $71 \%$ van de geënquêteerde oud-studenten Rechtsgeleerdheid deze uitspraak onderschrijft (antwoordcategorie 4 en 5). De ruime 
meerderheid is dus tevreden over de wijze waarop de opleiding hen heeft voorbereid op de beroepspraktijk.

\subsection{Oordeel over scriptie en stage}

Aangezien de scriptie en stage belangrijke onderdelen ter voorbereiding op de arbeidsmarkt vormen, worden deze studieonderdelen in dit rapport afzonderlijk besproken. In de enquête zijn twee stellingen over het studieonderdeel scriptie en drie stellingen over het studieonderdeel stage geponeerd. Aan de oud-studenten is gevraagd in hoeverre zij het met de stellingen eens zijn. De antwoorden zijn gemeten op een vijfpuntschaal, lopend van 1 'zeer oneens' tot en met 5 'zeer eens'. In deze paragraaf worden de procentuele aandelen van de oud-studenten gepresenteerd, die het met de desbetreffende stelling eens zijn (antwoordcategorie 4 of 5). Uitgesloten van de percenteerbasis zijn oud-studenten die hebben aangeven dat de desbetreffende stelling voor hen niet van toepassing is.

\section{Scriptie}

Een op de vijf (19\%) oud-studenten Rechtsgeleerdheid die een scriptie hebben geschreven, vindt dat zij aan de hierdoor verkregen vaardigheden voldoende hebben geleerd voor de beroepspraktijk. Bijna de helft (48\%) van hen is van mening dat de scriptie een duidelijke meerwaarde aan de opleiding heeft gegeven.

Tabel 3.5

Oordeel over de scriptie, FdR: \% (zeer) met stelling eens*

- $\quad$ Aan de vaardigheden die ik tijdens de scriptie heb opgedaan, heb ik voldoende geleerd voor de praktijk

- $\quad$ Het schrijven van een scriptie geeft een duidelijke meerwaarde aan de opleiding

${ }^{*}$ Percentage oud-studenten dat 4 of 5 scoort op een schaal van 1 (zeer oneens) t/m 5 (zeer eens).

\section{Stage}

Tabel 3.6 laat zien dat alle geënquêteerde oud-studenten Rechtsgeleerdheid tijdens hun opleiding stage hebben gelopen. Vrijwel iedereen vindt dat de stage een duidelijke meerwaarde geeft aan de opleiding. Wanneer we kijken naar de voorbereiding van de stage op de beroepspraktijk, dan zien we dat ruim de helft van de geënquêteerde oud-studenten Rechtsgeleerdheid van mening is dat zij in de stage voldoende hebben geleerd voor de beroepspraktijk. Wat betreft de frequentie om stage te lopen, vindt ruim de helft van de respondenten dat stages vaker zouden mogen plaatsvinden.

Ten aanzien van stages zij opgemerkt, dat de relevantie hiervan niet alleen ligt in de voorbereiding op de beroepspraktijk maar ook in het opbouwen van een netwerk dat na de opleiding behulpzaam kan zijn bij het vinden van werk. 
Tabel 3.6

Oordeel over de stage, FdR: \% (zeer) met stelling eens*

Stage gelopen 100

In de stage(s) heb ik voldoende geleerd voor de praktijk $\quad 62$

Ik heb vaker stage willen lopen

Het doen van een stage geeft een duidelijke meerwaarde aan de opleiding 92

* Percentage oud-studenten dat 4 of 5 scoort op een schaal van 1 (zeer oneens) t/m 5 (zeer eens).

\subsection{Gewenste inrichting van het curriculum}

In deze paragraaf wordt beschreven op welke wijze oud-studenten Rechtsgeleerdheid het curriculum na een aantal jaren arbeidsmarktervaring zouden willen aanpassen. Aan de oud-studenten is gevraagd stelling te nemen ten aanzien van een aantal curriculumkenmerken. De respondenten dienden daarbij een keuze te maken tussen twee tegengestelde opties. Deze opties stonden aan de linker- en rechterkant op een antwoordschaal van 1 tot en met 7 . Een voorbeeld: "Als ik de opleiding zou mogen aanpassen, dan gaat mijn voorkeur uit naar meer theorie (antwoordcategorie $1 \mathrm{t} / \mathrm{m} \mathrm{3}$ ) of meer vaardigheden (antwoordcategorie $5 \mathrm{t} / \mathrm{m} 7$ )". Wanneer men de opleiding niet zou willen aanpassen diende men antwoordcategorie 4 aan te geven. In deze paragraaf worden figuren gepresenteerd, die aangeven waar de voorkeur van de oud-studenten naar uitgaat.

\section{Mate van specialisatie}

In de discussie over de inrichting van het onderwijs heeft het spanningsveld tussen een brede of een specialistische oriëntatie binnen opleidingen altijd een belangrijke rol gespeeld. Door het curriculum van een opleiding toe te spitsen op een specifiek beroep zijn de afgestudeerden optimaal voorbereid op dit beroep, en zal de productiviteit derhalve hoog zijn. Een nadeel van een dergelijke specialistische invulling van het onderwijs is echter dat de betreffende afgestudeerden sterk afhankelijk worden van de werkgelegenheidsontwikkeling van dit specifieke beroep. Om voldoende flexibiliteit op de arbeidsmarkt te kunnen waarborgen, is het vereist om de studenten breder op te leiden (Borghans \& De Grip, 1999, blz. 3). Daarbij is er in de praktijk, gegeven de beperkte studieduur, sprake van een spanningsveld tussen enerzijds het op een bepaald beroepsdomein gerichte specifieke vaktechnische karakter van een opleiding en anderzijds de competenties die een bredere inzetbaarheid op de arbeidsmarkt bewerkstelligen. In essentie gaat het hier om het spanningsveld tussen productiviteit en flexibiliteit. Tussen deze twee doelstellingen, productiviteit en flexibiliteit, dient een afweging te worden gemaakt (Borghans \& De Grip, 1999, blz. 26-27).

In de discussie over de inrichting van het onderwijs lijkt een golfbeweging te bestaan tussen enerzijds de roep om bredere kwalificaties en anderzijds de roep om beter toegeruste vakspecialisten. Met name de sterke technologische en organisatorische veranderingen van de laatste jaren hebben geleid tot een roep om werknemers met een hoge employability en sleutelkwalificaties, die niet zijn aangewezen op een specifiek beroep maar in een breder beroependomein inzetbaar zijn (Borghans \& De Grip, 1999, blz. 4). 
In welke mate oud-studenten Rechtsgeleerdheid, achteraf bezien, een meer generiek dan wel meer specialistisch studieprogramma voorstaan, staat weergegeven in figuur 3.1. Uit de figuur komt duidelijk naar voren dat de meerderheid (54\%) van de geënquêteerde oud-studenten Rechtsgeleerdheid tevreden is over de breedte van het curriculum. Bij de andere oud-studenten bestaat een duidelijke voorkeur voor een breed programma (34\%) boven een meer specialistisch curriculum (11\%).

Figuur 3.1

Breed versus specialistisch curriculum gewenst, FdR (\%)
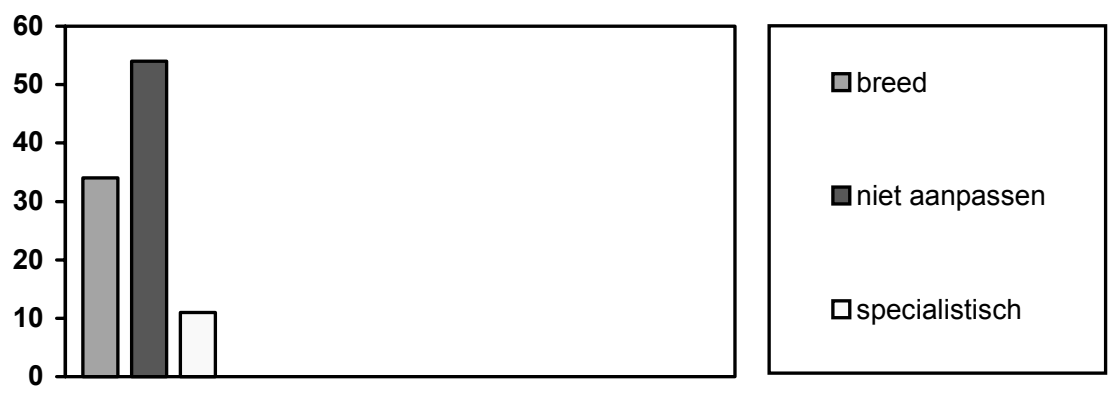

\section{Beroepsgerichtheid}

Figuur 3.2 geeft weer hoeveel van de ondervraagde oud-studenten Rechtsgeleerdheid een meer academisch gericht curriculum dan wel een meer beroepsgericht curriculum willen.

Figuur 3.2

Academisch versus beroepsgericht curriculum gewenst, FdR (\%)
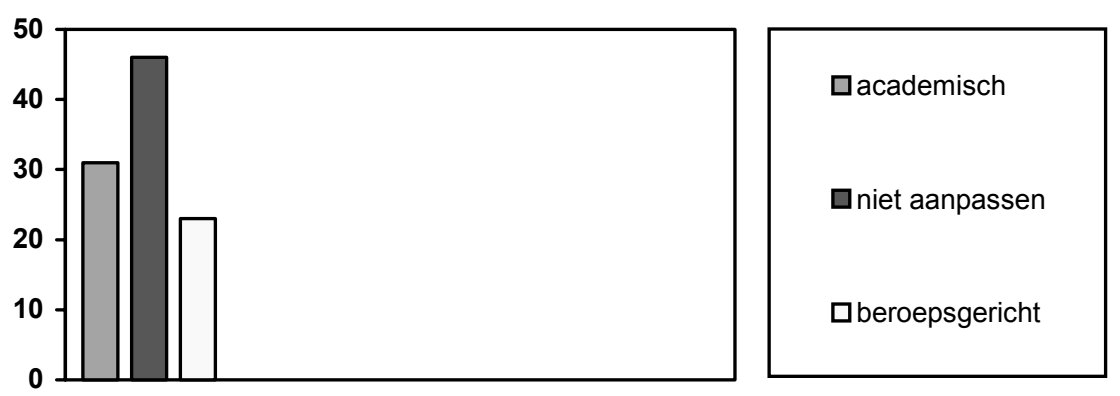

In figuur 3.2 komt naar voren dat de grootste groep oud-studenten (46\%) het curriculum niet zouden aanpassen wat de academische versus beroepsgerichte oriëntatie betreft. Bij de andere oud-studenten bestaat een lichte voorkeur voor een meer academisch gericht curriculum (31\%) boven een meer beroepsgericht curriculum $(23 \%)$. 


\section{Praktijkgerichtheid}

Hoeveel oud-studenten meer praktijkervaring zouden inbouwen in de opleiding, dan wel meer theoretische vakken zouden opnemen in het onderwijsprogramma, wordt weergegeven in figuur 3.3. Deze laat zien dat verreweg de meeste oud-studenten $(69 \%)$ meer praktijkervaring zouden inbouwen in de opleiding, terwijl vrijwel niemand $(9 \%)$ meer theoretische vakken in het curriculum zou opnemen. Bijna een kwart $(23 \%)$ van de respondenten is tevreden over de verhouding tussen gerichtheid op praktijkervaring en theoretische gerichtheid van de opleiding.

Figuur 3.3

Meer praktijkervaring versus meer theoretische vakken, gewenst FdR (\%)

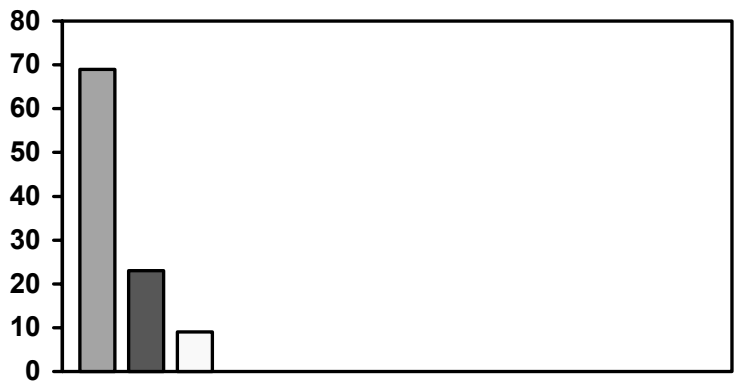

$\square$ meer praktijkervaring

$\square$ niet aanpassen

$\square$ meer theoretische vakken

\section{Oriëntatie op vaardigheden}

Wat de verhouding tussen theorie en vaardigheden betreft, zouden de meeste oudstudenten Rechtsgeleerdheid het curriculum aanpassen door meer nadruk te leggen op vaardigheden (50\%). Een op de acht oud-studenten (12\%) zou meer de nadruk leggen op theorie. Ruim een derde (38\%) van de oud-studenten is tevreden over de verhouding tussen theorie en vaardigheden in de opleiding (figuur 3.4).

Figuur 3.4

Meer theorie versus meer vaardigheden gewenst, FdR (\%)

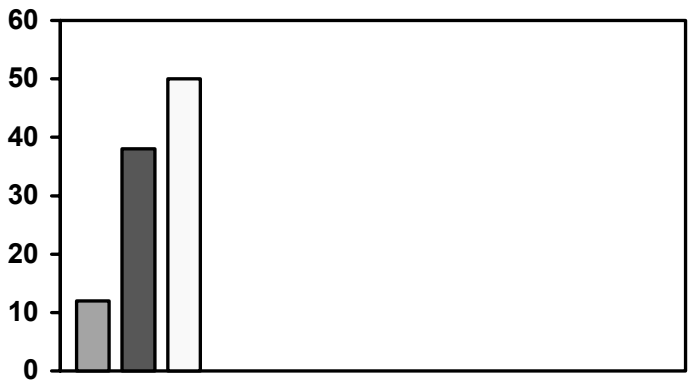

ameer theorie

口niet aanpassen

口meer vaardigheden 


\section{Soort vaardigheden}

Wanneer we kijken naar het soort vaardigheden dat oud-studenten zouden willen benadrukken, dan zien we in figuur 3.5 dat de geënquêteerde oud-studenten vaker de voorkeur geven aan meer beroepsspecifieke vaardigheden (51\%) dan aan meer algemene vaardigheden (34\%). Een kleine minderheid (14\%) zou het curriculum niet aanpassen wat de oriëntatie op algemene dan wel beroepsspecifieke vaardigheden betreft.

\section{Figuur 3.5}

Meer algemene versus meer beroepsspecifieke vaardigheden gewenst, FdR (\%)

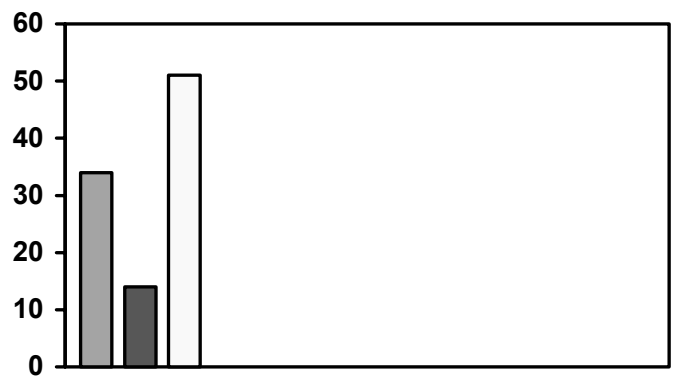

\begin{tabular}{|l|}
\hline \\
vaardigheden \\
valgemene \\
$\square$ niet aanpassen \\
$\square$ meer beroepsspecifieke \\
vaardigheden
\end{tabular}

Vrijheid bij vakkenkeuze

Figuur 3.6 toont de voorkeur van oud-studenten Rechtsgeleerdheid ten aanzien van de vrijheid bij het samenstellen van het vakkenpakket. Over de vrijheid van vakkenkeuze is de overgrote meerderheid (66\%) van de geënquêteerde oudstudenten tevreden. Binnen de minderheid die ontevreden is over de vrijheid van vakkenkeuze, vormen de voorstanders van meer keuzevrijheid $(23 \%)$ een grotere groep dan degenen die vinden dat er minder vrijheid moet zijn in de keuze van vakken (11\%).

\section{Figuur 3.6}

Gewenste vrijheid bij vakkenkeuze, FdR (\%)

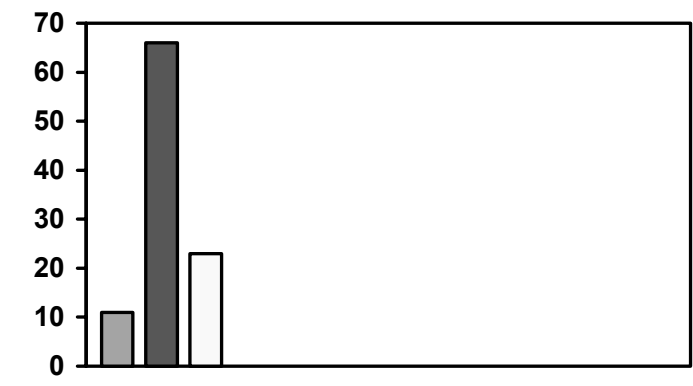

$\square$ minder vrijheid

口niet aanpassen

$\square$ meer vrijheid 


\section{Moeilijkheidsgraad}

Vooral ten gevolge van de verdergaande stijging van de opleidingseisen binnen veel beroepsgroepen is de vraag naar hoger opgeleiden de afgelopen jaren sterk toegenomen. Uit internationaal onderzoek blijkt dat met name de toenemende internationalisering en de daaraan gerelateerde organisatorische veranderingen een belangrijke oorzaak vormen van de toegenomen kwalificatievereisten. De snelle technologische ontwikkelingen leiden tot een toenemende complexiteit van veel functies. Daarnaast bewerkstelligen technologische ontwikkelingen vaak ook organisatorische veranderingen, zoals het schrappen van managementlagen, decentralisering, 'empowerment', e.d. die op hun beurt de kwalificatie-eisen verder doen stijgen. Een belangrijke rol speelt daarbij dat massaproductie in alle sectoren plaats maakt voor op de consument afgestemd maatwerk en een toenemend belang van de kwaliteit van de geleverde goederen en diensten. Het laatste resulteert in de toegenomen aandacht voor kwaliteitszorg, die doorgaans leidt tot meer aandacht voor het belang van goed geschoold personeel (ROA, 1999, blz. 6).

De toenemende kwalificatie-eisen verklaren wellicht waarom niemand van de geënquêteerde oud-studenten Rechtsgeleerdheid een minder zwaar studieprogramma voorstaat. In tegendeel, ruim een derde (37\%) van de oud-studenten is van mening dat het curriculum best zwaarder mag zijn (figuur 3.7). De meerderheid $(63 \%)$ van de oud-studenten is echter tevreden over de zwaarte van het studieprogramma en wil deze dan ook niet aanpassen.

Figuur 3.7

Gewenste zwaarte van het studieprogramma, FdR (\%)
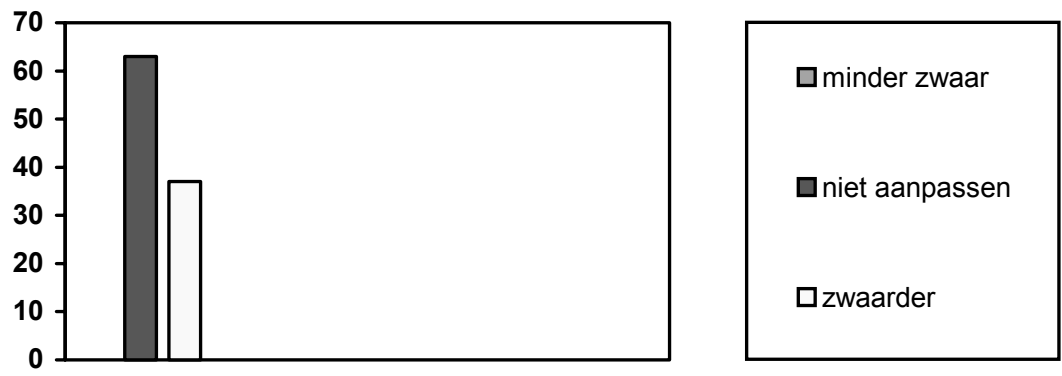

Bij de bevinding dat ruim een derde een zwaarder programma voorstaat, dient te worden opgemerkt dat dit de mening van afgestudeerden betreft, dus van degenen die de opleiding aan de UM destijds met diploma hebben voltooid. Oud-studenten die destijds hun opleiding voortijdig hebben verlaten zullen wellicht een andere mening zijn toegedaan.

\section{Buitenlandoriëntatie}

In het licht van de toenemende internationalisering van onze samenleving bieden universiteiten aan studenten steeds vaker de mogelijkheid om een deel van de 
studie, een stage of een project in het buitenland te volgen. Buitenlandervaring, opgedaan tijdens de opleiding, kan van belang zijn voor de wijze waarop de transitie van studie naar werk en de verdere ontwikkeling van de beroepscarrière verloopt. Zo blijkt uit onderzoek onder universitaire afgestudeerden dat oud-studenten die tijdens hun opleiding buitenlandervaring hebben opgedaan veel vaker op zoek gaan naar werk in het buitenland en ook vaker daadwerkelijk in het buitenland gaan werken dan oud-studenten zonder buitenlandervaring (Meng \& Ramaekers, 2000). Uit het onderzoek van Meng en Ramaekers onder universitaire afgestudeerden blijkt verder dat buitenlandervaring tijdens de opleiding bij afgestudeerden van economische en technische opleidingen tot een verhoging van hun productieve waarde leidt.

Figuur 3.8

Gewenste buitenlandervaring in de opleiding, FdR (\%)
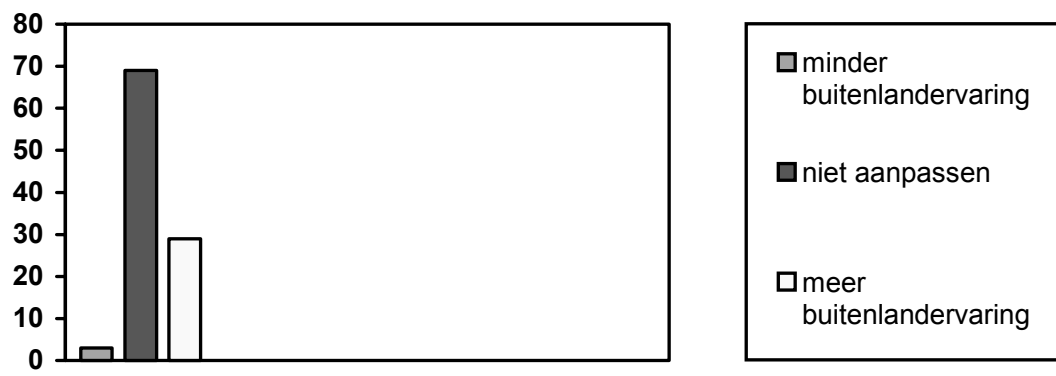

Wat de gewenste aanpassingen van de opleiding betreft, is ten slotte gevraagd naar de mate waarin naar de mening van de oud-studenten buitenlandervaring moet worden ingebouwd in het opleidingsprogramma (figuur 3.8). De overgrote meerderheid $(69 \%)$ van de geënquêteerde oud-studenten Rechtsgeleerdheid is tevreden over de mate waarin de opleiding voorziet in het opdoen van buitenlandervaring. Ruim een kwart (29\%) van de respondenten wenst meer buitenlandervaring in de opleiding, terwijl vrijwel niemand (3\%) de buitenlandervaring wil reduceren.

\subsection{Oordeel over voorbereiding op beroepspraktijk}

Oordeel over startbekwaamheid en potentieel voor verdere ontwikkeling

Aan de oud-studenten is gevraagd om op een vijfpuntschaal (van 'zeer oneens' $\mathrm{t} / \mathrm{m}$ 'zeer eens') aan te geven in welke mate zij het eens zijn met de stelling dat de opleiding hen startbekwaam heeft gemaakt voor de arbeidsmarkt en een basis heeft verschaft om zich beroepsmatig verder te ontwikkelen. Tabel 3.7 toont het procentuele aandeel van de oud-studenten, die de stelling onderschrijven dat de opleiding een goede basis biedt (antwoordcategorie 4 of 5 ) om te starten op de arbeidsmarkt respectievelijk kennis en vaardigheden verder te ontwikkelen.

Hoewel iets meer dan de helft van de oud-studenten Rechtsgeleerdheid vindt dat de opleiding hen voldoende heeft toegerust om adequaat te kunnen starten in de beroepspraktijk, is ook bijna de helft van de geënquêteerde oud-studenten - achteraf 
terugblikkend - van mening dat hun startbekwaamheid onvoldoende was. Dit hoeft overigens niet problematisch te zijn geweest voor hun verdere beroepsmatige ontwikkeling. Immers, vrijwel alle geënquêteerde oud-studenten vinden - achteraf terugblikkend - dat de opleiding een voldoende basis heeft geboden om kennis en vaardigheden verder te kunnen ontwikkelen, bijvoorbeeld via nascholing.

Tabel 3.7

Oordeel over de voorbereiding op de beroepspraktijk, FdR: \% (zeer) met stelling eens*

- $\quad$ De kennis en vaardigheden die ik tijdens de opleiding heb verworven, zijn voldoende om adequaat te starten in de beroepspraktijk

De opleiding biedt voldoende basis voor het verder ontwikkelen van kennis en vaardigheden

* Percentage oud-studenten dat 4 of 5 scoort op een schaal van 1 (zeer oneens) t/m 5 (zeer eens).

In tabel 3.8 wordt de startbekwaamheid nader gespecificeerd door na te gaan in hoeverre oud-studenten Rechtsgeleerdheid bij de overgang naar de beroepspraktijk tekorten in theoretische kennis, praktische vaardigheden en omgang met praktijkproblemen/-situaties hebben ervaren. Vervolgens wordt in tabel 3.9 nagegaan of nascholing nodig was vanwege tekortkomingen in de opleiding.

Bij de start op de arbeidsmarkt ervaren opleidingstekorten

Aan de oud-studenten zijn drie stellingen voorgelegd, die verwijzen naar eventuele tekorten in theoretische kennis, praktische vaardigheden en praktijkervaring die zij bij de overgang naar de beroepspraktijk hebben ervaren. Tabel 3.8 toont hoeveel procent van de oud-studenten het met de drie stellingen eens is (antwoordcategorie 4 of 5 , gemeten op een vijfpuntschaal van: 'zeer oneens' $t / m$ 'zeer eens').

Tabel 3.8

Ervaren tekorten bij de overgang naar de beroepspraktijk, FdR: \% (zeer) met stelling eens*

- Bij de overgang naar de beroepspraktijk heb ik tekorten ervaren in theoretische kennis

- $\quad$ Bij de overgang naar de beroepspraktijk heb ik tekorten ervaren in praktische vaardigheden

- $\quad$ Tijdens mijn opleiding ben ik voldoende in aanraking geweest met praktijkproblemen en praktijksituaties

* Percentage oud-studenten dat 4 of 5 scoort op een schaal van 1 (zeer oneens) t/m 5 (zeer eens).

Uit tabel 3.7 is naar voren gekomen dat bijna de helft van de oud-studenten vindt dat de opleiding hen onvoldoende heeft toegerust om adequaat te kunnen starten in de beroepspraktijk. Uit tabel 3.8 blijkt dat het hierbij vooral gaat om tekorten in praktische vaardigheden en omgang met praktijkproblemen/-situaties, en niet om tekorten in theoretische kennis. 


\section{Belang van nascholing}

$\mathrm{Na}$ het afstuderen houdt het verwerven van kennis en vaardigheden niet op. Mede gezien de veranderingen in de arbeidsmarkt en de daaruit voortkomende veranderingen in de gewenste competenties, mag worden verwacht dat er behoefte blijft bestaan aan bijscholing. Tegen deze achtergrond zijn drie stellingen, die betrekking hebben op de noodzaak van nascholing, voorgelegd aan de oudstudenten. Tabel 3.9 toont hoeveel procent van de oud-studenten het met de drie stellingen eens is (antwoordcategorie 4 of 5 , gemeten op een vijfpuntschaal van: 'zeer oneens' $\mathrm{t} / \mathrm{m}$ 'zeer eens').

Tabel 3.9

Oordeel over de relevantie van nascholing, FdR: \% (zeer) met stelling eens*

- $\quad$ Nascholing is nodig vanwege tekortkomingen in mijn opleiding

Nascholing is nodig om kennis en vaardigheden op te doen die beter te leren zijn in combinatie met werk

- $\quad$ Nascholing is nodig vanwege nieuwe ontwikkelingen die niet te voorzien waren tijdens mijn opleiding

* Percentage oud-studenten dat 4 of 5 scoort op een schaal van 1 (zeer oneens) t/m 5 (zeer eens).

Hoewel bijna de helft van de geënquêteerde oud-studenten Rechtsgeleerdheid vindt dat de opleiding hen onvoldoende heeft toegerust om adequaat te kunnen starten in de beroepspraktijk (tabel 3.7), onderschrijft 'slechts' een op de tien oud-studenten de stelling dat nascholing nodig is vanwege tekortkomingen in de opleiding. Blijkbaar wordt onvoldoende startbekwaamheid doorgaans niet beschouwd als een tekortkoming van de opleiding. Het lijkt er eerder op dat oud-studenten de opleiding eerder 'afrekenen' op hun vermogen om kennis en vaardigheden verder te ontwikkelen dan op hun startbekwaamheid. Immers, in tabel 3.7 hebben we kunnen zien dat vrijwel alle oud-studenten van mening zijn dat de opleiding een voldoende basis heeft geboden om kennis en vaardigheden verder te kúnnen ontwikkelen, bijvoorbeeld via scholing. Het gaat dan om kennis en vaardigheden die beter te leren zijn in combinatie met werk of om nieuwe ontwikkelingen die niet te voorzien zijn tijdens de opleiding (tabel 3.9). Uit onderzoek van het ROA is gebleken dat bijvoorbeeld managementvaardigheden beter te leren zijn in combinatie met werk dan in het initiële onderwijs (Heijke, Meng \& Ramaekers, 2003, Heijke, Ramaekers \& Ris, 2004).

\subsection{Conclusies en aanbevelingen}

Aan het onderzoek hebben 58 oud-studenten Rechtsgeleerdheid deelgenomen, wat neerkomt op een respons van $22 \%$. De analyse is echter beperkt tot 35 oudstudenten Rechtsgeleerdheid, namelijk degenen die werkzaam zijn in functies waarvoor de opleiding beoogde op te leiden.

Discrepanties tussen het niveau van competenties dat vereist is in de functie en het 'eigen' competentieniveau van oud-studenten Rechtsgeleerdheid zijn doorgaans zeer gering. Bij de opleidingspecifieke competenties manifesteren zich zelfs nauwelijks of 
geen discrepanties. Kortom, het competentieniveau van de oud-studenten is door de bank genomen toereikend voor het niveau dat vereist is in hun functie. Dit geldt ook voor het vermogen om presentaties te geven, waarvan de geënquêteerde oud-studenten echter aangeven dat dit te weinig aan bod is gekomen in de opleiding.

Over de wijze waarop de opleiding hen heeft voorbereid op de beroepspraktijk zijn zeven van de tien oud-studenten Rechtsgeleerdheid tevreden. Vooral over de nadruk die in de opleiding wordt gelegd op onderwijsgroepen is een overduidelijke meerderheid van de geënquêteerde oud-studenten Rechtsgeleerdheid tevreden. Echter, op vaardigheidstrainingen, presenteren en practica zou volgens een ruime meerderheid méér nadruk gelegd moeten worden.

Als voorbereiding op de beroepspraktijk wordt de stage positiever beoordeeld dan de scriptie. Slechts een op de vijf oud-studenten Rechtsgeleerdheid vindt dat zij aan de vaardigheden, opgedaan tijdens het schrijven van de scriptie voldoende hebben geleerd voor de beroepspraktijk. De helft slechts is van mening dat de scriptie een duidelijke meerwaarde aan de opleiding heeft gegeven. De stage daarentegen wordt door bijna alle oud-studenten Rechtsgeleerdheid als meerwaarde voor de opleiding gezien. De meeste oud-studenten vinden dat zij in de stage voldoende hebben geleerd voor de praktijk. Deze positieve beoordeling van het nut van stages verklaart wellicht waarom iets meer dan de helft van de geënquêteerde oud-studenten vindt dat er meer mogelijkheden zouden moeten zijn om stage te kunnen lopen.

Van de geënquêteerde oud-studenten is de grootste groep tevreden over de breedte van het curriculum, de academische versus beroepsgerichte oriëntatie van het curriculum, de vrijheid van vakkenkeuze, de zwaarte van de opleiding en de mate waarin de opleiding voorziet in het opdoen van buitenlandervaring. Er zijn echter wel een paar punten die de geënquêteerde oud-studenten zouden willen aanpassen in de oriëntatie van het curriculum. Ten eerste, zouden verreweg de meeste respondenten meer praktijkervaring in plaats van meer theoretische vakken in het curriculum inbouwen. Een tweede punt van aandacht is de voorkeur van oud-studenten voor meer vaardigheden in plaats van meer theorie in de opleiding. Wat het gewenste soort vaardigheden betreft, hebben de oud-studenten een voorkeur voor het benadrukken van meer beroepsspecifieke vaardigheden in plaats van meer algemene vaardigheden.

Bijna de helft van de onderzochte oud-studenten Rechtsgeleerdheid vindt dat de opleiding hen onvoldoende heeft toegerust om adequaat te kunnen starten in de beroepspraktijk. Het gaat hierbij vooral om tekorten in praktische vaardigheden en omgang met praktijkproblemen/-situaties, en niet om tekorten in theoretische kennis. Dit hoeft overigens niet problematisch te zijn voor hun verdere beroepsmatige ontwikkeling. Immers, vrijwel alle respondenten vinden dat de opleiding een goede basis heeft gelegd om kennis en vaardigheden verder te kunnen ontwikkelen. Het is dan ook niet verwonderlijk dat de overgrote meerderheid niet vindt dat nascholing nodig is vanwege tekortkomingen in de opleiding, maar vanwege nieuwe ontwikkelingen die niet te voorzien zijn tijdens de opleiding, of om kennis en vaardigheden op te doen die beter te leren zijn in combinatie met werk. 
Kort samengevat luiden de aanbevelingen ${ }^{3}$ van de geënquêteerde oud-studenten Rechtsgeleerdheid voor aanpassingen in het curriculum:

- Liever meer praktijkervaring inbouwen in de opleiding dan meer theoretische vakken opnemen in het curriculum;

- Liever streven naar meer vaardigheden dan naar meer theorie;

- Liever meer nadruk op beroepsspecifieke vaardigheden dan op meer algemene vaardigheden;

- In de opleiding een zwaarder accent leggen op vaardigheidstrainingen, practica en het geven van presentaties/voordrachten. ;

- Meer stagemogelijkheden bieden.

3. De hier gepresenteerde aanbevelingen zijn niet geordend naar belangrijkheid. 


\section{Resultaten Faculteit der Economische Wetenschappen en Bedrijfskunde}

In dit hoofdstuk worden de resultaten besproken van het eind 2003 uitgevoerde curriculumonderzoek onder oud-studenten van afstudeerjaargang 1996/1997. De resultaten hebben dus betrekking op oud-studenten die op het moment van de enquête zo'n zes jaar op de arbeidsmarkt vertoeven. Op de enquête hebben in totaal 63 oud-studenten van de FdEWB gerespondeerd (respons 21\%). De analyse is echter beperkt tot de 49 oud-studenten van de FdEWB die werkzaam zijn in functies op tenminste hbo niveau, waarvoor de eigen of een verwante opleidingsrichting is vereist. Dit is gedaan om te voorkomen dat de opleiding mede wordt 'afgerekend' op het oordeel van oud-studenten, die werkzaam zijn in functies waarvoor de opleiding niet beoogde op te leiden.

In de enquête is aan de oud-studenten gevraagd om een aantal aspecten van hun opleiding te evalueren. Deze aspecten betreffen achtereenvolgens de competenties waarover oud-studenten (dienen te) beschikken en de aandacht die de opleiding hieraan zou moeten besteden (paragraaf 4.1), de nadruk die oud-studenten zouden leggen op verschillende didactische werkvormen (paragraaf 4.2), het nut dat oudstudenten toekennen aan de studieonderdelen scriptie en stage (paragraaf 4.3), de accenten die oud-studenten zouden leggen in de gerichtheid van het curriculum op een aantal aspecten (paragraaf 4.4), hun oordeel over de mate waarin de opleiding hen heeft voorbereid op de beroepspraktijk en het belang van nascholing hierbij (paragraaf 4.5). Tot slot worden in paragraaf 4.6 de belangrijkste bevindingen samengevat in de vorm van een aantal conclusies en aanbevelingen.

\subsection{Competenties}

Waarom meting van competenties?

Er zijn verschillende redenen om onderzoek naar competenties van hoger opgeleiden verder te ontwikkelen. In de eerste plaats kunnen gegevens over competenties worden gebruikt voor het bewaken en verbeteren van de kwaliteit van opleidingen in termen van de mate waarin zij afgestudeerden hebben voorbereid op de beroepspraktijk. Dezelfde gegevens kunnen ook worden gebruikt om effecten van veranderingen in het hoger onderwijs te evalueren, zoals de invoering van het bama-stelsel. Tot slot kunnen gegevens over competenties helpen om meer inzicht te krijgen in hoe de arbeidsmarkt werkt. Hieronder wordt nader ingegaan op deze drie redenen om competenties te meten.

Tegen de achtergrond van de invoering van een systeem van accreditering in het kader van de kwaliteitszorg van het hoger onderwijs, is de laatste jaren een verschuiving waar te nemen in de informatiebehoefte van degenen die zich bezig houden met diverse aspecten van de kwaliteit van het hoger onderwijs. Werd in het verleden meer naar de inputfactoren en het onderwijsproces zelf gekeken, thans 
wordt meer het accent gelegd op de eindtermen en de gewenste output van opleidingen. Hierbinnen is ook een verschuiving opgetreden, van de onderwijsprestaties zelf (geïndiceerd door bijvoorbeeld eindexamenresultaten) naar de competenties waarover afgestudeerden (dienen te) beschikken. De redenering hierbij is simpel: "the proof of the pudding is in the eating", en opleidingen kunnen het beste hun kwaliteit aantonen middels de geschiktheid van de afgestudeerden om in de praktijk te functioneren.

Een tweede reden om zicht te krijgen op de competenties van afgestudeerden betreft de invoering van de bachelor-master structuur. Deze raakt de verhouding in oriëntatie tussen het hoger beroepsonderwijs en het wetenschappelijk onderwijs, en de differentiatie in twee uitstroomniveaus. Het meten van competenties is in dit kader van belang voor het ontwikkelen van een transparante kwalificatiestructuur van het hoger onderwijs en voor de organiseerbaarheid van het hoger onderwijs.

Naast bovengenoemde institutionele redenen is meting van competenties uit wetenschappelijk oogpunt relevant, omdat hiermee een beter inzicht in de werking van de arbeidsmarkt kan worden verkregen. Over de betekenis van onderwijs voor het latere beroepsmatig functioneren bestaan verschillende theorieën. Deze verschillen enerzijds met betrekking tot de vraag in hoeverre competenties in het onderwijs worden opgedaan (en zo ja welke competenties), en anderzijds met betrekking tot de vraag welke rol competenties spelen bij selectie, allocatie en beloning van werkenden. Een tweede punt van discussie betreft de vraag wat voor soort competenties op de arbeidsmarkt worden gevraagd. Wat is het relatieve belang van specifieke competenties ten opzichte van de meer generieke competenties? Worden in de transitiefase van school naar werk andere competenties gevraagd dan in latere fasen van de loopbaan? Welke competenties hebben oud-studenten nodig om snel productief inzetbaar te zijn (startbekwaam) en welke competenties verzekeren hun employability op langere termijn? Wat betekent dit voor het curriculum? Deze vragen zijn van wezenlijk belang, niet alleen vanuit theoretische optiek maar ook om te komen tot een meer effectieve en efficiënte inrichting van het onderwijs.

Tegen de bovengeschetste achtergrond is aan alle oud-studenten een lijst voorgelegd van 31 generieke competenties die in het werk van belang kunnen zijn. Deze lijst van generieke competenties is voor oud-studenten Economie uitgebreid met 5 opleidingspecifieke competenties.

Aan de oud-studenten is gevraagd om voor iedere competentie een inschatting te geven van achtereenvolgens:

- $\quad$ het niveau dat vereist is in hun huidige functie;

- $\quad$ hun eigen niveau;

- $\quad$ waar zij de competentie vooral hebben geleerd.

Zowel het vereiste als het eigen niveau konden zij aangeven op een vijfpuntschaal (van 'relatief laag' $t / m$ 'relatief hoog'). De belangrijkste leerbron van de competentie konden zij aangeven op een vijfpuntschaal (van 'buiten de WO-opleiding' $\mathrm{t} / \mathrm{m}$ 'in de WO-opleiding'). 


\section{Vereist niveau van competenties}

Kolom 2 van tabel 4.1 toont voor iedere competentie welk percentage van de betaald werkende oud-studenten het in de functie vereiste niveau als hoog inschat (antwoordcategorie 4 of 5).

Tabel 4.1

Vereist en eigen competentieniveau, FdEWB (\% hoog niveau*)

Vereist niveau Eigen niveau

\section{Kennis van}

$\begin{array}{lrl}\text { het eigen vakgebied } & 67 & 84 \\ \text { andere vakgebieden } & 64 & 45 \\ \text { Vermogen om: } & 78 & 82 \\ \text { vakkennis in de praktijk toe te passen } & 96 & 96 \\ \text { informatie te vergaren } & 98 & 94 \\ \text { problemen te analyseren en op te lossen } & 100 & 94 \\ \text { verbanden te leggen tussen verschillende zaken } & 96 & 86 \\ \text { hoofdzaken van bijzaken te onderscheiden } & 90 & 96 \\ \text { logisch te redeneren } & 63 & 67 \\ \text { conform budget en planning te werken } & 86 & 78 \\ \text { onder druk goed te functioneren } & 76 & 67 \\ \text { besluiten te nemen } & 71 & 69 \\ \text { nieuwe ideeën en oplossingen te bedenken } & 74 & 69 \\ \text { continue te leren } & 88 & 69 \\ \text { aan anderen duidelijk te maken wat u bedoelt } & 71 & 80 \\ \text { met anderen samen te werken } & 41 & 42 \\ \text { leiding te geven } & 88 & 98 \\ \text { zelfstandig te werken } & 55 & 50 \\ \text { in conflictsituaties adequaat te reageren } & 58 & 74 \\ \text { presentaties te geven } & 76 & 76 \\ \text { gesprekken te voeren } & 65 & 84 \\ \text { rapporten en brieven te schrijven } & & 78 \\ \text { in buitenlandse talen te communiceren } & 50 & 67 \\ \text { ICT te gebruiken } & 77 & \\ \text { eidheid om: } & & 48 \\ \text { werkgerelateerde risico's te nemen } & & 66 \\ \text { ideeën van uzelf en anderen ter discussie te stellen } & 58 & 68 \\ \text { op te komen voor uw eigen standpunt } & 77 & 72 \\ \text { begrip te tonen voor andere standpunten } & 85 & 81 \\ \text { verantwoordelijkheid te nemen } & 92 & 83 \\ \text { kritisch na te denken over uw eigen handelen } & 87 & 63 \\ \text { uw gedrag aan te passen aan de situatie } & 87 & 66 \\ \text { feedback te ontvangen en te geven } & 70 & 81 \\ \end{array}$

feedback te ontvangen en te geven

Vermogen om (opleidingspecifiek):

vakspecifieke technieken te gebruiken

(boekhoudkundige/statistische software e.d.)

schrijven, organogram maken, financieringsplan

opstellen,organisaties adviseren, onderhandelen met cliënten)

om te gaan met verschillende culturen

bij economische/bedrijfskundige beslissingen, ethische en maatschappelijke aspecten te betrekken

een overzicht te hebben van de belangen van andere afdelingen/belanghebbenden

* Percentage oud-studenten dat 4 of 5 scoort op een schaal van 1 (relatief laag) t/m 5 (relatief hoog). 
Van de opleidingspecifieke competenties moeten oud-studenten Economie het vaakst op een hoog niveau beschikken over het vermogen om vakspecifieke handelingen uit te voeren en een overzicht te hebben van de belangen van andere afdelingen/belanghebbenden. Tenminste driekwart van de geënquêteerde oudstudenten moet hierover op een hoog niveau beschikken. Minder oud-studenten alhoewel nog steeds de helft of meer - moeten op een hoog niveau het vermogen hebben om vakspecifieke technieken te gebruiken en om te gaan met verschillende culturen. Slechts een op de drie oud-studenten Economie moet op een hoog niveau in staat zijn om bij economische/bedrijfskundige beslissingen ethische en maatschappelijke aspecten te betrekken.

Kijken we naar de generieke competenties, dan moeten tenminste negen van de tien oud-studenten Economie op een hoog niveau beschikken over:

- $\quad$ het vermogen om informatie te vergaren;

- $\quad$ het vermogen om logisch te redeneren;

- analytische competenties (vermogen om problemen te analyseren en op te lossen, verbanden te leggen tussen verschillende zaken en hoofdzaken van bijzaken te onderscheiden);

- $\quad$ de bereidheid om begrip te tonen voor andere standpunten.

\section{Eigen niveau van de competenties}

Kolom 3 van tabel 4.1 toont voor iedere competentie welk percentage van de oudstudenten het eigen niveau als hoog inschat (antwoordcategorie 4 of 5).

Van de opleidingspecifieke competenties schatten oud-studenten Economie hun vermogen om vakspecifieke handelingen uit te voeren en een overzicht te hebben van de belangen van andere afdelingen/belanghebbenden het vaakst als hoog in. Tenminste driekwart van de geënquêteerde oud-studenten vindt dat zij deze competenties op een hoog niveau beheersen. Het minst vaak, maar nog altijd de helft van de oud-studenten, schatten zij hun vermogen om bij economische/ bedrijfskundige beslissingen ethische en maatschappelijke aspecten te betrekken als hoog in.

Met betrekking tot de generieke competenties, schat minder dan de helft van de geënquêteerde oud-studenten hun kennis van andere vakgebieden, hun vermogen om leiding te geven, en hun bereidheid om werkgerelateerde risico's te nemen als hoog in.

\section{Discrepanties tussen vereist niveau en eigen niveau van competenties}

De discrepantie tussen het vereiste niveau en het aanwezige niveau van competenties geeft per competentieaspect een indicatie voor eventuele tekorten of overschotten, en kan daarmee licht werpen op de vraag in hoeverre opleidingen van de UM de kwaliteit leveren die op de arbeidsmarkt van hen wordt verlangd. 
Vergelijking van het vereiste competentieniveau met het 'eigen' competentieniveau (tabel 4.1) toont dat bij vijf competenties het procentuele aandeel van oud-studenten die hun eigen niveau als hoog inschatten tenminste 15\%-punt lager ligt dan het procentuele aandeel van oud-studenten die het vereiste niveau als hoog inschatten. Bij deze 'tekortschietende' competenties van oud-studenten gaat het om kennis van andere vakgebieden, het vermogen om aan anderen duidelijk te maken wat men bedoelt alsmede de bereidheid om op te komen voor het eigen standpunt, begrip te tonen voor andere standpunten en feedback te ontvangen/geven. Deze betreffen allen generieke competenties. Ten aanzien van de opleidingspecifieke competenties manifesteren zich nauwelijks of geen tekorten bij oud-studenten. In tegendeel, bij drie opleidingspecifieke competenties - namelijk kennis van het eigen vakgebied, het kunnen omgaan met verschillende culturen en het vermogen om bij economische/ bedrijfskundige beslissingen ethische en maatschappelijke aspecten te betrekken ligt het niveau van de oud-studenten duidelijk hoger dan het niveau dat vereist is in hun functie. Ook bij het (communicatieve) vermogen om presentaties te geven, rapporten en brieven te schrijven en in buitenlandse talen te communiceren, ligt het niveau van de oud-studenten duidelijk hoger dan het niveau dat vereist is in hun functie.

In het licht van de geconstateerde verschillen tussen het vereiste niveau en het eigen niveau wordt in tabel 4.3 nagegaan in hoeverre de aandacht die de opleiding aan competenties besteedt volgens de oud-studenten zou moeten worden bijgesteld. Echter, aangezien competenties slechts ten dele binnen het initieel onderwijs worden opgedaan, wordt eerst in tabel 4.2 nagegaan in welke mate oud-studenten de competenties vooral in de initiële WO-opleiding hebben opgedaan.

\section{Belangrijkste leerbron van competenties}

Competenties worden niet alleen tijdens het volgen van een initiële opleiding opgedaan maar ook na het afstuderen, bijvoorbeeld in postdoctorale beroepsopleidingen en cursussen of tijdens de uitoefening van een beroep. Aan de oudstudenten is gevraagd om voor iedere competentie aan te geven waar zij de betreffende competentie vooral hebben geleerd. Zij konden dit aangeven op een vijfpuntschaal (van 1 'buiten de WO-opleiding' t/m 5 'in de WO-opleiding'). Tabel 4.2 toont voor iedere competentie welk percentage van de oud-studenten aangeeft dat de betreffende competentie vooral in de WO-opleiding is opgedaan (antwoordcategorie 4 of 5 ).

De tabel laat zien dat de meeste competenties voornamelijk buiten of na de opleiding worden opgedaan. Slechts één opleidingspecifieke competentie en drie generieke competenties zijn door meer dan de helft van de oud-studenten vooral in de initiële opleiding opgedaan, namelijk kennis van het eigen vakgebied, het vermogen om problemen te analyseren en op te lossen, logisch te redeneren en met anderen samen te werken. Deze competenties moeten overigens door tenminste tweederde van de oud-studenten op een hoog niveau worden beheerst (tabel 4.1). 
Generieke competenties die vrijwel uitsluitend (door meer dan 90\% van de oudstudenten) buiten of na de opleiding worden opgedaan, zijn het vermogen om onder druk goed te functioneren, besluiten te nemen, leiding te geven, in conflictsituaties adequaat te reageren, en de bereidheid om werkgerelateerde risico's te nemen.

Tabel 4.2

Belangrijkste leerbron van competenties, FdEWB (\% in de WO-opleiding*)

Kennis van:

- $\quad$ het eigen vakgebied 63

andere vakgebieden 13

Vermogen om:

vakkennis in de praktijk toe te passen 33

informatie te vergaren $\quad 50$

problemen te analyseren en op te lossen $\quad 75$

verbanden te leggen tussen verschillende zaken $\quad 50$

hoofdzaken van bijzaken te onderscheiden 44

logisch te redeneren 58

$\begin{array}{lr}\text { conform budget en planning te werken } & 13\end{array}$

onder druk goed te functioneren

besluiten te nemen 6

nieuwe ideeën en oplossingen te bedenken $\quad 21$

continue te leren 46

aan anderen duidelijk te maken wat u bedoelt 33

met anderen samen te werken $\quad 56$

leiding te geven 2

zelfstandig te werken 46

$\begin{array}{lr}\text { in conflictsituaties adequaat te reageren } & 87 \\ \text { presentaties te geven } & 67\end{array}$

$\begin{array}{ll}\text { gesprekken te voeren } & 27\end{array}$

$\begin{array}{ll}\text { rapporten en brieven te schrijven } & 48\end{array}$

in buitenlandse talen te communiceren 48

ICT te gebruiken 23

Bereidheid om:

- werkgerelateerde risico's te nemen 6

ideeën van uzelf en anderen ter discussie te stellen 49

op te komen voor uw eigen standpunt 38

begrip te tonen voor andere standpunten 32

$\begin{array}{ll}\text { verantwoordelijkheid te nemen } & 19\end{array}$

kritisch na te denken over uw eigen handelen 34

$\begin{array}{ll}\text { uw gedrag aan te passen aan de situatie } & 17\end{array}$

feedback te ontvangen en te geven 38

Vermogen om (opleidingspecifiek):

$\begin{array}{ll}\text { - } & \text { vakspecifieke technieken te gebruiken (boekhoudkundige/statistische } \\ \quad \text { software e.d.) } & 39\end{array}$

- $\quad$ vakspecifieke handelingen uit te voeren (marketing plan schrijven,

organogram maken, financieringsplan opstellen,organisaties adviseren, onderhandelen met cliënten)

om te gaan met verschillende culturen 30

- $\quad$ bij economische/bedrijfskundige beslissingen, ethische en

maatschappelijke aspecten te betrekken

van andere afdelingen/belanghebbenden * Percentage oud-studenten dat 4 of 5 scoort op een schaal van 1 (buiten de WO-opleiding)
t/m 5 (in de WO-opleiding). 
Tabel 4.3

Oordeel over de mate waarin competenties aan bod komen tijdens de opleiding, FdEWB (\%)

\begin{tabular}{|c|c|c|c|}
\hline & $\begin{array}{l}\text { Te veel } \\
\text { aan bod }\end{array}$ & $\begin{array}{l}\text { Te weinig } \\
\text { aan bod }\end{array}$ & $\begin{array}{l}\text { Saldo(te veel } \\
\text { - te weinig) }\end{array}$ \\
\hline \multicolumn{4}{|l|}{ Kennis van: } \\
\hline - $\quad$ het eigen vakgebied & 12 & 3 & 9 \\
\hline - $\quad$ andere vakgebieden & 0 & 3 & -3 \\
\hline \multicolumn{4}{|l|}{ Vermogen om: } \\
\hline - vakkennis in de praktijk toe te passen & 0 & 22 & -22 \\
\hline - informatie te vergaren & 29 & 3 & 26 \\
\hline - $\quad$ problemen te analyseren en op te lossen & 18 & 0 & 18 \\
\hline - verbanden te leggen tussen verschillende zaken & 0 & 0 & 0 \\
\hline - $\quad$ hoofdzaken van bijzaken te onderscheiden & 0 & 8 & -8 \\
\hline - $\quad$ logisch te redeneren & 0 & 0 & 0 \\
\hline - $\quad$ conform budget en planning te werken & 0 & 25 & -25 \\
\hline onder druk goed te functioneren & 0 & 19 & -19 \\
\hline besluiten te nemen & 0 & 22 & -22 \\
\hline nieuwe ideeën en oplossingen te bedenken & 0 & 6 & -6 \\
\hline continue te leren & 0 & 0 & 0 \\
\hline - $\quad$ aan anderen duidelijk te maken wat $u$ bedoelt & 6 & 0 & 6 \\
\hline met anderen samen te werken & 18 & 0 & 18 \\
\hline leiding te geven & 6 & 28 & -22 \\
\hline zelfstandig te werken & 6 & 0 & 6 \\
\hline in conflictsituaties adequaat te reageren & 0 & 31 & -31 \\
\hline presentaties te geven & 24 & 3 & 21 \\
\hline gesprekken te voeren & 0 & 6 & -6 \\
\hline rapporten en brieven te schrijven & 12 & 3 & 9 \\
\hline in buitenlandse talen te communiceren & 0 & 8 & -8 \\
\hline - ICT te gebruiken & 0 & 14 & -14 \\
\hline \multicolumn{4}{|l|}{ Bereidheid om: } \\
\hline \multirow{2}{*}{$\begin{array}{ll}\text { - } & \text { werkgerelateerde risico's te nemen } \\
\text { - } & \text { ideeën van uzelf en anderen ter discussie te } \\
\text { stellen }\end{array}$} & 0 & 8 & -8 \\
\hline & 24 & 6 & 18 \\
\hline - $\quad$ op te komen voor uw eigen standpunt & $\begin{array}{r}24 \\
0\end{array}$ & 0 & $\begin{array}{r}10 \\
0\end{array}$ \\
\hline begrip te tonen voor andere standpunten & 0 & 3 & -3 \\
\hline - verantwoordelijkheid te nemen & 0 & 0 & 0 \\
\hline - $\quad$ kritisch na te denken over uw eigen handelen & 0 & 6 & -6 \\
\hline - uw gedrag aan te passen aan de situatie & 0 & 0 & 0 \\
\hline - $\quad$ feedback te ontvangen en te geven & 12 & 6 & 6 \\
\hline \multicolumn{4}{|l|}{$\begin{array}{l}\text { Vermogen om (opleidingspecifiek): } \\
-\quad \text { vakspecifieke technieken te gebruiken }\end{array}$} \\
\hline \multirow{5}{*}{$\begin{array}{l}\text { (boekhoudkundige/statistische software e.d.) } \\
\text { vakspecifieke handelingen uit te voeren } \\
\text { (marketing plan schrijven, organogram maken, } \\
\text { financieringsplan opstellen,organisaties adviseren, } \\
\text { onderhandelen met cliënten) } \\
\text { om te gaan met verschillende culturen } \\
\text { bij economische/bedrijfskundige beslissingen, } \\
\text { ethische en maatschappelijke aspecten te } \\
\text { betrekken } \\
\text { een overzicht te hebben van de belangen van } \\
\text { andere afdelingen/belanghebbenden }\end{array}$} & 12 & 14 & -2 \\
\hline & 6 & 6 & 0 \\
\hline & 0 & 0 & 0 \\
\hline & 0 & 6 & -6 \\
\hline & 0 & 6 & -6 \\
\hline
\end{tabular}

\section{Mening over bestede aandacht aan competenties}

In tabel 4.3 wordt nagegaan of de generieke en opleidingspecifieke competenties volgens de oud-studenten wel voldoende aan bod zijn gekomen tijdens hun WOopleiding. Daartoe is aan de oud-studenten gevraagd om van de generieke en 
opleidingspecifieke competenties er maximaal 3 te noemen waarvan zij vonden dat deze in hun WO-opleiding te weinig aan bod zijn gekomen, en die dus volgens hen meer aandacht hadden moeten krijgen. Aangezien meer aandacht voor de ene competentie, bij een gelijkblijvende studieduur, minder aandacht voor een andere competentie betekent, is aan de oud-studenten ook gevraagd om maximaal 3 competenties te noemen die naar hun mening te veel aan bod zijn gekomen. Tabel 4.3 toont de scores van oud-studenten Economie op beide vragen.

Als eerste valt op dat oud-studenten Economie slechts bij twee competenties duidelijk verdeeld zijn in hun mening over de mate waarin deze in hun opleiding aan bod zijn gekomen. Zo noemt $12 \%$ het vermogen om vakspecifieke technieken te gebruiken als één van de drie competenties die te veel aan bod zijn gekomen tijdens de opleiding Economie, terwijl een nagenoeg gelijk percentage (namelijk 14\%) deze competentie noemt als één van de drie die te weinig aan bod zijn gekomen. Dezelfde verdeeldheid zien we bij het vermogen om vakspecifieke handelingen uit te voeren.

Vier competenties zijn door tenminste $20 \%$ van de oud-studenten genoemd als één van de drie competenties die te weinig aan bod zijn gekomen tijdens de opleiding Economie, terwijl niemand deze competenties heeft genoemd als één van de drie competenties die te veel aan bod zijn gekomen. Deze te weinig aan bod gekomen competenties betreffen het vermogen om vakkennis in de praktijk toe te passen, conform budget en planning te werken, besluiten te nemen en in conflictsituaties adequaat te reageren. Ook wat het vermogen om leiding te geven betreft, schiet de opleiding volgens veel oud-studenten tekort. Wellicht omdat deze competenties te weinig aan bod zijn gekomen tijdens de opleiding, hebben de meeste oud-studenten deze competenties voornamelijk buiten of na de opleiding opgedaan of moeten opdoen (tabel 4.2). Het lijkt er overigens op dat oud-studenten hier in zijn geslaagd, want hun niveau van deze competenties is uiteindelijk min of meer toereikend voor het niveau dat vereist is in hun functie (tabel 4.1).

Volgens de oud-studenten heeft het vermogen om informatie te vergaren en presentaties te geven (meer dan) voldoende aandacht gekregen in de opleiding. Bij deze twee competenties hebben tenminste 20\%-punt méér oud-studenten aangegeven dat deze te veel aan bod zijn gekomen dan dat deze te weinig aan bod zijn gekomen.

\subsection{Gewenste nadruk op didactische werkvormen}

De werkvormen waarmee studenten tijdens de opleiding in aanraking komen spelen een belangrijke rol bij de competentieverwerving. Naast activerende onderwijsmethoden, zoals PGO, kunnen activerende werkvormen worden aangeboden, waardoor studenten de mogelijkheid krijgen om kennis en vaardigheden toe te passen op complexe problemen en in 'gesimuleerde' praktijksituaties. In de opleiding kan de mogelijkheid worden geboden om kennis in de praktijk te brengen middels bijvoorbeeld vaardigheidstrainingen, practica, schrijfopdrachten en onderzoeksopdrachten. Bransford e.a. (1989) en Glaser (1991) stellen dat het opdoen van ervaring met praktijkproblemen - of simulaties daarvan - een goede voorbereiding 
vormt op een beroep. Enerzijds leren studenten beter om te gaan met multidisciplinaire situaties of problemen en zijn ze vaker gestimuleerd om multidisciplinaire kennis toe te passen. Anderzijds zijn afgestudeerden die vaker in de gelegenheid zijn geweest om hun kennis en vaardigheden te trainen in een realistische context, beter voorbereid op de beroepspraktijk dan afgestudeerden die minder vaak gebruik hebben gemaakt van actieve werkvormen.

\section{Gewenste nadruk op (activerende) werkvormen}

Aan de oud-studenten is gevraagd om bij negen (activerende) werkvormen aan te geven of hierop tijdens de opleiding minder, gelijk of meer nadruk gelegd zou moeten worden (tabel 4.4). Als eerste valt op dat bij alle in de vragenlijst opgenomen werkvormen slechts een uiterst kleine minderheid opteert voor minder nadruk. Dit kan er op duiden dat oud-studenten door de bank genomen opteren voor meer 'contacturen' in de opleiding. Helaas was 'zelfstudie' als werkvorm niet opgenomen in de vragenlijst.

Tabel 4.4

Gewenste nadruk op werkvormen, FdEWB (\%)

\begin{tabular}{lrrr}
\hline & Minder nadruk & Gelijke nadruk & Meer nadruk \\
\hline Onderwijsgroepen & & & 4 \\
Hoorcolleges & 4 & 92 & 16 \\
Groepsopdrachten & 6 & 78 & 22 \\
Vaardigheidstrainingen & 16 & 61 & 63 \\
Practica & 6 & 31 & 47 \\
Presentatie/voordracht & 3 & 50 & 35 \\
Computersimulaties/-games & 8 & 56 & 56 \\
Schrijfopdrachten & 6 & 38 & 31 \\
Onderzoeksopdrachten & 8 & 60 & 52 \\
& 7 & 41 & \\
\hline
\end{tabular}

Een overduidelijke meerderheid van de geënquêteerde oud-studenten Economie is tevreden over de nadruk die in de opleiding wordt gelegd op onderwijsgroepen (92\%) en hoorcolleges (78\%). Enigszins verdeeld zijn de meningen over de gewenste nadruk op vaardigheidstrainingen en computersimulaties/-games. De meeste oudstudenten vinden dat de opleiding hier meer nadruk op zou moeten leggen. Echter, bij deze werkvormen is ook circa een derde van de oud-studenten tevreden over de nadruk die deze werkvormen hebben gekregen.

De geënquêteerde oud-studenten zijn ook enigszins verdeeld over de gewenste nadruk op presentaties/voordrachten en schrijfopdrachten. Hoewel de meerderheid tevreden is over de nadruk die op deze werkvormen wordt gelegd, vindt circa een derde van de oud-studenten dat presentaties/voordrachten en schrijfopdrachten meer nadruk zouden moeten krijgen. Ten aanzien van groepsopdrachten is het beeld nog diffuser: tegenover de meerderheid die tevreden is over de nadruk die op groepsopdrachten wordt gelegd, staat $22 \%$ die meer nadruk wenst en $16 \%$ die minder nadruk wenst. 
Duidelijk verdeeld zijn de onderzochte oud-studenten Economie over de gewenste nadruk op practica. Tegenover de $50 \%$ die tevreden is over de nadruk die op practica wordt gelegd, staat $47 \%$ die vindt dat practica meer nadruk zouden moeten krijgen. Ook ten aanzien van onderzoeksopdrachten zijn de meningen duidelijk verdeeld: tegenover de $52 \%$ die vindt dat onderzoeksopdrachten meer nadruk zouden moeten krijgen, staat $41 \%$ die tevreden is over de nadruk die op onderzoeksopdrachten wordt gelegd.

\section{Algemeen oordeel over de wijze van voorbereiding op de beroepspraktijk}

Aan de oud-studenten is ook gevraagd om op een vijfpuntschaal (van 'zeer oneens' $\mathrm{t} / \mathrm{m}$ 'zeer eens') aan te geven in welke mate zij het eens zijn met de uitspraak: "Ik ben over het algemeen tevreden over de wijze waarop de opleiding mij heeft voorbereid op de beroepspraktijk". Gebleken is dat $73 \%$ van de geënquêteerde oud-studenten Economie deze uitspraak onderschrijft (antwoordcategorie 4 en 5). De ruime meerderheid is dus tevreden over de wijze waarop de opleiding hen heeft voorbereid op de beroepspraktijk.

\subsection{Oordeel over scriptie en stage}

Aangezien de scriptie en stage belangrijke onderdelen ter voorbereiding op de arbeidsmarkt vormen, worden deze studieonderdelen in dit rapport afzonderlijk besproken. In de enquête zijn twee stellingen over het studieonderdeel scriptie en drie stellingen over het studieonderdeel stage geponeerd. Aan de oud-studenten is gevraagd in hoeverre zij het met de stellingen eens zijn. De antwoorden zijn gemeten op een vijfpuntschaal, lopend van 1 'zeer oneens' tot en met 5 'zeer eens'. In deze paragraaf worden de procentuele aandelen van de oud-studenten gepresenteerd, die het met de desbetreffende stelling eens zijn (antwoordcategorie 4 of 5). Uitgesloten van de percenteerbasis zijn oud-studenten die hebben aangeven dat de desbetreffende stelling voor hen niet van toepassing is.

Tabel 4.5

Oordeel over de scriptie, FdEWB: \% (zeer) met stelling eens*

\footnotetext{
- $\quad$ Aan de vaardigheden die ik tijdens de scriptie heb opgedaan, heb ik voldoende geleerd voor de praktijk

Het schrijven van een scriptie geeft een duidelijke meerwaarde aan de opleiding

Percentage oud-studenten dat 4 of 5 scoort op een schaal van 1 (zeer oneens) t/m 5 (zeer eens).

\section{Scriptie}

Een op de drie oud-studenten Economie vindt dat zij aan de vaardigheden, opgedaan bij het schrijven van de scriptie voldoende hebben geleerd voor de beroepspraktijk. lets meer dan de helft is van mening dat de scriptie een duidelijke meerwaarde aan de opleiding heeft gegeven.
} 
Tabel 4.6 laat zien dat alle geënquêteerde oud-studenten Economie tijdens hun opleiding stage hebben gelopen. Vrijwel iedereen vindt dat de stage een duidelijke meerwaarde geeft aan de opleiding. Wanneer we kijken naar de voorbereiding van de stage op de beroepspraktijk, dan zien we dat de helft van de oud-studenten Economie van mening is dat zij in de stage voldoende hebben geleerd voor de beroepspraktijk. Wat betreft de frequentie om stage te lopen, vindt ruim de helft van de oud-studenten dat stages vaker zouden mogen plaatsvinden.

Tabel 4.6

Oordeel over de stage, FdEWB: \% (zeer) met stelling eens*

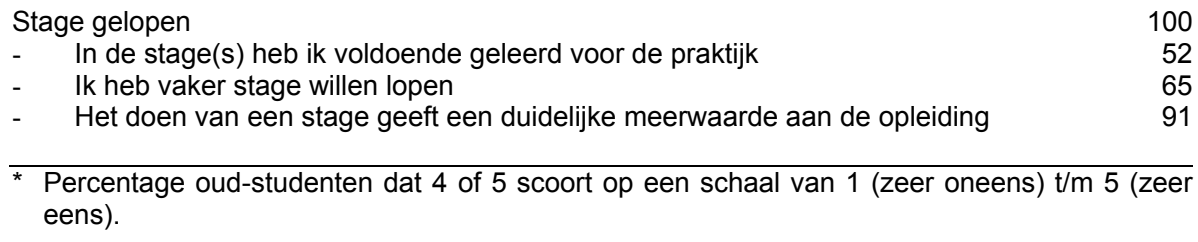

Ten aanzien van stages zij opgemerkt, dat de relevantie hiervan niet alleen ligt in de voorbereiding op de beroepspraktijk maar ook in het opbouwen van een netwerk dat na de opleiding behulpzaam kan zijn bij het vinden van werk.

\subsection{Gewenste inrichting van het curriculum}

In deze paragraaf wordt beschreven op welke wijze oud-studenten Economie het curriculum na een aantal jaren arbeidsmarktervaring zouden willen aanpassen. Aan de oud-studenten is gevraagd stelling te nemen ten aanzien van een aantal curriculumkenmerken. De respondenten dienden daarbij een keuze te maken tussen twee tegengestelde opties. Deze opties stonden aan de linker- en rechterkant op een antwoordschaal van 1 tot en met 7 . Een voorbeeld: "Als ik de opleiding zou mogen aanpassen, dan gaat mijn voorkeur uit naar meer theorie (antwoordcategorie $1 \mathrm{t} / \mathrm{m} \mathrm{3}$ ) of meer vaardigheden (antwoordcategorie $5 \mathrm{t} / \mathrm{m} 7$ )". Wanneer men de opleiding niet zou willen aanpassen diende men antwoordcategorie 4 aan te geven. In deze paragraaf worden figuren gepresenteerd, die aangeven waar de voorkeur van de oud-studenten naar uitgaat.

\section{Mate van specialisatie}

In de discussie over de inrichting van het onderwijs heeft het spanningsveld tussen een brede of een specialistische oriëntatie binnen opleidingen altijd een belangrijke rol gespeeld. Door het curriculum van een opleiding toe te spitsen op een specifiek beroep zijn de afgestudeerden optimaal voorbereid op dit beroep, en zal de productiviteit derhalve hoog zijn. Een nadeel van een dergelijke specialistische invulling van het onderwijs is echter dat de betreffende afgestudeerden sterk afhankelijk worden van de werkgelegenheidsontwikkeling van dit specifieke beroep. Om voldoende flexibiliteit op de arbeidsmarkt te kunnen waarborgen, is het vereist 
om de studenten breder op te leiden (Borghans \& De Grip, 1999, blz. 3). Daarbij is er in de praktijk, gegeven de beperkte studieduur, sprake van een spanningsveld tussen enerzijds het op een bepaald beroepsdomein gerichte specifieke vaktechnische karakter van een opleiding en anderzijds de competenties die een bredere inzetbaarheid op de arbeidsmarkt bewerkstelligen. In essentie gaat het hier om het spanningsveld tussen productiviteit en flexibiliteit. Tussen deze twee doelstellingen, productiviteit en flexibiliteit, dient een afweging te worden gemaakt (Borghans \& De Grip, 1999, blz. 26-27).

In de discussie over de inrichting van het onderwijs lijkt een golfbeweging te bestaan tussen enerzijds de roep om bredere kwalificaties en anderzijds de roep om beter toegeruste vakspecialisten. Met name de sterke technologische en organisatorische veranderingen van de laatste jaren hebben geleid tot een roep om werknemers met een hoge employability en sleutelkwalificaties, die niet zijn aangewezen op een specifiek beroep maar in een breder beroependomein inzetbaar zijn (Borghans \& De Grip, 1999, blz. 4).

In welke mate oud-studenten Economie, achteraf bezien, een meer generiek dan wel meer specialistisch studieprogramma voorstaan, staat weergegeven in figuur 4.1. Uit de figuur komt duidelijk naar voren dat de geënquêteerde oud-studenten Economie een duidelijke voorkeur hebben voor een breed studieprogramma (55\%) boven een meer specialistisch curriculum (23\%). Een op de vijf (21\%) oud-studenten Economie is tevreden over de breedte van het curriculum.

Figuur 4.1

Breed versus specialistisch curriculum gewenst, FdEWB (\%)
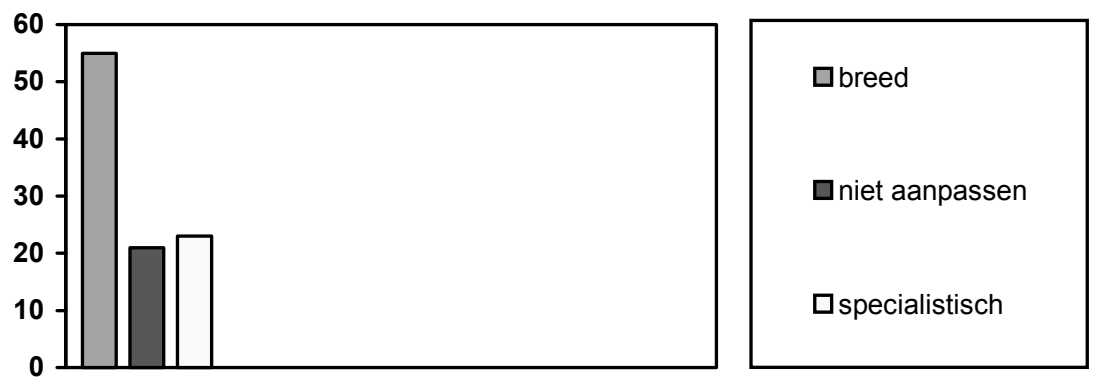

\section{Beroepsgerichtheid}

Figuur 4.2 laat zien dat oud-studenten Economie uiterst verdeeld zijn in hun voorkeur voor een meer academische dan wel meer beroepsgerichte oriëntatie van het curriculum: 38\% staat een meer academisch gerichte opleiding voor, en eveneens $38 \%$ een meer beroepsgerichte opleiding. Een kwart van de geënquêteerde oudstudenten $(25 \%)$ zou het curriculum niet aanpassen wat de academische versus beroepsgerichte oriëntatie betreft. 
Figuur 4.2

Academisch versus beroepsgericht curriculum gewenst, FdEWB (\%)
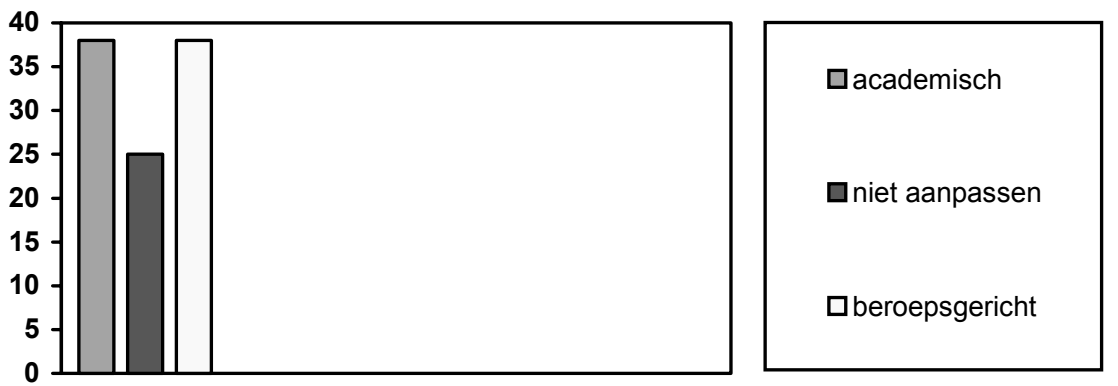

\section{Praktijkgerichtheid}

Hoeveel oud-studenten meer praktijkervaring zouden inbouwen in de opleiding, dan wel meer theoretische vakken zouden opnemen in het onderwijsprogramma, wordt weergegeven in figuur 4.3. Deze laat zien dat verreweg de meeste respondenten $(69 \%)$ meer praktijkervaring zouden inbouwen in de opleiding, terwijl vrijwel niemand $(8 \%)$ meer theoretische vakken in het curriculum zou opnemen. Bijna een kwart $(23 \%)$ is tevreden over de verhouding tussen gerichtheid op praktijkervaring en theoretische gerichtheid van de opleiding.

Figuur 4.3

Meer praktijkervaring versus meer theoretische vakken, gewenst FdEWB (\%)

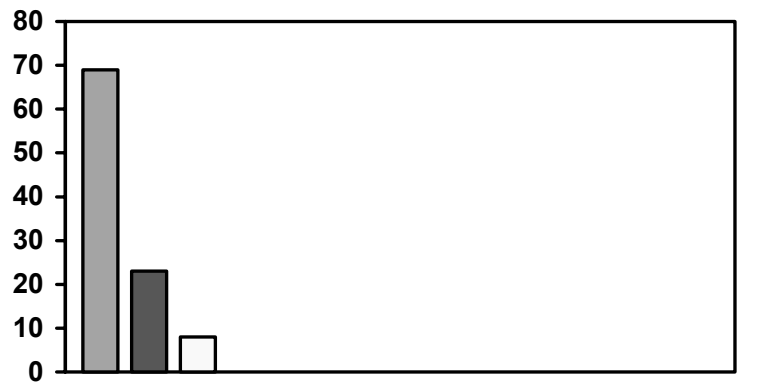

$$
\begin{aligned}
& \square \text { meer praktijkervaring } \\
& \square \text { niet aanpassen } \\
& \begin{array}{l}
\square \text { meer theoretische } \\
\text { vakken }
\end{array}
\end{aligned}
$$

\section{Oriëntatie op vaardigheden}

Wat de verhouding tussen theorie en vaardigheden betreft, komt uit figuur 4.4 het volgende beeld naar voren. Verreweg de meeste oud-studenten Economie (63\%) zouden het curriculum aanpassen door meer nadruk te leggen op vaardigheden, terwijl vrijwel niemand (8\%) het curriculum zou aanpassen door meer de nadruk te leggen op theorie. Bijna een derde (29\%) van de geënquêteerde oud-studenten is tevreden over de verhouding tussen theorie en vaardigheden in de opleiding. 
Figuur 4.4

Meer theorie versus meer vaardigheden gewenst, FdEWB (\%)

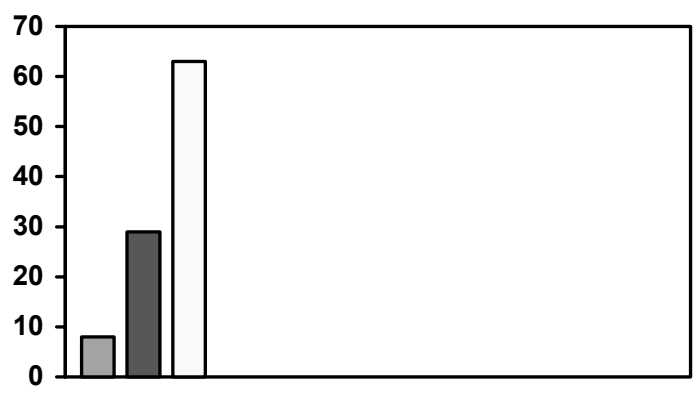

口meer theorie

口niet aanpassen

口meer vaardigheden

\section{Soort vaardigheden}

Wanneer we kijken naar het soort vaardigheden dat oud-studenten zouden willen kiezen, dan zien we in figuur 4.5 dat oud-studenten Economie uiterst verdeeld zijn in hun voorkeur voor meer beroepsspecifieke vaardigheden (33\%) dan wel meer algemene vaardigheden (36\%). Een op de drie oud-studenten (31\%) zou het curriculum niet aanpassen wat de oriëntatie op algemene dan wel beroepsspecifieke vaardigheden betreft.

\section{Figuur 4.5}

Meer algemene versus meer beroepsspecifieke vaardigheden gewenst, FdEWB (\%)
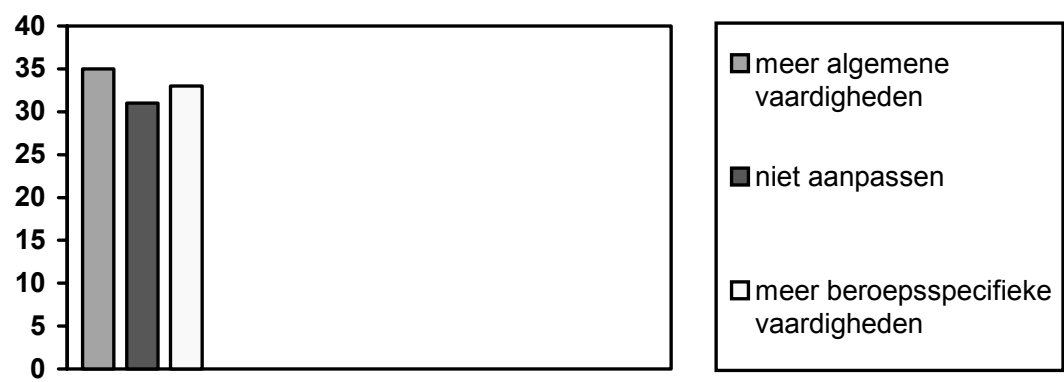

\section{Vrijheid bij vakkenkeuze}

Figuur 4.6 toont de voorkeur van oud-studenten Economie ten aanzien van de vrijheid bij het samenstellen van het vakkenpakket. Exact de helft van de geënquêteerde oud-studenten is tevreden over de vrijheid van vakkenkeuze. Binnen de andere helft die over de vrijheid van vakkenkeuze ontevreden is, vormen de voorstanders van meer keuzevrijheid (35\%) een duidelijk grotere groep dan degenen die vinden dat er minder vrijheid moet zijn in de keuze van vakken (15\%). 
Figuur 4.6

Gewenste vrijheid bij vakkenkeuze, FdEWB (\%)

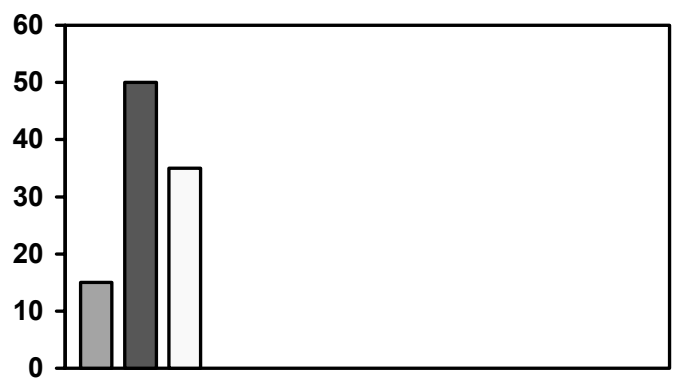

口minder vrijheid

口niet aanpassen

口meer vrijheid

\section{Moeilijkheidsgraad}

Vooral ten gevolge van de verdergaande stijging van de opleidingseisen binnen veel beroepsgroepen is de vraag naar hoger opgeleiden de afgelopen jaren sterk toegenomen. Uit internationaal onderzoek blijkt dat met name de toenemende internationalisering en de daaraan gerelateerde organisatorische veranderingen een belangrijke oorzaak vormen van de toegenomen kwalificatievereisten. De snelle technologische ontwikkelingen leiden tot een toenemende complexiteit van veel functies. Daarnaast bewerkstelligen technologische ontwikkelingen vaak ook organisatorische veranderingen, zoals het schrappen van managementlagen, decentralisering, 'empowerment', e.d. die op hun beurt de kwalificatie-eisen verder doen stijgen. Een belangrijke rol speelt daarbij dat massaproductie in alle sectoren plaats maakt voor op de consument afgestemd maatwerk en een toenemend belang van de kwaliteit van de geleverde goederen en diensten. Het laatste resulteert in de toegenomen aandacht voor kwaliteitszorg, die doorgaans leidt tot meer aandacht voor het belang van goed geschoold personeel (ROA, 1999, blz. 6).

Figuur 4.7

Gewenste zwaarte van het studieprogramma, FdEWB (\%)
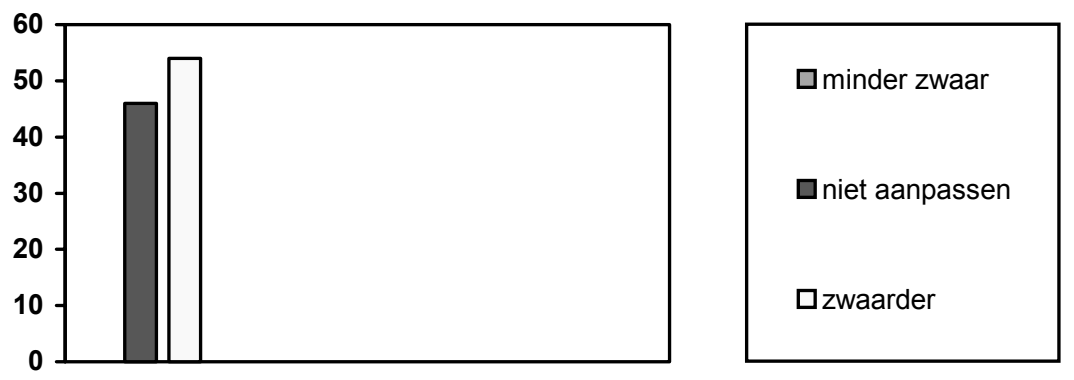

De toenemende kwalificatie-eisen verklaren wellicht waarom niemand van de geënquêteerde oud-studenten Economie een minder zwaar studieprogramma voorstaat. In tegendeel, meer dan de helft (54\%) van de oud-studenten is van 
mening dat het curriculum best zwaarder mag zijn (figuur 4.7). Bijna de helft (46\%) van de geënquêteerde oud-studenten is echter tevreden over de zwaarte van het studieprogramma en wil deze dan ook niet aanpassen.

Bij de bevinding dat meer dan de helft een zwaarder programma voorstaat, dient te worden opgemerkt dat dit de mening van afgestudeerden betreft, dus van degenen die de opleiding aan de UM destijds met diploma hebben voltooid. Oud-studenten die destijds hun opleiding voortijdig hebben verlaten zullen wellicht een andere mening zijn toegedaan.

\section{Buitenlandoriëntatie}

In het licht van de toenemende internationalisering van onze samenleving bieden universiteiten aan studenten steeds vaker de mogelijkheid om een deel van de studie, een stage of een project in het buitenland te volgen. Buitenlandervaring, opgedaan tijdens de opleiding, kan van belang zijn voor de wijze waarop de transitie van studie naar werk en de verdere ontwikkeling van de beroepscarrière verloopt. Zo blijkt uit onderzoek onder universitaire afgestudeerden dat oud-studenten die tijdens hun opleiding buitenlandervaring hebben opgedaan veel vaker op zoek gaan naar werk in het buitenland en ook vaker daadwerkelijk in het buitenland gaan werken dan oud-studenten zonder buitenlandervaring (Meng \& Ramaekers, 2000). Uit het onderzoek van Meng en Ramaekers onder universitaire afgestudeerden blijkt verder dat buitenlandervaring tijdens de opleiding bij afgestudeerden van economische en technische opleidingen tot een verhoging van hun productieve waarde leidt.

Wat de gewenste aanpassingen van de opleiding betreft, is ten slotte gevraagd naar de mate waarin naar de mening van de oud-studenten buitenlandervaring moet worden ingebouwd in het opleidingsprogramma (figuur 4.8). De toenemende internationalisering van onze samenleving verklaart wellicht waarom vrijwel niemand $(2 \%)$ van de oud-studenten de mogelijkheid om buitenlandervaring in de opleiding op te doen wil reduceren. In tegendeel, meer dan de helft (52\%) van de oud-studenten wenst meer buitenlandervaring in de opleiding. Bijna de helft (46\%) is echter tevreden over de mate waarin de opleiding voorziet in het opdoen van buitenlandervaring.

Figuur 4.8

Gewenste buitenlandervaring in de opleiding, FdEWB (\%)

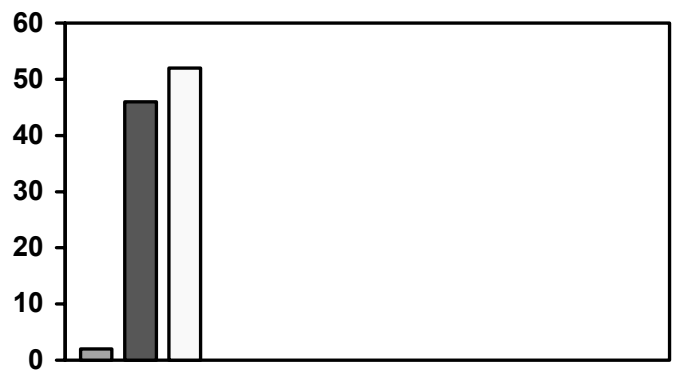

$$
\begin{aligned}
& \square \text { minder } \\
& \text { buitenlandervaring } \\
& \square \text { niet aanpassen } \\
& \square \text { meer } \\
& \text { buitenladervaring }
\end{aligned}
$$




\subsection{Oordeel over voorbereiding op beroepspraktijk}

\section{Oordeel over startbekwaamheid en potentieel voor verdere ontwikkeling}

Aan de oud-studenten is gevraagd om op een vijfpuntschaal (van 'zeer oneens' $t / m$ 'zeer eens') aan te geven in welke mate zij het eens zijn met de stelling dat de opleiding hen startbekwaam heeft gemaakt voor de arbeidsmarkt en een basis heeft verschaft om zich beroepsmatig verder te ontwikkelen. Tabel 4.7 toont het procentuele aandeel van de oud-studenten die de stelling onderschrijven dat de opleiding een goede basis biedt (antwoordcategorie 4 of 5) om te starten op de arbeidsmarkt respectievelijk kennis en vaardigheden verder te ontwikkelen.

Tabel 4.7

Oordeel over de voorbereiding op de beroepspraktijk, FdEWB: \% (zeer) met stelling eens*

De kennis en vaardigheden die ik tijdens de opleiding heb verworven, zijn voldoende om adequaat te starten in de beroepspraktijk

De opleiding biedt voldoende basis voor het verder ontwikkelen van kennis en vaardigheden

* Percentage oud-studenten dat 4 of 5 scoort op een schaal van 1 (zeer oneens) t/m 5 (zeer eens).

Zes van de tien oud-studenten Economie vinden dat de opleiding hen afdoende heeft toegerust om adequaat te kunnen starten in de beroepspraktijk. Dit betekent dat vier van de tien oud-studenten - achteraf terugblikkend - van mening zijn dat hun startbekwaamheid onvoldoende was. Dit hoeft overigens niet problematisch te zijn geweest voor hun verdere beroepsmatige ontwikkeling. Immers, vrijwel alle oudstudenten vinden - achteraf terugblikkend - dat de opleiding een voldoende basis heeft geboden om kennis en vaardigheden verder te kunnen ontwikkelen, bijvoorbeeld via nascholing.

In tabel 4.8 wordt de startbekwaamheid nader gespecificeerd door na te gaan in hoeverre oud-studenten Economie bij de overgang naar de beroepspraktijk tekorten in theoretische kennis, praktische vaardigheden en omgang met praktijkproblemen/situaties hebben ervaren. Vervolgens wordt in tabel 4.9 nagegaan of nascholing nodig was vanwege tekortkomingen in de opleiding.

Bij de start op de arbeidsmarkt ervaren opleidingstekorten

Aan de oud-studenten zijn drie stellingen voorgelegd, die verwijzen naar eventuele tekorten in theoretische kennis, praktische vaardigheden en praktijkervaring die zij bij de overgang naar de beroepspraktijk hebben ervaren. Tabel 4.8 toont hoeveel procent van de oud-studenten het met de drie stellingen eens is (antwoordcategorie 4 of 5 , gemeten op een vijfpuntschaal van: 'zeer oneens' $t / m$ 'zeer eens').

Uit tabel 4.7 is naar voren gekomen dat $38 \%$ van de geënquêteerde oud-studenten vindt dat de opleiding hen onvoldoende heeft toegerust om adequaat te kunnen starten in de beroepspraktijk. Uit tabel 4.8 blijkt dat het hierbij vooral gaat om 
tekorten in praktische vaardigheden en omgang met praktijkproblemen/-situaties, en niet om tekorten in theoretische kennis.

Tabel 4.8

Ervaren tekorten bij de overgang naar de beroepspraktijk, FdEWB: \% (zeer) met stelling eens *

Bij de overgang naar de beroepspraktijk heb ik tekorten ervaren in theoretische kennis $\quad 9$

Bij de overgang naar de beroepspraktijk heb ik tekorten ervaren in praktische

vaardigheden

Tijdens mijn opleiding ben ik voldoende in aanraking geweest met praktijkproblemen en praktijksituaties

* Percentage oud-studenten dat 4 of 5 scoort op een schaal van 1 (zeer oneens) t/m 5 (zeer eens).

\section{Belang van nascholing}

$\mathrm{Na}$ het afstuderen houdt het verwerven van kennis en vaardigheden niet op. Mede gezien de veranderingen in de arbeidsmarkt en de daaruit voortkomende veranderingen in de gewenste competenties, mag worden verwacht dat er behoefte blijft bestaan aan bijscholing. Tegen deze achtergrond zijn drie stellingen, die betrekking hebben op de noodzaak van nascholing, voorgelegd aan de oud-studenten. Tabel 4.9 toont hoeveel procent van de oud-studenten het met de drie stellingen eens is (antwoordcategorie 4 of 5 , gemeten op een vijfpuntschaal van: 'zeer oneens' $t / m$ 'zeer eens').

Tabel 4.9

Oordeel over de relevantie van nascholing, FdEWB: \% (zeer) met stelling eens*

Nascholing is nodig vanwege tekortkomingen in mijn opleiding

Nascholing is nodig om kennis en vaardigheden op te doen die beter te leren zijn in combinatie met werk

Nascholing is nodig vanwege nieuwe ontwikkelingen die niet te voorzien waren tijdens mijn opleiding

* Percentage oud-studenten dat 4 of 5 scoort op een schaal van 1 (zeer oneens) t/m 5 (zeer eens).

Hoewel $38 \%$ van de geënquêteerde oud-studenten Economie vindt dat de opleiding hen onvoldoende heeft toegerust om adequaat te kunnen starten in de beroepspraktijk (tabel 4.7), onderschrijft 'slechts' $7 \%$ van hen de stelling dat nascholing nodig is vanwege tekortkomingen in de opleiding. Blijkbaar wordt onvoldoende startbekwaamheid doorgaans niet beschouwd als een tekortkoming van de opleiding. Het lijkt er eerder op dat oud-studenten de opleiding eerder 'afrekenen' op hun vermogen om kennis en vaardigheden verder te ontwikkelen dan op hun startbekwaamheid. Immers, in tabel 4.7 hebben we kunnen zien dat vrijwel alle oudstudenten van mening zijn dat de opleiding een voldoende basis heeft geboden om kennis en vaardigheden verder te kúnnen ontwikkelen, bijvoorbeeld via scholing. Het gaat dan om kennis en vaardigheden die beter te leren zijn in combinatie met werk of om nieuwe ontwikkelingen die niet te voorzien zijn tijdens de opleiding (tabel 4.9). Uit onderzoek van het ROA is gebleken dat bijvoorbeeld managementvaardigheden 
beter te leren zijn in combinatie met werk dan in het initiële onderwijs (Heijke, Meng \& Ramaekers, 2003, Heijke, Ramaekers \& Ris, 2004).

\subsection{Conclusies en aanbevelingen}

Aan het onderzoek hebben 63 oud-studenten Economie deelgenomen, wat neerkomt op een respons van $21 \%$. De analyse is echter beperkt tot 49 oud-studenten Economie, namelijk degenen die werkzaam zijn in functies waarvoor de opleiding beoogde op te leiden.

Bij de opleidingspecifieke competenties manifesteren zich nauwelijks of geen discrepanties tussen het niveau van competenties dat vereist is in de functie en het 'eigen' competentieniveau van de onderzochte oud-studenten Economie. Wat betreft de kennis van andere vakgebieden, het vermogen om aan anderen duidelijk te maken wat men bedoelt alsmede de bereidheid om op te komen voor het eigen standpunt, begrip te tonen voor andere standpunten en feedback te ontvangen/ geven, schatten de geënquêteerde oud-studenten hun eigen niveau iets lager in dan het niveau dat vereist is in hun functie.

Wordt aan oud-studenten echter gevraagd waar de opleiding méér nadruk op zou moeten leggen, dan antwoorden zij: op het vermogen om vakkennis in de praktijk toe te passen, conform budget en planning te werken, besluiten te nemen, in conflictsituaties adequaat te reageren, en leiding te geven. Wellicht omdat deze competenties te weinig aan bod zijn gekomen tijdens de opleiding, hebben de meeste oud-studenten deze competenties voornamelijk buiten of na de opleiding opgedaan of moeten opdoen. Het lijkt er overigens op dat oud-studenten hier in zijn geslaagd, want hun niveau van deze competenties is uiteindelijk min of meer toereikend voor het niveau dat vereist is in hun functie. Wat volgens de oudstudenten (meer dan) voldoende aandacht heeft gekregen in de opleiding is het vermogen om informatie te vergaren en presentaties te geven.

Over de wijze waarop de opleiding hen heeft voorbereid op de beroepspraktijk is driekwart van de geënquêteerde oud-studenten Economie tevreden. Vooral over de nadruk die in de opleiding wordt gelegd op onderwijsgroepen en hoorcolleges is een overduidelijke meerderheid van de respondenten tevreden. Echter, op vaardigheidstrainingen en computersimulaties/-games zou volgens de meeste oud-studenten méér nadruk gelegd moeten worden.

De stage wordt als voorbereiding op de beroepspraktijk positiever beoordeeld dan de scriptie. Een derde van de geënquêteerde oud-studenten Economie vindt dat zij aan de vaardigheden, opgedaan tijdens het schrijven van de scriptie voldoende hebben geleerd voor de beroepspraktijk. lets meer dan de helft is van mening dat de scriptie een duidelijke meerwaarde aan de opleiding heeft gegeven. De stage echter wordt door bijna alle respondenten Economie als meerwaarde voor de opleiding gezien. De helft van de oud-studenten vindt dat zij in de stage voldoende heeft geleerd voor de praktijk. Deze positieve beoordeling van het nut van stages verklaart wellicht waarom 
twee van de drie oud-studenten vinden dat er meer mogelijkheden zouden moeten zijn om stage te kunnen lopen.

Circa de helft van de geënquêteerde oud-studenten is tevreden over de vrijheid van de vakkenkeuze, de zwaarte van de opleiding en de mate waarin de opleiding voorziet in het opdoen van buitenlandervaring. Binnen de andere helft overheersen de voorstanders van meer keuzevrijheid, een zwaarder programma en meer buitenlandervaring in de opleiding. Uiterst verdeeld zijn oud-studenten als het gaat om hun voorkeur voor een meer academische dan wel meer beroepsgerichte oriëntatie van het curriculum, en als het gaat om het benadrukken van meer beroepsspecifieke dan wel meer algemene vaardigheden in de opleiding.

Er zijn wel een paar punten die de meeste respondenten zouden willen aanpassen in de oriëntatie van het curriculum. Ten eerste hebben de oud-studenten een duidelijke voorkeur voor een breed programma boven een meer specialistisch programma. Een tweede punt van aandacht is de voorkeur van oud-studenten voor het inbouwen van meer praktijkervaring in plaats van meer theoretische vakken in het curriculum. Ten derde zouden verreweg de meeste geënquêteerde oud-studenten Economie het curriculum aanpassen door meer de nadruk te leggen op vaardigheden in plaats van op meer theorie.

Vier van de tien oud-studenten Economie vinden dat de opleiding hen onvoldoende heeft toegerust om adequaat te kunnen starten in de beroepspraktijk. Het gaat hierbij vooral om tekorten in praktische vaardigheden en omgang met praktijkproblemen/situaties, en niet om tekorten in theoretische kennis. Dit hoeft overigens niet problematisch te zijn voor hun verdere beroepsmatige ontwikkeling. Immers, vrijwel alle geënquêteerde oud-studenten vinden dat de opleiding een goede basis heeft gelegd om kennis en vaardigheden verder te kunnen ontwikkelen. Het is dan ook niet verwonderlijk dat de overgrote meerderheid van de respondenten niét vindt dat nascholing nodig is vanwege tekortkomingen in de opleiding, maar dat nascholing doorgaans nodig is vanwege nieuwe ontwikkelingen die niet te voorzien zijn tijdens de opleiding, of om kennis en vaardigheden op te doen die beter te leren zijn in combinatie met werk.

Kort samengevat luiden de aanbevelingen ${ }^{4}$ van de geënquêteerde oud-studenten Economie voor aanpassingen in het curriculum:

- In de opleiding meer aandacht besteden aan het vermogen om besluiten te nemen en in conflictsituaties adequaat te reageren. Hierbij zij opgemerkt dat oudstudenten ook aanbevelen om meer aandacht te besteden aan het vermogen om vakkennis in de praktijk toe te passen, conform budget en planning te werken en leiding te geven. Echter, bij deze competenties blijkt hun niveau toereikend te zijn voor het niveau dat vereist is in hun functie;

- Liever een breder studieprogramma aanbieden dan een meer specialistisch programma;

4. De hier gepresenteerde aanbevelingen zijn niet geordend naar belangrijkheid. 
- Liever meer praktijkervaring inbouwen in de opleiding dan meer theoretische vakken opnemen in het curriculum;

- Liever streven naar meer vaardigheden dan naar meer theorie;

- In de opleiding een zwaarder accent leggen op vaardigheidstrainingen;

- Meer stagemogelijkheden bieden. 



\section{Evaluatie van het project Curriculumevaluatie}

Uit evaluatiegesprekken naar aanleiding van de eerste fase van het project Curriculumevaluatie is gebleken dat de informatie vanuit de beroepspraktijk over de gewenste inrichting van het curriculum die met behulp van het onderzoeksinstrument wordt verkregen, goed bruikbaar bleek voor de opleiders van de FdGW en FdCW. Mede naar aanleiding van deze positieve ervaringen is met ingang van 2003 de standaard $t+1$ meting verbeterd door twee curriculumvragen toe te voegen. Het gaat om de vragen die betrekking hebben op de relevantie van onderwijsmethoden en onderwijswerkvormen. So far, so good! De tweede fase van het project heeft echter ook aangetoond dat de gehanteerde onderzoeksopzet qua respons niet goed werkt.

\section{Teleurstellende respons onder oud-studenten}

Het aanhaken van het project Curriculumevaluatie aan de reguliere $t+5$ enquête onder oud-studenten lijkt een sterk responsverlagend effect te hebben gehad. De $t+5$-lijst is in 2003 door het toevoegen van een omvangrijk blok vragen in het kader van het project Curriculumevaluatie ${ }^{5}$ beduidend langer geworden, met als gevolg dat veel oud-studenten afhaken. Een aanwijzing hiervoor is de sterk teruggelopen respons ten opzichte van de in 2002 gehouden $t+5$ meting (zonder het extra vragenblok over curriculumevaluatie), en wel van $42 \%$ naar $28 \%$ : een daling met maar liefst 14\%-punt. Deze teruggang in respons is beduidend groter dan bij de $t+10$ meting, waarin de respons ten opzichte van de in 2002 gehouden meting is teruggelopen van $37 \%$ naar $34 \%$ (een daling met 3\%-punt).

\section{Teleurstellende respons in de werkgeversenquête}

Aangezien van alle faculteiten alleen de FdEWB behoefte had om inzicht te krijgen in de wensen van werkgevers ten aanzien van de oud-studenten, is alleen voor de FdEWB de meting onder oud-studenten in het kader van het project Curriculumevaluatie uitgebreid met een meting onder hun werkgevers. Gekozen is om de werkgevers via de oud-studenten van de FdEWB te benaderen, waarbij de oudstudenten is gevraagd om de werkgeversvragenlijst aan hun directe leidinggevende door te geven. Helaas bedroeg de respons in deze werkgeversenquête slechts $4,6 \%$ van het totale aantal benaderde oud-studenten.

Een brede waaier van factoren blijkt een rol te spelen bij deze teleurstellend lage respons in de werkgeversenquête. Geen interesse van de zijde van oud-studenten om de werkgeversvragenlijst door te geven is slechts één van die factoren. Voor de UM in het algemeen en de economische faculteit in het bijzonder zouden een verouderd adres en het feit dat leidinggevenden niet altijd Nederlandstalig zijn een bijzondere rol kunnen spelen. Daarnaast blijkt uit een vergelijkbaar project dat het ROA voor Hogeschool INHOLLAND heeft uitgevoerd, dat de respons afneemt

5. Vragenblok $F$ van de in bijlage 1 opgenomen vragenlijst. 
naarmate men langer is afgestudeerd. ${ }^{6}$ De pilot voor INHOLLAND had betrekking op oud-studenten die twee of drie jaar tevoren waren afgestudeerd, terwijl de UM'ers in dit onderzoek al zes jaar geleden zijn afgestudeerd. Dit aspect zou bij de UM dus een grote rol kunnen spelen. Deels heeft dit te maken met verouderde adressen, maar wellicht ook met een afnemende binding met de opleiding. Ten slotte is de combinatie van een uitgebreide vragenlijst voor de afgestudeerde zelf en het verzoek een werkgeversvragenlijst door te geven aan de direct leidinggevende mogelijk iets teveel gevraagd. Een aanwijzing hiervoor is dat ook de respons onder de oudstudenten zelf negatief lijkt te zijn beïnvloed. Zo laten de cijfers in tabel 5.1 zien dat de respons onder oud-studenten van de FdEWB in de gecombineerde afgestudeerden-werkgevers meting (meting 2003) meer dan gehalveerd is ten opzichte van de meting zonder werkgeversbenadering (meting 2002). Deze daling is beduidend groter dan de daling bij de andere faculteiten, die niet hebben deelgenomen aan een pilot onder werkgevers.

Tabel 5.1

Respons loopbaanmeting na 5,5 jaar onder oud-studenten van de UM (\%)

\begin{tabular}{lcc} 
& Meting 2002 & Meting 2003 \\
\hline FdCW & 57 & 30 \\
FdEWB & 49 & $21^{*}$ \\
FdG & 54 & 32 \\
FdGW & 43 & 36 \\
FdR & 31 & 22 \\
Totaal UM & 42 & 28 \\
\hline
\end{tabular}

* Gecombineerde afgestudeerden-werkgevers enquête.

\section{Aanbevelingen}

Het feit dat de betrokkenen van de faculteiten in de eerste fase van het project de resultaten van het curriculumonderzoek positief hebben beoordeeld, geeft de wenselijkheid aan om het ontwikkelde vragenblok over de evaluatie van het curriculum systematisch in te zetten om de faculteiten periodiek op de hoogte te houden over de opvattingen van alumni over het door hen gevolgde curriculum. Een beperkende factor hierbij vormt de lengte van de vragenlijst.

Om de respons onder oud-studenten te verbeteren, is het raadzaam de vragenlijst kritisch onder de loep te nemen. Zelfs zonder het extra vragenblok over de evaluatie van het curriculum is met de huidige omvang een grens bereikt. Een bondiger vragenlijst is dan ook wenselijk. Dit kan alleen door het vragenblok over curriculumevaluatie los te koppelen van de vragenlijst over de loopbaan, dus om de meting over curriculumevaluatie los te koppelen van de meting over de loopbaan.

6. Uit het project bij Hogeschool INHOLLAND is gebleken dat de 'bottleneck' voor medewerking aan het onderzoek zich bij de oud-studenten heeft voorgedaan en niet bij hun werkgevers. 
Het is overigens ook raadzaam om de omvang van de loopbaanvragenlijst zelf kritisch onder de loep te nemen.

In een breder kader van het schoolverlaters- en loopbaanonderzoek denkt het ROA bovendien na over een andere opzet van de dataverzameling. Internet speelt daarbij een belangrijke rol. Via Internet komen allerlei nieuwe manieren beschikbaar om het onderzoek aantrekkelijker te maken voor de oud-studenten. Beoogd wordt hen daarmee te prikkelen de vragenlijst in te vullen. Zo wordt het mogelijk feedback te geven, op maat gesneden informatie toe te sturen over bijvoorbeeld de arbeidsmarktpositie van de afgestudeerden van hun jaargang of studierichting en de oud-studenten op de hoogte te houden over de voortgang van het onderzoek. Benadering via Internet maakt het ook mogelijk om het onderzoek onder oudstudenten flexibeler op te zetten, bijvoorbeeld om de meting over curriculumevaluatie los te koppelen van de meting over de loopbaan. Daarbij komt dat de kosten van dataverzameling voor het reguliere loopbaanonderzoek onder oud-studenten niet noemenswaardig stijgen wanneer additioneel een vragenlijst curriculumevaluatie via Internet wordt afgenomen. Op deze wijze zouden de faculteiten periodiek op de hoogte kunnen worden gehouden over de opvattingen van alumni over het door hun gevolgde curriculum.

\section{Aanbevelingen ten aanzien van de meting onder werkgevers}

Met betrekking tot de werkgeversenquête moet de belangrijkste conclusie uit de pilot bij zowel de Hogeschool INHOLLAND als de FdEWB luiden dat een benadering van het werkveld via de oud-studenten tot een te lage en niet-representatieve respons leidt. De gekozen onderzoeksopzet is waarschijnlijk debet aan de teleurstellende respons. Gezien de toegevoegde waarde voor het onderzoek naar de transitie van school naar werk en de belangrijke inzichten die het raadplegen van werkgevers kan opleveren in het kader van curriculumevaluatie en kwaliteitszorg, blijft werkgeversonderzoek wenselijk. Wellicht een betere optie, dan de bij deze pilots gehanteerde opzet, is om in de enquête onder afgestudeerden te vragen naar de naam en het adres van de werkorganisatie en later, los van de afgestudeerden-enquête, de werkgevers rechtstreeks te benaderen. 



\section{Literatuur}

Borghans, L. \& Grip, A. de (1999), Smal en breed opleiden: productiviteit versus flexibiliteit, Gids voor de opleidingspraktijk, afl. 28, Samsom, Deventer.

Bransford, J.D., Franks, J.J., Vye, N.J. \& Sherwood, R.D. (1989), New approaches to instruction: because wisdom can't be told, in: Vosniadou, S. \& Ortony, A. (eds.), Similarity and Analogical reasoning, Cambridge University Press, Cambridge.

Delden, P. van (1997), Professional: kwaliteit van het beroep, Contact Amsterdam, Amsterdam.

Glaser, R. (1991), The maturing of the relationship between science of learning and cognition and educational practice, Learning and Instruction, No.1, 129-144.

Heijke, H., Meng, C. \& Ramaekers, G. (2003), An investigation into the role of human capital competences and their pay-off, in: International Journal of Manpower, Vol. 24, No. 7, pp. 750773.

Heijke, H., Ramaekers, G. \& Ris, C. (2004), Do business administration studies offer better preparation for supervisory positions than traditional economics studies?, te verschijnen in: Education Economics, Vol. 12, No. 1.

Jacob-Tacken, K. \& Vaatstra, R. (2001), Evaluatie van het Curriculum Gezondheidswetenschappen en Cultuurwetenschappen, Pilot Project, ROA, Maastricht.

Meng, C.M. \& Ramaekers, G.W.M. (2000), Effecten van buitenlandervaring tijdens de studie op de loopbaan van academici, Beleidsgerichte studies Hoger onderwijs en Wetenschappelijk onderzoek 73, Ministerie van Onderwijs, Cultuur en Wetenschappen, Den Haag.

Nedermeijer, J. \& Pilot, A. (2000), Beroepscompetenties en academische vorming in het hoger onderwijs, HOR-Reeks, Groningen: Wolters-Noordhoff.

Researchcentrum voor Onderwijs en Arbeidsmarkt (1999), De arbeidszmarkt naar opleiding en beroep tot 2004, ROA, Maastricht.

Vries, M.R. de \& Eijs, P.W.L.J. van (2004), Loopbanen na de Universiteit Maastricht: meting 2003, ROA, Maastricht.

Webbink, D. \& Paape, A. (1997), De dynamische relatie tussen hoger onderwijs en arbeidsmarkt, Beleidsgerichte studies Hoger onderwijs en Wetenschappelijke onderzoek 46 Ministerie OC\&W, Den Haag.

Weggeman, M.C.D.P. (1997), De onzekerheid van de digitale leeromgeving. In: M. Mirande, De digitale leeromgeving, HOR-reeks, Groningen: Wolters-Noordhoff. 

Bijlage 1 



\section{Vragenlijst Universiteit Maastricht (UM) \\ - Afstudeerjaar 1996/1997}

\section{Toelichting}

- Kruis steeds maar één antwoord aan, tenzij uitdrukkelijk anders is aangegeven.

- Antwoorden op open vragen op de aangegeven stippellijntjes noteren.

- Let goed op naar welke vraag u wordt doorverwezen. Een aantal vragen hoeft u misschien niet in te vullen.

\section{A. Gevolgde opleidingen}

\section{Vooropleiding}

A 1a Wat is uw hoogste met diploma afgesloten schoolopleiding vóór uw eerste inschrijving in het WO?

A 1b Hoe hoog waren uw eindexamencijfers voor deze vooropleiding?

\section{WO-opleiding afstudeerjaar 1996/1997}

A 2a Welke WO-opleiding heeft $u$ in afstudeerjaar 1996/1997 aan de UM afgerond?

A 2b

Heeft u de voltijd- of deeltijd-variant van deze opleiding gevolgd?

Wanneer behaalde $u$ het diploma van deze opleiding?

A 2d Hoe bent $u$ aan deze WO-opleiding begonnen?

A 2 e Wanneer heeft $u$ zich voor het eerst voor deze WO-opleiding ingeschreven?

(Let op: inclusief de eventuele in vraag A $2 d$ genoemde (eigen of andere) WO-propedeuse)

A $2 f$ Heeft $u$ vóór of tijdens deze WO-opleiding nog een andere WO-opleiding afgerond?

A 3a Heeft u vóór of tijdens uw WO-opleiding voor uw vakgebied relevante werkervaring opgedaan? - zowel betaald als onbetaald werk telt mee. -stage(s), afstudeeropdracht e.d. tellen niet mee.

A 3b Heeft u vóór of tijdens uw WO-opleiding bestuurlijke ervaring opgedaan?

A 3c Heeft u tijdens uw WO-opleiding stage(s) gelopen in Nederland?

A 4 Zou u, achteraf bezien, de door u gevolgde WO-opleiding opnieuw kiezen?
VWO, HBS of gymnasium

HBO, namelijk:

anders, namelijk:

8 of hoger

7-8

lager dan 7

Studierichting (bv. economie):

Afstudeervariant (indien van toepassing) (bv. bedrijfseconomie, financiering):

voltijd-variant

deeltijd-variant

maand: jaar: $19 \ldots \ldots . . .$.

direct ingestroomd in de propedeuse behorend bij de eigen opleiding indirect ingestroomd via de propedeuse van een andere WO-opleiding, namelijk:

3 na de propedeuse ingestroomd op basis van een HBO-opleiding, namelijk:

4 na de propedeuse ingestroomd op basis van een ander voortraject, namelijk:

maand: jaar: $19 \ldots \ldots$. ja, namelijk:

nee

1 nee

2 ja, in totaal maximaal één jaar

3 ja, in totaal langer dan één jaar

1 ja

2 nee

1 ja

2 nee

ja, dezelfde WO-opleiding én aan de UM

ja, dezelfde WO-opleiding, maar aan een andere universiteit

nee, andere WO-opleiding, namelijk:

nee, opleiding buiten WO, namelijk:

nee, ik zou niet zijn gaan studeren (bv. direct zijn gaan werken) 
A 5a Heeft u ná uw WO-opleiding een andere opleiding gevolgd of voortgezet?

- géén cursus of bedrijfsopleiding.

- in geval van meerdere vervolgopleidingen, de volgens

$u$ belangrijkste vervolgopleiding.

A 5b Wanneer bent u met deze vervolgopleiding begonnen?

A 5c Volgt/Volgde u deze vervolgopleiding (overwegend) in voltijd of deeltijd?

A 5d Volgt u deze vervolgopleiding nog steeds? ja, namelijk AiO/OiO

ja, namelijk beurspromovendus

ja, namelijk lerarenopleiding

$4 \mathrm{ja}$, andere post-doctorale beroepsopleiding, namelijk: (bv. AGIO-kindergeneeskunde, accountant, rechter)

5 ja, andere opleiding, namelijk: (bv. WO: Sociologie, WO: Informatica; HBO: Bedrijfseconomie)

${ }^{6}$ nee $\rightarrow$ ga naar vraag $B 1$

maand: jaar: $19 \ldots \ldots . . .$.

voltijd

deeltijd

ja $\quad 2$ nee, voortijdig verlaten $\quad 3$ nee, inmiddels voltooid

\section{B. Cursussen/bedrijfsopleidingen}

B 1 Heeft u na het afstuderen in 1996/1997 cursussen en/of (bedrijfs)opleidingen gevolgd?

- niet de opleiding die $u$ eventueel al bij vraag A 5 heeft ingevuld

- geen hobbycursussen

B 2 Geef in onderstaand schema de volgens u belangrijkste cursus of (bedrijfs)opleiding aan die $u$ sinds het afstuderen in 1996/1997 heeft gevolgd.

Naam/beschrijving van cursus/(bedrijfs)opleiding

duur in weken

$$
\text { .......... weken }
$$

nee $\rightarrow$ ga naar vraag $B 8$

ja, één cursus/bedrijfsopleiding

$\mathrm{ja}$, ......... (aantal) cursussen/bedrijfsopleidingen

Let op: De vragen B $3 \mathrm{t} / \mathrm{m}$ B 7 hebben betrekking op

Wie verzorgt/verzorgde deze cursus of (bedrijfs)opleiding?
Welke van de volgende onderwerpen zijn behandeld in deze cursus of (bedrijfs)opleiding? - meerdere antwoorden mogelijk

Heeft $u$ deze cursus of (bedrijfs)opleiding gevolgd tijdens werkuren?

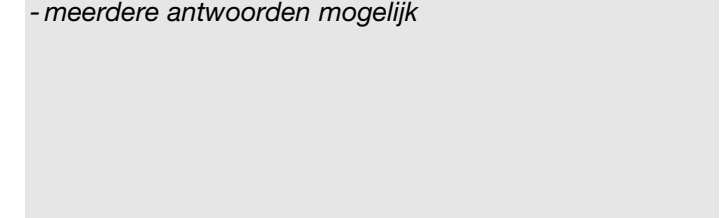

gemiddeld aantal contact- of lesuren per week ......... contact/lesuren per week 

1 om mijn tekort aan bepaalde kennis en vaardigheden weg te werken 2 om bij te blijven in mijn vakgebied (kennisveroudering tegengaan) 3 om mij verder te specialiseren in mijn vakgebied (kennisverdieping)

4 om door te kunnen stromen naar een andere/hogere functie (kennisverbreding)

5 verplicht gesteld door werkgever

6 anders, namelijk:

B 8 Heeft u op dit moment behoefte aan bijscholing?

nee

2 ja, behoefte aan bijscholing op de volgende gebieden:

1:

\section{Buitenlandervaring}

C 1 Heeft u vóór uw eerste inschrijving in het WO ooit in het buitenland gezeten voor werk of studie? - meerdere antwoorden mogelijk

C 2 Bent u tijdens uw WO-opleiding ooit in het buitenland geweest voor werk of studie?

C 3 Geef in onderstaande tabel de (maximaal twee) belangrijkste perioden aan die $u$ tijdens uw WO-opleiding in het buitenland heeft doorgebracht. (meerdere antwoorden mogelijk)

\section{A Land}

1

A Land

2

B Duur

...... maanden

\section{B Duur}

...... maanden
C 4 Heeft u sinds uw afstuderen in 1996/1997: - meerdere antwoorden mogelijk

\section{C hoofdactiviteit(en)}

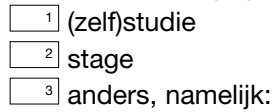

(..................................

\section{C hoofdactiviteit(en)}

1 (zelf)studie

2 stage

3 anders, namelijk: (land), voor jaren en maanden

evolgd in: (land), voor jaren en maanden

\section{D initiatiefnemer}

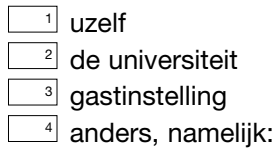

\section{D initiatiefnemer}

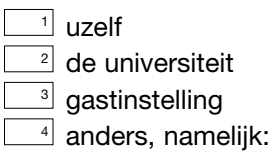

overwogen om in het buitenland te gaan werken? actief gezocht naar werk in het buitenland? een baan in het buitenland aangeboden gekregen? in het buitenland gewerkt?

5 buitenlandse reizen ondernomen in het kader van uw werk?
Hoe vaak heeft $u$ (mondeling of schriftelijk) contact met buitenlandse klanten of werkrelaties:
a. in het Nederlands?
b. in het Engels?
c. in het Frans?
d. in het Duits?
e. in een andere taal?

C 7 Welk percentage van uw totale werktijd brengt u ongeveer door in wat $u$ beschouwt als een internationale context? nee

2 ja, voor in totaal ....... weken

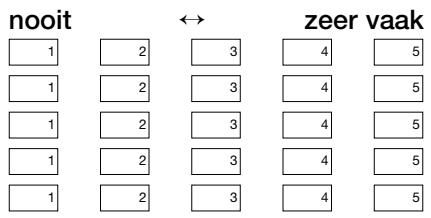

.......\% 
Hoe belangrijk vindt $u$ de volgende competenties voor uw werk?

a. professionele kennis van andere landen (bv. economie, wettelijke regelingen)

b. kennis/inzicht in verschillen in cultuur, levensstijl, gewoontes etc. in verschillende landen

c. goed kunnen samenwerken met mensen van verschillende culturele achtergronden

d. beheersing van vreemde talen helemaal niet belangrijk $\leftrightarrow$ zeer belangrijk

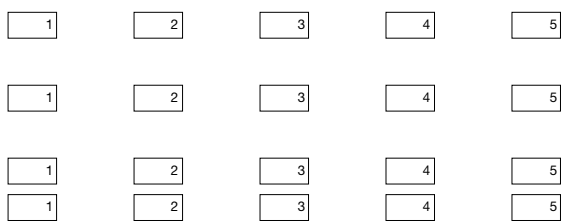

\section{Zoeken naar werk en loopbaan sinds afstuderen}

« De volgende vragen hebben betrekking op de periode ná afstuderen in 1996/1997

$\ll \quad B e s c h o u w$ een eventuele AIO/OIO plaats als betaald werk.

D 1 Heeft u na het afstuderen gezocht naar een betaalde baan? - exclusief zoeken naar bijbaantjes of vakantiewerk

D 2 Hoe heeft u gezocht naar de eerste betaalde baan na afstuderen?

D 3 Hoe belangrijk waren volgens $u$ de volgende selectiecriteria voor uw huidige werkgever om $\mathrm{u}$ in dienst te nemen?

a. opleidingsniveau

b. opleidingsrichting

c. hoofdvak/specialisatie

d. examencijfers

e. stage-ervaring

f. andere opgedane werkervaring

g. reputatie van de Universiteit Maastricht

h. buitenlandse ervaring

i. beheersing van vreemde talen

j. computervaardigheden

k. aanbevelingen/referenties van derden

I. persoonlijkheid

m. psychologische test/assessment center

n. anders, namelijk:

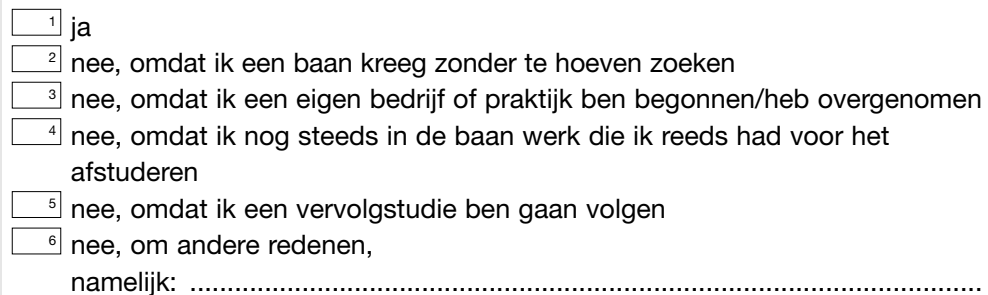

1 ik ben net zo lang blijven zoeken totdat ik een gewenste baan vond 2 ik heb er eerst voor gezorgd dat ik überhaupt een baan had, om van daaruit eventueel te gaan zoeken naar een meer gewenste baan

geheel onbelangrijk

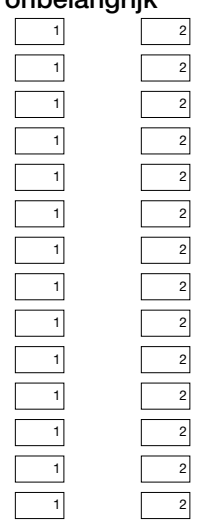

zeer

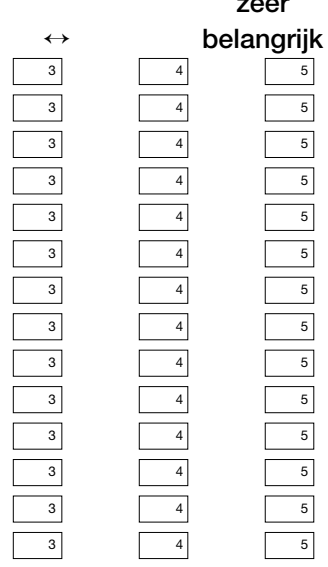

D 4a Via onderstaand schema willen wij iets meer te weten komen over de banen die u heeft gehad tussen afstuderen en het verkrijgen van uw huidige baan. Geef hierin aan, in chronologische volgorde, alle banen die u heeft gehad in deze periode.

Let op : - inclusief werk als zelfstandige/freelancer

- inclusief eerdere functies bij uw huidige werkgever

- banen mogen overlappen

1. Begindatum (maand/jaar)

2. (Indien geëindigd)

a. Einddatum (maand/jaar)

b. Heeft u vrijwillig ontslag genomen?

3. Vergeleken met vorige baan:

a. verandering van werkgever?

b. verandering van vakgebied?
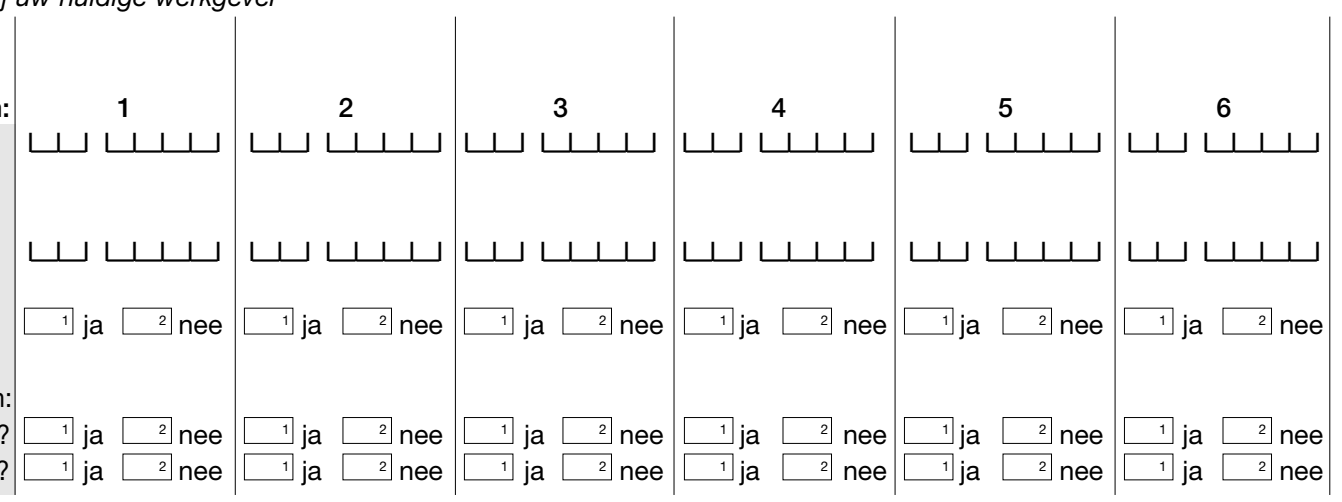


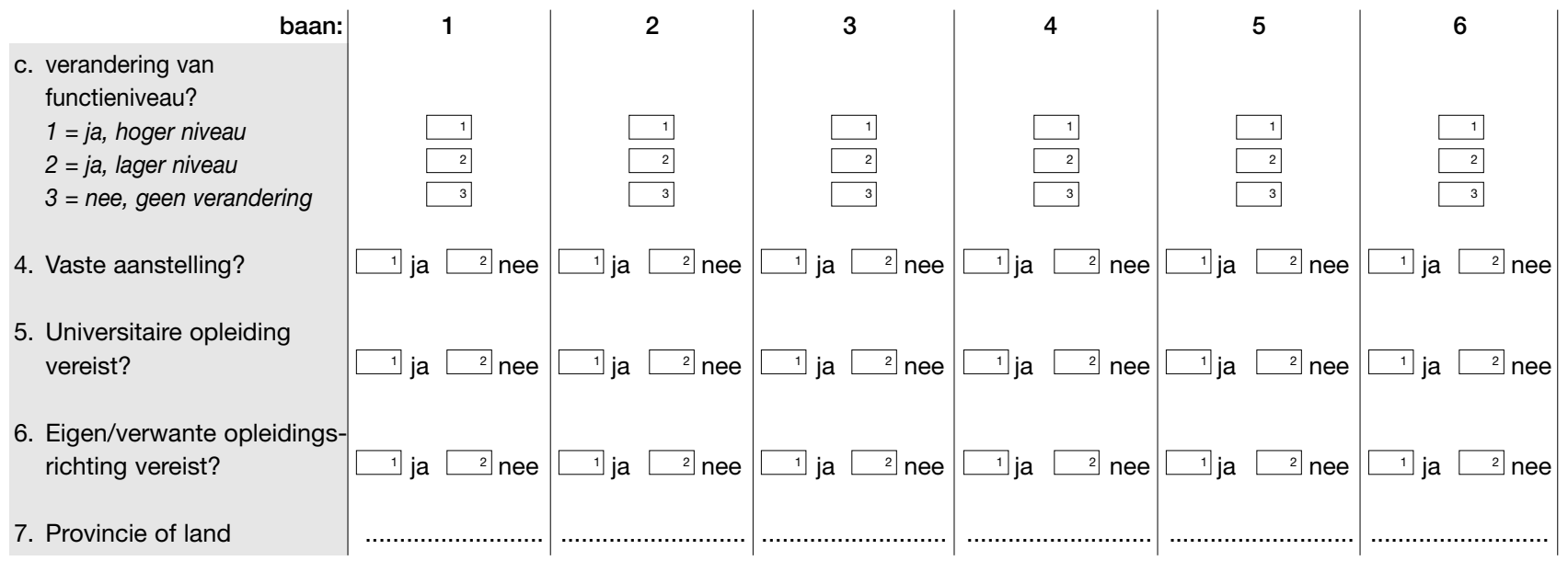

D 4b Geef in het onderstaand schema aan, in chronologische volgorde, alle perioden waarin u werkloos was en op zoek naar werk sinds uw afstuderen.

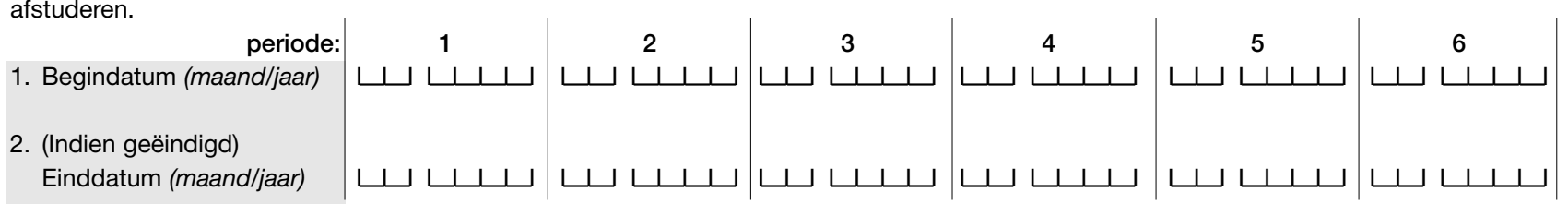

D 5a Welke omschrijving past volgens $u$ het beste bij uw huidige situatie?

D 5b Wanneer bent u begonnen met deze bezigheid?

betaald werk

2 studie

3 werkloos/werkzoekend

4 zorg voor kinderen/overige gezinsleden

5 anders, namelijk:

maand:

jaar

\section{E. Huidige werksituatie}

E 1a Heeft $u$ in de afgelopen vier weken iets gedaan om aan (ander) betaald werk te komen? (advertenties nakijken om een baan te vinden telt al mee)

E 1b Hoeveel uren per week zou u het liefst betaald werk willen hebben? (rekening houdend met gevolgen voor inkomenssituatie)

E 1c Stel, u vindt nú een (andere) baan. Hoe snel kunt $u$ daarmee dan beginnen?

E 1d Waarom kunt u niet eerder beginnen?

E 1e

Bent $u$ ingeschreven bij het arbeidsbureau/CWI?

E 2 Hoeveel werkgevers heeft $u$ in totaal gehad sinds uw afstuderen in 1996/1997?

- inclusief uzelf indien $u$ als zelfstandige/ freelancer heeft gewerkt

E 3 Heeft u op dit moment ook betaald werk? - een functie als AiO/OiO of beurspromovendus vatten we hier ook op als een betaalde baan.

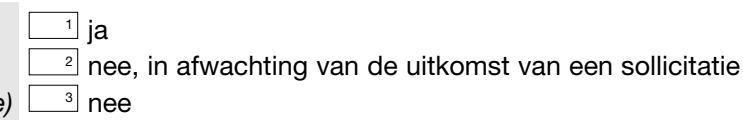

1 ik wil geen betaald werk $\rightarrow$ ga naar vraag $E 1 e$

2 ik wil betaald werk voor ............ uren per week

1 binnen 2 weken $\rightarrow$ ga naar vraag $E 1 e$

2 tussen twee weken en drie maanden

na 3 maanden

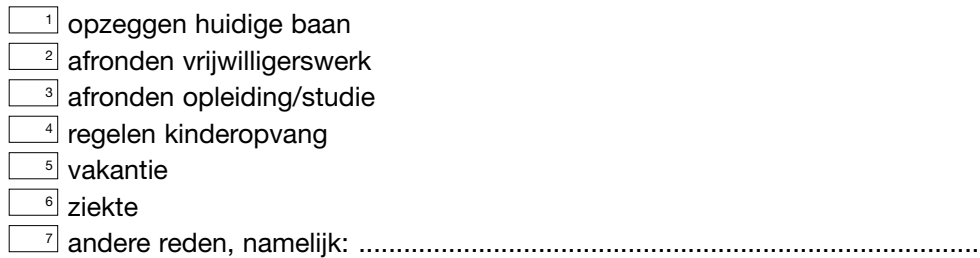

\section{1 ja \\ 2 nee}


E 4a Wanneer bent $u$ in deze baan begonnen? - als $u$ eerder een andere functie heeft vervuld voor dezelfde werkgever, geef de begindatum van de huidige functie aan.

E 4b Indien u een andere baan had vóór uw huidige functie, betekende uw huidige functie een:

a. verandering van werkgever?

b. verandering van vakgebied?

c. verandering van functieniveau?

E 5a Wat is de naam van uw huidige functie? (bv. fiscaal adviseur, AlO-openbare financiën, advocaat, gezondheidsvoorlichter, bedrijfsarts, AGNIO, beleidsmedewerker welzijn)

E 5b Wat zijn uw voornaamste werkzaamheden? (bv. testresultaten analyseren, diagnoses stellen, lesgeven, marketingplan opstellen)

E 6a In wat voor organisatie of bedrijf werkt u? (bv. academisch ziekenhuis, verpleeghuis, machinefabriek, bank, belastingkantoor, universiteit)

E 6b Wat voor soort product of dienst levert het bedrijf of de organisatie voornamelijk?

(bv. verpleging somatische patiënten, landbouwmachines, hypotheken, fiscaal advies, wetenschappelijk onderzoek)

E 6c Wat is de naam van het bedrijf of de organisatie?

E 6d Hoeveel mensen werken er bij de organisatie of het bedrijf waar $\mathrm{u}$ werkzaam bent?

- het gaat hier om alle werknemers van het totale concern (hoofd- en nevenvestigingen samen).

E 6e In welke plaats werkt u?

- het gaat hier om de vestiging waar $u$ zelf werkt. - werkt $u$ in het buitenland vermeld dan ook het land.

E 7 In welk dienstverband bent u werkzaam?

E 8 Wat voor aanstelling heeft $\mathrm{u}$ ?

Vul bij tijdelijk werk ook de totale duur van uw contract in.

Welk opleidingsniveau werd (door uw werkgever) voor deze functie minimaal vereist?

Welk opleidingsniveau past (volgens uzelf) het beste bij uw huidige werkzaamheden? maand: jaar:
1 persoon

2 - 9 personen

10 - 19 personen

20 - 49 personen

plaats:

land:

werkzaam als AiO/OiO

werkzaam als beurspromovendus

werkzaam als uitzend-, oproep- of invalkracht

in loondienst bij werkgever (anders dan categorie 1,2 of 3 )

free-lance

zelfstandige in eigen bedrijf

anders, namelijk:

(in proeftijd voor) vaste aanstelling/contract voor onbepaalde tijd

tijdelijke aanstelling van ........ maanden, met uitzicht op vaste aanstelling

tijdelijke aanstelling van ........ maanden, zonder uitzicht op vaste aanstelling

n.v.t., niet in loondienst

WO met postdoctorale opleiding WO

HBO met aanvullende opleiding

WO met postdoctorale opleiding WO

HBO met aanvullende opleiding
50 - 99 personen

100 - 499 personen

500 - 999 personen

1000 personen of meer 
E 10a Welke opleidingsrichting werd (door uw werkgever) voor deze functie vereist?

E 10b Welke opleidingsrichting past (volgens uzelf) het beste bij uw huidige werkzaamheden?

E 11 Waarom heeft $u$ een baan aangenomen die niet bij uw opleidingsrichting past?

- meerdere antwoorden mogelijk.

E 12 Aan hoeveel medewerkers geeft $u$ direct of indirect leiding?

E 13a Uit hoeveel uren per week bestaat een voltijdbetrekking bij uw bedrijf of organisatie? (indien $u$ als zelfstandige/freelance werkt: uren feitelijk gewerkt in een gemiddelde werkweek)

E 13b Heeft $\mathrm{u}$ in uw huidige functie een voltijdbetrekking? (indien in loondienst: ga uit van de omvang van uw arbeidscontract;

bij wisselende werkweken: een gemiddelde werkweek)

E 14 Wat is uw bruto maandinkomen in uw huidige (hoofd)functie?

- incl. provisie, toeslag ploegen/onregelmatige tijden.

- excl. overwerk, 13e maand, winstdeling, gratificaties, kinderbijslag, vakantiegeld, vergoeding reiskosten e.d. - excl. eventuele uitkering (RWW, WW, WAO e.d.).

- excl. inkomsten uit nevenfuncties.

- ga bij wisselende verdiensten uit van het gemiddelde.

E 15 Alle aspecten van uw huidige werk overziend, in welke mate maakt $u$ gebruik van de kennis en vaardigheden opgedaan tijdens de opleiding die u in 1996/1997 afsloot?

E 16a Heeft $u$ op dit moment nog één of meerdere betaalde nevenfunctie(s), naast de bij de vragen $\mathrm{E} 4 \mathrm{t} / \mathrm{m} \mathrm{E} 15$ beschreven baan?

E 16b Hoeveel uur per week werkt u over alle nevenfuncties gerekend?

- indien in loondienst: de omvang van uw arbeidscontract, bij wisselende werkweken: een gemiddelde werkweek. - excl. hoofdfunctie.

E 16c Hoeveel verdient $u$ in totaal bruto per maand in deze nevenfuncties?

- incl. provisie, toeslag ploegen/onregelmatige tijden.

- excl. overwerk, 13e maand, winstdeling, gratificaties, kinderbijslag, vakantiegeld, vergoeding reiskosten e.d. - excl. eventuele uitkering (RWW, WW, WAO e.d.).

- excl. inkomsten uit hoofdfunctie.

- ga bij wisselende verdiensten uit van het gemiddelde. uitsluitend mijn eigen opleidingsrichting

mijn eigen of een verwante opleidingsrichting

een geheel andere dan mijn opleidingsrichting

voor mijn baan maakt de opleidingsrichting niet zoveel uit

uitsluitend mijn eigen opleidingsrichting $\rightarrow$ ga naar vraag $E 12$

mijn eigen of een verwante opleidingsrichting $\rightarrow$ ga naar vraag $E 12$

een geheel andere dan mijn opleidingsrichting

voor mijn baan maakt de opleidingsrichting niet zoveel uit

ik ben er (nog) niet in geslaagd een passende baan te vinden

deze baan geeft betere carrièremogelijkheden

ik werk liever buiten mijn vakgebied

ik kreeg een promotie naar een baan buiten mijn vakgebied

ik kan meer verdienen in deze baan

ik heb meer werkzekerheid in deze baan

7 deze baan stelt mij in staat om in deeltijd of met flexibele werktijden te werken

8 ik heb een voorkeur voor deze regio

9 deze baan kan ik gemakkelijker verenigen met mijn gezinssituatie

10 anders, namelijk:

geen

aan ........... personen

uur per week

ja

nee, ik heb een aanstelling voor .........\%

bruto: Euro per maand

helemaal niet $\leftrightarrow$ in sterke mate

ja

nee $\rightarrow$ ga naar vraag $F 1$

uur per week

bruto: Euro per maand 


\section{F. Opleiding en Curriculum}

《< Deze vragen hebben betrekking op uw WO-opleiding, die u in 1996/1997 hebt afgerond.

F 1 Hieronder staat een aantal aspecten die in uw werk van belang kunnen zijn. Geef voor ieder aspect een inschatting van:

- (indien u werkt) het niveau dat vereist is in uw huidige functie;

- uw eigen niveau;

- waar $u$ het aspect vooral heeft geleerd

Kennis van:

1. uw eigen vakgebied (richting waarin $u$ bent afgestudeerd of waarin u een vervolgopleiding doet)

2. andere vakgebieden

Vermogen om:

3. vakkennis in de praktijk toe te passen

4. informatie te vergaren

5. problemen te analyseren en op te lossen

6. verbanden te leggen tussen verschillende zaken

7. hoofd- van bijzaken te onderscheiden

8. logisch te redeneren

9. conform budget en planning te werken

10. onder druk goed te functioneren

11. besluiten te nemen

12. nieuwe ideeën en oplossingen te bedenken

13. continue te leren

14. aan anderen duidelijk te maken wat $u$ bedoelt

15. met anderen samen te werken

16. leiding te geven

17. zelfstandig te werken

18. in conflictsituaties adequaat te reageren

19. presentaties te geven

20. gesprekken te voeren

21. rapporten en brieven te schrijven

22. in buitenlandse talen te communiceren

23. informatie- \& communicatietechnologie te gebruiken

Bereidheid om:

24. werkgerelateerde risico's te nemen

25. ideeën van uzelf en anderen ter discussie te stellen

26. op te komen voor uw eigen standpunt

27. begrip te tonen voor andere standpunten

28. verantwoordelijkheid te nemen

29. kritisch na te denken over uw eigen handelen

30. uw gedrag aan te passen aan de situatie

31. feedback te ontvangen en te geven

Afgestudeerden Economie en IB gelieve óók de aspecten $\mathbf{3 2}$ tot en met $\mathbf{3 6}$ in te vullen Vermogen om:

32. vakspecifieke technieken te gebruiken (boekhoudkundige software, statistische software, etc.)

33. vakspecifieke handelingen uit te voeren (marketing plan schrijven, organogram maken, financieringsplan opstellen, organisaties adviseren, onderhandelen met cliënten

34. om te gaan met verschillende culturen

35. bij economische/bedrijfskundige beslissingen, ethische en maatschappelijke aspecten te betrekken

36. een overzicht te hebben van de belangen van andere afdelingen/belanghebbenden
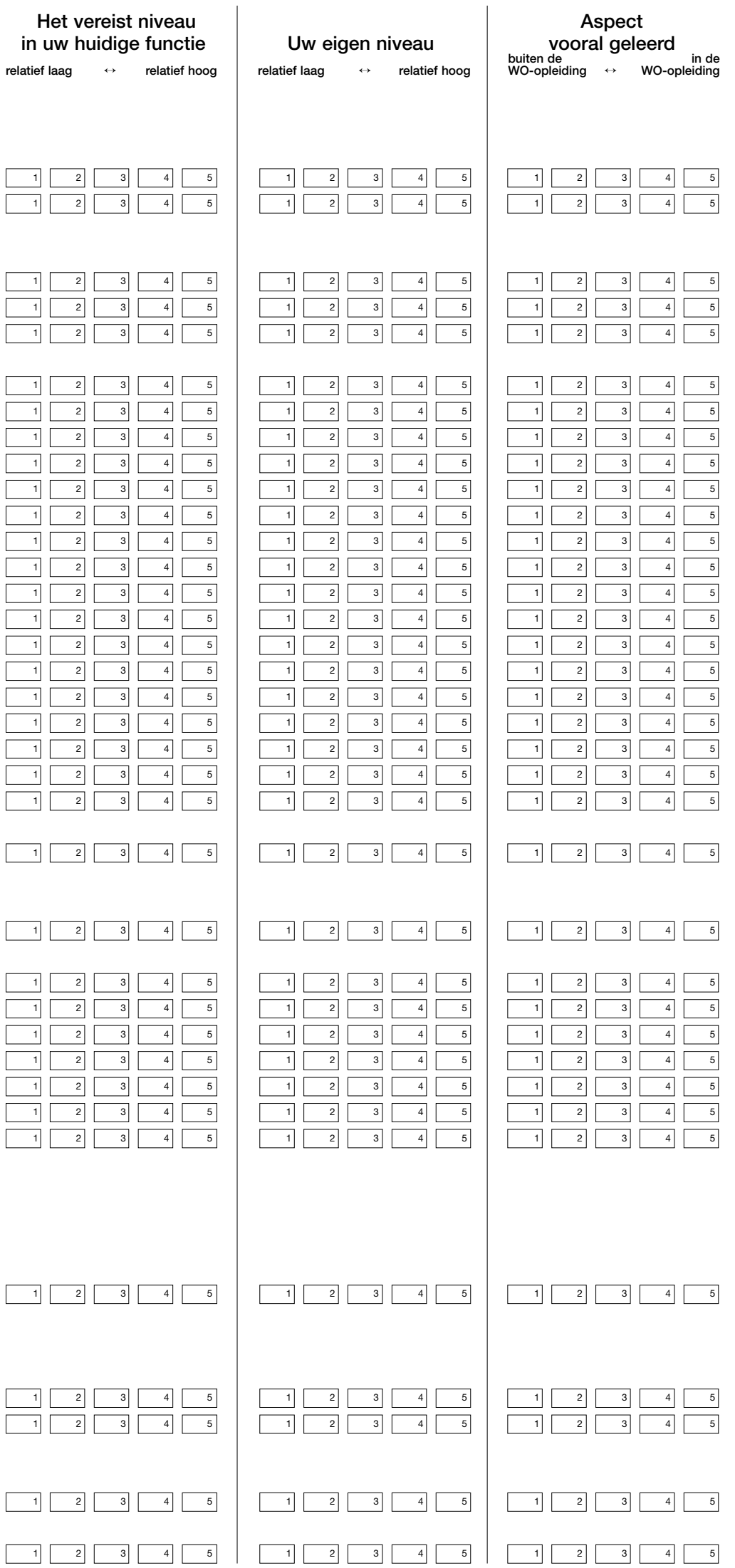
Afgestudeerden Geneeskunde gelieve óók de aspecten $\mathbf{3 7}$ tot en met $\mathbf{4 5}$ in te vullen Vermogen om:

37. diagnostische en therapeutische vaardigheden te verrichten

38. te communiceren met patiënten

39. op de hoogte te blijven van nieuwe medische ontwikkelingen

40. nieuwe medische inzichten te gebruiken

41. medische problemen op te lossen

42. het medisch handelen wetenschappelijk te onderbouwen

43. actief sturing te geven aan de professionele ontwikkeling

44. bij medische beslissingen de ethische en maatschappelijke aspecten te betrekken

45. de patiënt in relatie tot zijn omgeving te benaderen en te behandelen

Afgestudeerden Rechten gelieve óók de aspecten $\mathbf{4 6}$ tot en met $\mathbf{5 2}$ in te vullen

\section{Vermogen om:}

46. processtukken op te stellen (dagvaarding, conclusies)

47. een pleidooi te kunnen houden

48. een pleitnota te kunnen schrijven

49. relevante jurisprudentie op te zoeken, te interpreteren en toe te passen

50. te onderhandelen met wederpartij

51. besprekingen te voeren met cliënten

52. om te gaan met media

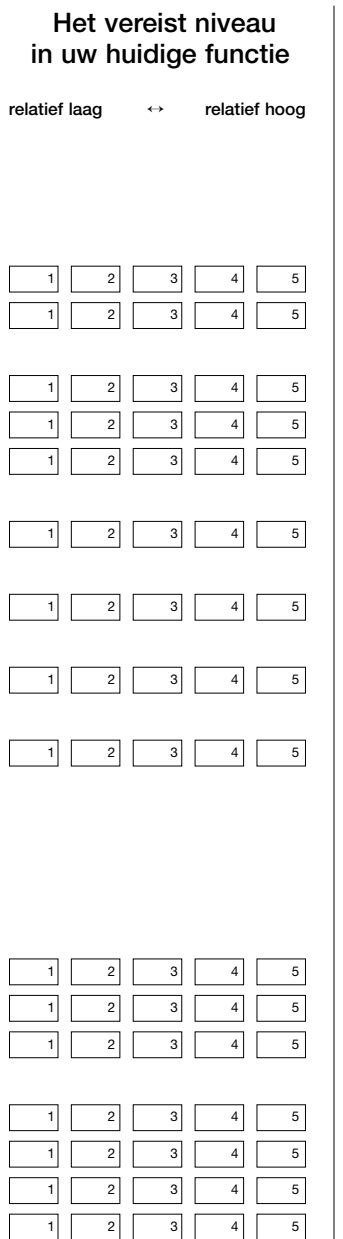

Uw eigen niveau

relatief laag $\leftrightarrow \quad$ relatief hoog

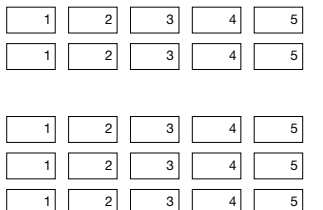

\begin{tabular}{|l|l|l|l|l|}
\hline 1 & 2 & & 3 & 4 \\
\hline
\end{tabular}
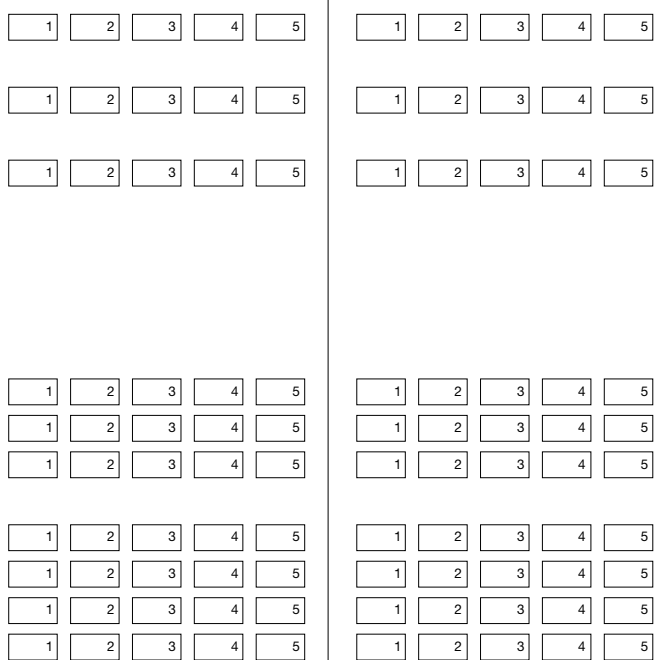

Aspect

buiten de vooral geleerd

wo-optiding in $\mathrm{d}$
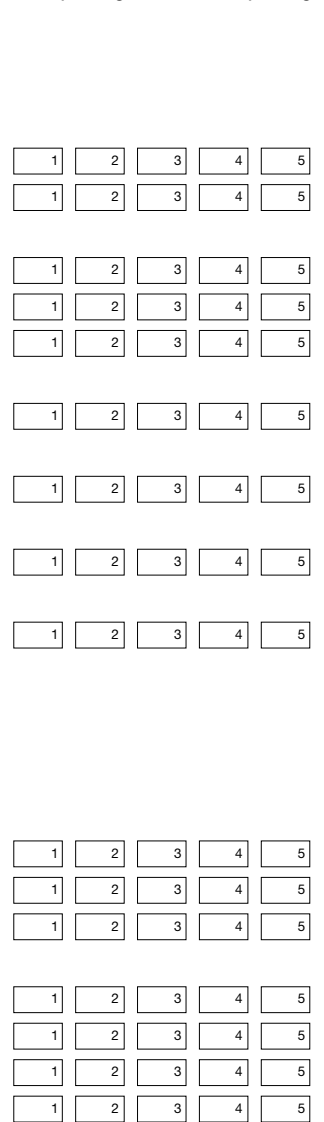

F 2 Noem maximaal 3 aspecten (uit de items 1-31 én uit de items die voor uw opleiding gelden) die in uw WO-opleiding:
a. te weinig aan bod zijn gekomen
b. te veel aan bod zijn gekomen

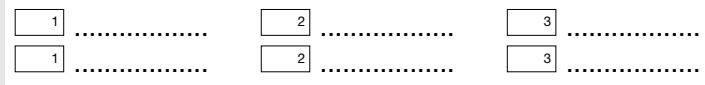

F 3 Alle aspecten overziend, hoe schat $u$ uw eigen niveau
in, in vergelijking met:
a. andere afgestudeerden van uw eigen WO-opleiding
b. alle afgestudeerde WO'ers?

F 4 Geef voor de onderstaande werkvormen aan:
a. hoeveel nadruk er op werd gelegd tijdens uw opleiding
b. of de opleiding volgens u minder, hetzelfde of meer nadruk er op zou moeten leggen

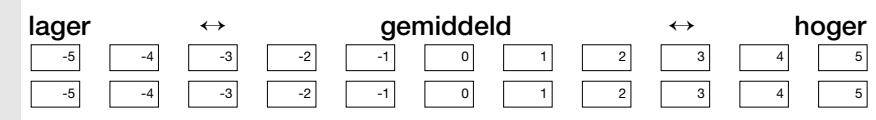

1. Onderwijsgroepen

2. Hoorcolleges

3. Groepsopdrachten

4. Vaardigheidstrainingen

5. Practica

6. Presentatie/voordracht

7. Computersimulaties/games

8. Schrijfopdrachten

9. Onderzoeksopdrachten

10. Patiëntencontacten

11. Anders, namelijk:

\section{Nadruk tijdens opleiding}

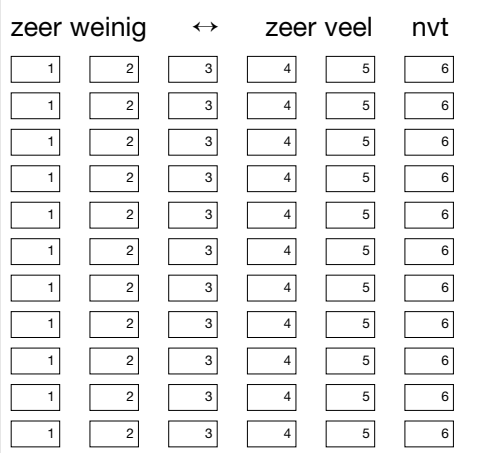

Nadruk gewenst

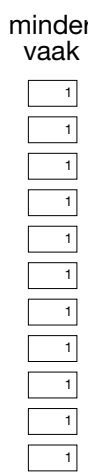

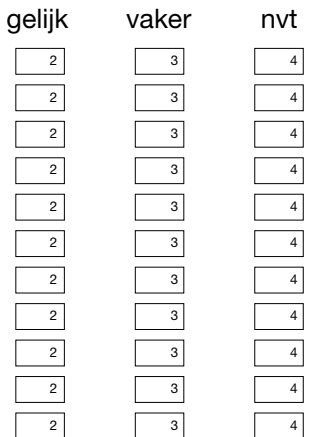


F 5 Aan de vaardigheden die ik tijdens de scriptie heb opgedaan, heb ik voldoende geleerd voor de praktijk.

F 6 Het schrijven van een scriptie geeft een duidelijke meerwaarde aan de opleiding.

F 7 Heeft u stage gelopen?

F 8 In de stage(s) heb ik voldoende geleerd voor de praktijk.

$\mathbf{F}$

Ik heb vaker stage willen lopen.

F 10 Het doen van een stage geeft een duidelijke meerwaarde aan de opleiding.

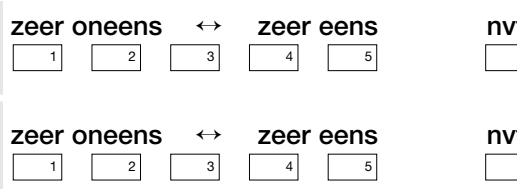

nvt

nvt

〉 Hieronder volgen enkele stellingen over de benodigde kennis en vaardigheden in de praktijk.

> Kunt $u$ aangeven in hoeverre $u$ het eens bent met deze stellingen.

F 11 Bij de overgang naar de beroepspraktijk heb ik tekorten ervaren in theoretische kennis.

F 12 Bij de overgang naar de beroepspraktijk heb ik tekorten ervaren in praktische vaardigheden.

F 13 Tijdens mijn opleiding ben ik voldoende in aanraking geweest met praktijkproblemen en praktijksituaties.

zeer oneens $\leftrightarrow$ zeer een

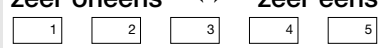

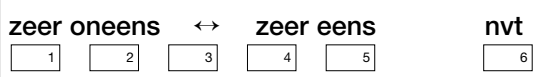

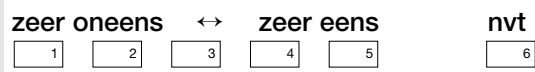

F 14 De kennis en vaardigheden die ik tijdens de opleiding heb verworven zijn voldoende om adequaat te starten in de beroepspraktijk.

F 15 De opleiding biedt voldoende basis voor het verder ontwikkelen van kennis en vaardigheden.

F 16 Nascholing is nodig vanwege tekortkomingen in mijn opleiding.

F 17 Nascholing is nodig om kennis en vaardigheden op te doen die beter te leren zijn in combinatie met werk.

F 18 Nascholing is nodig vanwege nieuwe ontwikkelingen die niet te voorzien waren tijdens mijn opleiding.$$
\text { ze }
$$
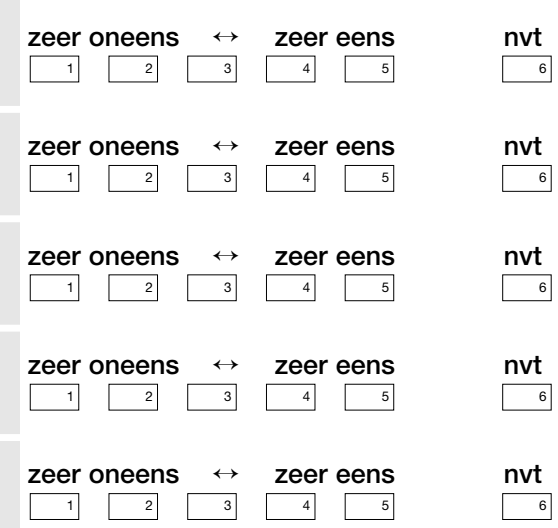

nvt

nvt

nvt

F 19 Ik ben over het algemeen tevreden over de wijze waarop zeer oneens $\leftrightarrow \quad$ zeer eens nvt de opleiding mij heeft voorbereid op de beroepspraktijk.

Bij de volgende stellingen is het de bedoeling dat $u$ aangeeft in hoeverre $u$ de opleiding op bepaalde aspecten zou willen veranderen. Hierbij kunt u op een schaal van 1 tot 7 aangeven in welke richting $u$ het betreffende opleidingsaspect wilt aanpassen. De waarde 4 kruist $u$ aan indien $u$ het opleidingsaspect niet wilt aanpassen.

Als ik de opleiding zou mogen aanpassen, dan gaat mijn voorkeur uit naar een:

breed programma

F 20b

F 20c

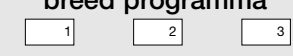

academisch programma

meer theorie neutraal

neutraal

neutraal specialistisch programma

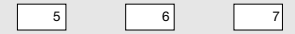

beroepsgericht programma

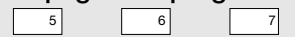

meer vaardigheden 
Als ik de opleiding zou mogen aanpassen, dan gaat mijn voorkeur uit naar een:

\begin{tabular}{|c|c|c|c|c|c|c|c|}
\hline \multirow[t]{2}{*}{ F 20d } & \multicolumn{3}{|c|}{ meer praktijkervaring } & neutraal & \multicolumn{3}{|c|}{ meer theorische vakken } \\
\hline & 1 & 2 & 3 & 4 & 5 & 6 & 7 \\
\hline \multirow[t]{2}{*}{ F 20e } & \multicolumn{3}{|c|}{ meer algemene vaardigheden } & neutraal & \multicolumn{3}{|c|}{ meer beroepsspecifieke vaardigheden } \\
\hline & 1 & 2 & 3 & 4 & 5 & 6 & 7 \\
\hline F $20 f$ & \multicolumn{3}{|c|}{ minder vrijheid bij vakkenkeuze } & neutraal & \multicolumn{3}{|c|}{ meer vrijheid bij vakkenkeuze } \\
\hline & 1 & 2 & 3 & 4 & 5 & 6 & 7 \\
\hline F $20 \mathrm{~g}$ & \multicolumn{3}{|c|}{ minder zwaar studieprogramma } & neutraal & \multicolumn{3}{|c|}{ zwaarder studieprogramma } \\
\hline & 1 & 2 & 3 & 4 & 5 & 6 & 7 \\
\hline \multirow[t]{2}{*}{ F $20 \mathrm{~h}$} & \multicolumn{3}{|c|}{ minder buitenland ervaring } & neutraal & \multicolumn{3}{|c|}{ meer buitenland ervaring } \\
\hline & 1 & 2 & 3 & 4 & 5 & 6 & 7 \\
\hline
\end{tabular}

\section{G. Werkoriëntaties en werksatisfactie}

G 1 Alle aspecten overziend, in welke mate bent $u$ tevreden met uw huidige baan?

G 2 Alle aspecten overziend, in welke mate voldoet uw huidige werksituatie aan de verwachtingen die $u$ had toen $u$ begon met uw WO-opleiding?

G 3 Hoe belangrijk waren/zijn de volgende levensdoelen voor u:
a. prestige
b. persoonlijke ontwikkeling
c. gevarieerd sociaal leven
d. thuis/gezin
e. geld verdienen
f. intellectuele verdieping
g. het hebben van werk

G 4 Hieronder staan een aantal aspecten van werk. Geef aan hoe belangrijk deze aspecten zijn voor u persoonlijk, en (indien u momenteel een baan heeft) in hoeverre ze op uw huidige werksituatie van toepassing zijn.

a. autonomie

b. wetenschappelijke verdieping

c. duidelijk gestructureerde werktaken

d. toepassing van kennis en vaardigheden

e. baanzekerheid

f. sociale status

g. inbreng van eigen ideeën

h. goede sfeer

i. mogelijkheden om bij te leren

j. hoog salaris

k. macht en invloed

I. uitdaging

m. carrièreperspectieven

n. genoeg tijd voor vrijetijdsbesteding

o. leidinggeven/coördinatie

p. werken in teamverband

q. maatschappelijk nut

r. afwisseling

s. mogelijkheden om werk en gezinstaken te combineren

zeer ontevreden $\leftrightarrow$ zeer tevreden

veel slechter veel beter

dan verwacht $\leftrightarrow$ dan verwacht

\begin{tabular}{llll}
\hline & 2 & 3 & 4
\end{tabular}

A. op het moment van studiekeuze?

$$
\text { geheel }
$$

onbelangrijk
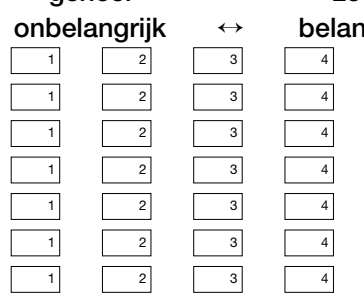

zeer

grijk

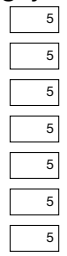

\section{A. belang}

geheel onbelangrijk

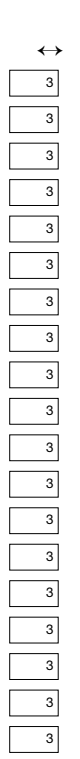

zeer

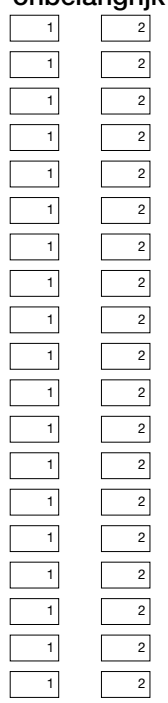

belangrijk

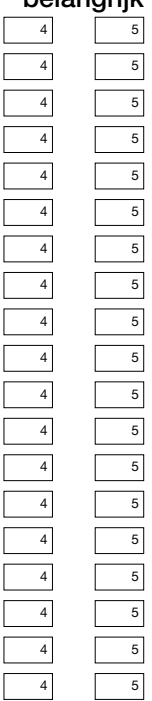

niet van toepassing

(ik had geen verwachtingen)

6

B. nu?

geheel zeer onbelangrijk $\leftrightarrow$ belangrijk

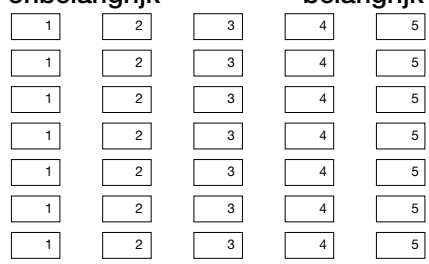

\section{B. van toepassing} op huidige werksituatie

helemaal niet $\leftrightarrow$ in sterke mate
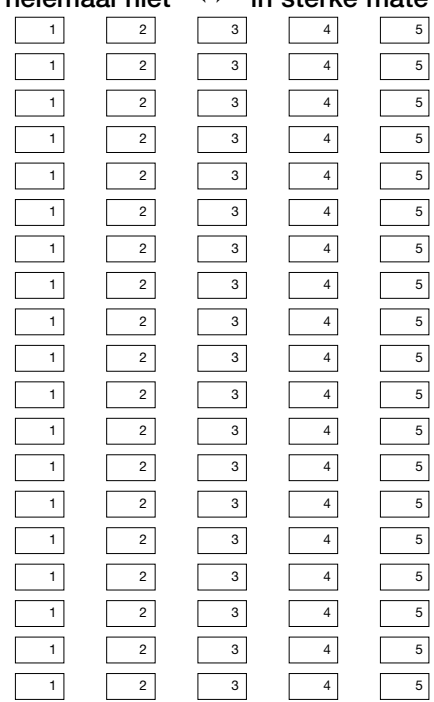


\section{H. Achtergrondgegevens}

H 1 Geslacht

1 man

2 vrouw

\section{H 2 Geboortejaar:}

H 3 Wat is het hoogst behaalde opleidingsniveau van uw (eventuele) partner?

$$
19 \ldots \ldots \ldots
$$

1 WO

2 HBO

$3 \mathrm{MBO}$

4 VWO, HBS of Gymnasium

5 HAVO of MMS

6 MAVO of lager

7 niet van toepassing

H 4a Hoe is uw huishouden samengesteld:

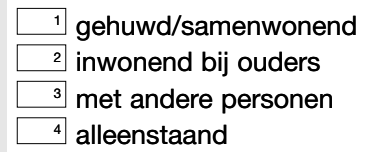

H 4b Sinds wanneer is uw huishouden zo samengesteld?

Sinds ................

H 5a Heeft u kinderen?

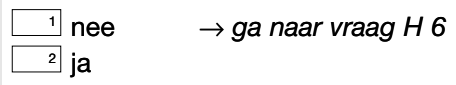

H 5b Hoeveel kinderen heeft u? kinderen

H 5c Wanneer is uw eerste kind geboren?

H 6 Hoeveel uren per week besteden u en uw eventuele partner gemiddeld aan huishoudelijke werkzaamheden?

H 7 Welke omschrijving past volgens u het beste bij de huidige situatie van uw eventuele partner?

In .

uzelf: ............ uren

uw partner: ............ uren

\section{Opmerkingen}

\section{Hartelijk dank voor het invullen!}

Stuur de vragenlijst zo snel mogelijk op in de antwoordenvelop (een postzegel is niet nodig). 
Bijlage 2 



\section{Vragenlijst voor werkgevers van alumni

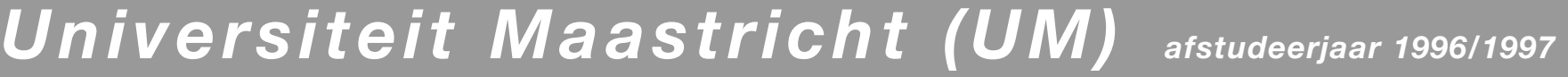

- Kruis steeds maar één antwoord aan, tenzij uitdrukkelijk anders is aangegeven.

- Antwoorden op open vragen op de stippellijntjes noteren.

1.

Wat is de naam van uw functie?

Functie:

$\gg>$

$\gg>$

Wilt $u$ bij het invullen van de rest van deze enquête uitgaan van de functie van de werknemer die $u$ deze enquête heeft gegeven.

2. Wat is de functie van de werknemer?

3. Welke specifieke opleiding heeft uw voorkeur voor de in vraag 2 aangegeven functie?
Functie:

1 de door de betreffende werknemer gevolgde opleiding

2 de door de betreffende werknemer gevolgde opleiding of een verwante opleiding

3 een andere specifieke opleiding, namelijk:

(bijvoorbeeld: WO economie: accountancy, HBO commerciële economie, WO bedrijfskunde, HBO informatica)

4 een opleiding op academisch niveau

5 een academische of $\mathrm{HBO}$-opleiding

6 anders, namelijk:

We leggen u nu een lijst met criteria voor die bij de selectie van nieuwe medewerkers een rol kunnen spelen. We vragen u een inschatting te maken van het belang van deze criteria bij de selectie voor de functie zoals in vraag 2 benoemd.
1. Opleidingsrichting
2. Opleidingsniveau
3. Specialisatie/hoofdvak
4. Examencijfers
5. Leeftijd
6. Stage ervaring
7. Bestuurservaring
8. Relevante werkervaring tijdens de eerder gevolgde opleiding
9. Relevante werkervaring na de opleiding
10. Relevante werkervaring binnen organisatie
11. Buitenlandervaring
12. Beheersing vreemde talen
13. Computervaardigheden
14. Reputatie universiteit
15. Activiteiten naast studie of werk
16. Persoonlijkheid
17. Extra genoten opleidingen, cursussen
18. Aanbevelingen derden
19. Psychologische test / assessment center
20. Anders, namelijk

4. Kunt $\mathrm{u}$ aangeven welke vijf criteria het zwaarst wegen bij de selectie van een nieuwe medewerker die de door $\mathrm{u}$ aangegeven functie zal gaan uitoefenen?

(u kunt volstaan met het invullen van de corresponderende nummers)
a.
b.
C.
d.
e. 
We leggen u nu een lijst met aspecten van werk voor. Wij willen u vragen met behulp van deze lijst een aantal selecties te maken. Wij vragen aan te geven welke voor $u$ de vijf belangrijkste aspecten zijn voor een goed functioneren in de functie, welke aspecten voor $u$ van belang zijn voor een verdere doorgroei binnen de organisatie en welke aspecten in het licht van de mogelijke recente ontwikkelingen in de functie het meest aan belang hebben gewonnen.

\section{Kennis van:}

1. het vakgebied van de medewerker

2. andere vakgebieden

\section{Vermogen om:}

3. vakkennis in de praktijk toe te passen

4. vakspecifieke technieken te gebruiken (boekhoudkundige software, statistische software, etc)

5. vakspecifieke handelingen uit te voeren (marketingplan schrijven, organogram maken, financieringsplan opstellen, organisaties adviseren, onderhandelen met cliënten, etc)

6. informatie te vergaren

7. problemen te analyseren en op te lossen

8. verbanden te leggen tussen verschillende zaken

9. hoofd- van bijzaken te onderscheiden

10. logisch te redeneren

11. conform budget en planning te werken

12. onder druk goed te functioneren

13. knopen door te hakken

14. nieuwe ideeën en oplossingen te bedenken

15. nieuwe dingen te leren

16. aan anderen duidelijk te maken wat je bedoelt

17. productief met anderen samen te werken

18. capaciteiten van anderen aan te spreken

19. leiding te geven

20. zelfstandig de werkzaamheden uit te voeren

21. presentaties te geven

22. gesprekken te voeren

23. rapporten en brieven te schrijven

24. in buitenlandse talen te communiceren

25. informatie- en communicatietechnologie te gebruiken

\section{Bereidheid om:}

26. werkgerelateerde risico's te nemen

27. ideeën van jezelf en anderen ter discussie te stellen

28. op te komen voor je eigen standpunt

29. begrip te tonen voor andere standpunten

30. verantwoordelijkheid te nemen

31. na te denken over je eigen handelen

32. je gedrag aan te passen aan de situatie

33. feedback te ontvangen en te geven

5. Zou u uit bovenstaande lijst de vijf belangrijkste aspecten kunnen noemen die voor $u$ het belangrijkst zijn met het oog op het goed kunnen functioneren in de door $u$ aangegeven functie? (u kunt volstaan met het invullen van de corresponderende nummers)
a.
b.
c.
d.
e.

6. Zou u uit bovenstaande lijst de vijf belangrijkste aspecten kunnen noemen die belangrijk zijn om (op termijn) verder door te kunnen groeien binnen uw organisatie?

(u kunt volstaan met het invullen van de corresponderende nummers)

7. Zou u uit bovenstaande lijst de vijf belangrijkste aspecten kunnen noemen die in het licht van de mogelijke recente ontwikkelingen in de functie het meest aan belang hebben gewonnen? (u kunt volstaan met het invullen van de corresponderende nummers)
a. .
b.
c.
d. .
e. ……………………………

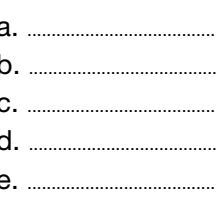

a.

b. .

c. .

e. 
8. Vervolgens willen we u vragen naar uw oordeel over de opleiding die de werknemer gevolgd heeft en zoals $u$ die in vraag 4 benoemd heeft. Geef op een schaal van 1 tot 5 aan in hoeverre $\mathrm{u}$ het met de volgende stellingen eens bent.

a. de kennis en vaardigheden die tijdens de opleiding zijn verworven zijn voldoende om deze functie adequaat uit te oefenen.

b. de opleiding biedt voldoende basis voor het verder ontwikkelen van kennis en vaardigheden voor een verdere carrière.

c. Nascholing is nodig vanwege tekortkomingen in de opleiding.

d. Nascholing is nodig om kennis en vaardigheden op te doen die beter te leren zijn in combinatie met werk.

e. Nascholing is nodig vanwege ontwikkelingen die niet te voorzien waren tijdens de opleiding.

f. Ik ben over het algemeen tevreden over de wijze waarop de opleiding heeft voorbereid op de arbeidsmarkt.
Oneens

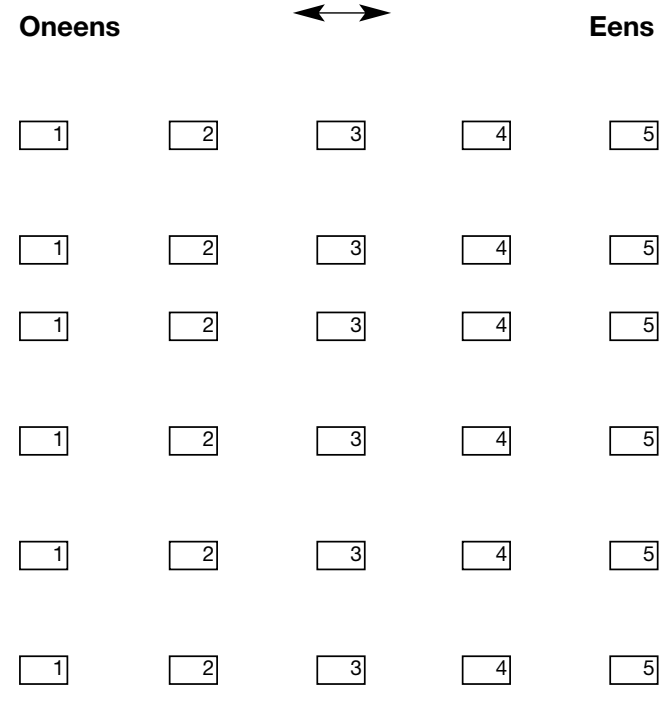

9. We willen u nog een paar stellingen over de opleiding voorleggen. Het gaat hierbij om uw voorkeur ten aanzien van de opleiding die de werknemer voor de betreffende functie gevolgd heeft. Bij de stellingen is het de bedoeling dat $u$ aangeeft in hoeverre $u$ de opleiding op bepaalde aspecten zou willen veranderen. Kunt $u$ op een schaal van 1 tot 5 aangeven in welke richting $u$ het betreffende opleidingstraject wilt aanpassen? De waarde 3 kruist $u$ aan wanneer $u$ het opleidingstraject niet wilt aanpassen.

a. Als ik de opleiding zou mogen aanpassen, dan gaat mijn voorkeur uit naar een:

b. Als ik de opleiding zou mogen aanpassen, dan gaat mijn voorkeur uit naar een:

c. Als ik de opleiding zou mogen aanpassen, dan gaat mijn voorkeur uit naar:

d. Als ik de opleiding zou mogen aanpassen, dan gaat mijn voorkeur uit naar:

e. Als ik de opleiding zou mogen aanpassen, dan gaat mijn voorkeur uit naar:

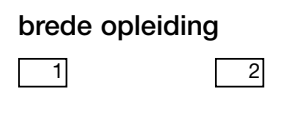

academische opleiding

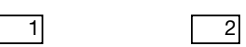

meer theorie

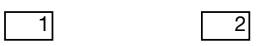

meer algemene vaardigheden<smiles>C1=CC=C1</smiles>

\section{2}

meer theoretische kennis
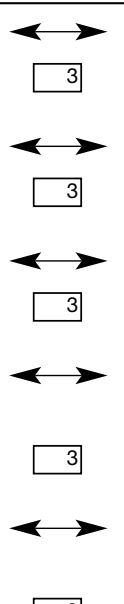

specialistische opleiding<smiles>C1=CCC1</smiles>

beroepsgerichte opleiding

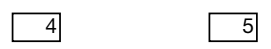

meer vaardigheden

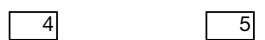

meer beroeps-

specifieke vaardigheden

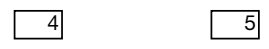

meer praktijk-

ervaring

\begin{tabular}{|l|l|l|l|}
\hline 1 & 2 & 4 & 5 \\
\hline
\end{tabular}

\section{Opmerkingen}

Hartelijk dank voor het invullen! Stuur de vragenlijst zo snel mogelijk op in de antwoordenvelop (een postzegel is niet nodig). 
